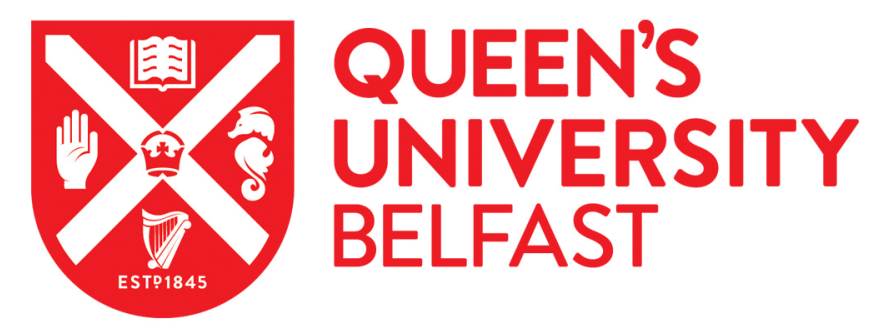

\title{
Glacial cirques as palaeoenvironmental indicators: their potential and limitations
}

Barr, I. D., \& Spagnolo, M. (2015). Glacial cirques as palaeoenvironmental indicators: their potential and limitations. Earth-Science Reviews, 151, 48-78. https://doi.org/10.1016/j.earscirev.2015.10.004

\author{
Published in: \\ Earth-Science Reviews
}

\section{Document Version:}

Peer reviewed version

\section{Queen's University Belfast - Research Portal:}

Link to publication record in Queen's University Belfast Research Portal

\section{Publisher rights}

(O2015 Elsevier. This manuscript version is made available under the CC-BY-NC-ND 4.0 license http://creativecommons.org/licenses/by-nc$\mathrm{nd} / 4.0 /$ which permits distribution and reproduction for non-commercial purposes, provided the author and source are cited.

\section{General rights}

Copyright for the publications made accessible via the Queen's University Belfast Research Portal is retained by the author(s) and / or other copyright owners and it is a condition of accessing these publications that users recognise and abide by the legal requirements associated with these rights.

Take down policy

The Research Portal is Queen's institutional repository that provides access to Queen's research output. Every effort has been made to ensure that content in the Research Portal does not infringe any person's rights, or applicable UK laws. If you discover content in the Research Portal that you believe breaches copyright or violates any law, please contact openaccess@qub.ac.uk. 


\title{
Glacial cirques as palaeoenvironmental indicators: their potential and limitations
}

\author{
lestyn D. Barr (Corresponding author) \\ School of Geography, Archaeology and Palaeoecology, Queen's University Belfast, BT7 1NN, Belfast, UK \\ Email: i.barr@qub.ac.uk
}

Tel: +44 (0)2890975146

\section{Matteo Spagnolo}

School of Geosciences, University of Aberdeen, Elphinstone Road, AB243UF, Aberdeen, UK

\begin{abstract}
Glacial cirques are armchair-shaped erosional hollows, typified by steep headwalls and, often, overdeepened floors. They reflect former regions of glacier initiation, and their distribution is, therefore, linked to palaeoclimate. Because of this association, cirques can be analysed for the information they provide about past environments, an approach that has a strong heritage, and has seen resurgence over recent years. This paper provides a critical assessment of what cirques can tell us about past environments, and considers their reliability as palaeoenvironmental proxies. Specific focus is placed on information that can be obtained from consideration of cirque distribution, aspect, altitude, and morphometry. The paper highlights the fact that cirques potentially provide information about the style, duration and intensity of former glaciation, as well as information about past temperatures, precipitation gradients, cloud-cover and wind directions. In all, cirques are considered a valuable source of palaeoenvironmental information (if used judiciously), particularly as they are ubiquitous within formerly glaciated mountain ranges globally, thus making regional or even global scale studies possible. Furthermore, cirques often occupy remote and inaccessible regions where other palaeoenvironmental proxies may be limited or lacking.
\end{abstract}

"Custom has not yet made a decision as to the universal name of this feature of mountain sculpture. Many countries furnish their own local names, and the word has been parenthetically translated into three or four languages [...]. In the Scottish Highlands, corry is the prevailing word; in Wales, cwm; in Norway, botn; in the Alps, kar; while the French-Swiss supply the name cirque" (Brown, 1905, p. 87)

\section{Introduction}

Glacial cirques (hereafter 'cirques') are armchair-shaped hollows typically found in upland settings, and largely owe their shape to erosion by relatively small (cirque type) glaciers. Cirques have been the focus of research for over 150 years (e.g., Darwin, 1842; Tyndall, 1862; Gastaldi, 1873), and the past decade has seen a resurgence of interest in their analysis (e.g., Evans, 2006a; Delmas et al., 2015; Mitchell and Humphries, 2015). A number of studies have focused on understanding the mechanisms and processes responsible for cirque formation, by establishing what accounts for their distribution and characteristic morphology (e.g., Graf, 1976; Gordon, 1977; Jansson et al., 1999). A byproduct of these studies is that cirque morphology and distribution have been discovered to reflect not only the general geology and topography of a region, but also specific palaeoenvironmental conditions. In particular, cirques can provide quantitative and qualitative information about the characteristics of past glaciers and climates (e.g., Hughes et al., 2007; Mîndrescu et al., 2010).

Cirques reflect former regions of glacier initiation, and their distribution is, therefore, linked to palaeoclimate. Cirque dimensions are a reflection of the intensity of former glacial erosion and periglacial weathering, and can, again, be linked to palaeoclimate (Evans, 2006b). As palaeoenvironmental proxies, cirques are particularly useful for regional, continental and, arguably, planet-wide studies because they are ubiquitous in regions of former glacier initiation. Cirques also often occupy remote and inaccessible regions, where other palaeoenvironmental proxies may be limited or lacking (Barr and Spagnolo, 2013).

Renewed interest in cirques over recent decades is not only a reflection of their importance as palaeoenvironmental proxies, but also stems from the fact that they represent one of the most striking indicators of how glaciers (and therefore climate) can limit the growth of mountains at a global scale (e.g., Mitchell and Montgomery, 2006; Egholm et al., 2009)-making cirques key to understanding many interactions between glaciers, climate and topography (Anders et al., 2010; Mîndrescu and Evans, 2014). This recent interest has been facilitated by the development of remote sensing and Geographical Information System (GIS) techniques, which allow the mapping and analysis of cirques in ways and numbers that were impossible (or at least very impractical) 20 years ago (Federici and Spagnolo, 2004; Principato and Lee, 2014). Given this recent interest, the aim of this paper is to provide a critical review of what cirques can tell us about past environments, and to assess their utility as palaeoenvironmental proxies. Such a review is currently lacking, despite extensive work on the description and significance of cirques. The focus is specifically on the information that can be derived from cirques themselves, rather from the sediments they contain (though such sediments can serve as vital palaeoenvironmental records-e.g., Fey et al., 2009). The paper is primarily a review of published material (more than 200 papers) written in English (with a few exceptions), and includes (i) an introduction to cirques, their initiation and development; and (ii) a review of the ways in which cirques are used as indicators of past environments.

It is important to stress that although palaeoenvironmental conditions are a key control on the morphology and distribution of cirques, other background conditions also influence the present day characteristics of these landforms. These conditions include the geology of the underlying bedrock (Haynes, 1968; Walder and Hallet, 1986), the nature of the weathering and erosional processes that have operated after deglaciation (Shakesby and Matthews, 1996; Gordon, 2001; Bathrellos et al., 2014), and the number and statistical significance of the landform populations found in various regions (Evans, 1994; Sauchyn et al., 1998; Hughes et al., 
2007). This study's focus on the role of palaeoenvironmental conditions does not underplay the important role of these processes in controlling cirque form and distribution, but is simply an attempt to provide a state of the art review of the way in which the glacial community has used these landforms to understand past climatic conditions. The range of "nonpalaeoenvironmental" factors and their potential influence on cirque morphology are discussed in the latter part of this paper, in

section that considers the limitations of using cirque landforms as a mechanism for palaeoenvironmental reconstruction. The paper then concludes by discussing directions and agendas for future research.

\section{Cirque properties}

\subsection{Cirque definition}

A cirque, as defined by Evans and Cox (1974, p. 151), is "a hollow, open downstream but bounded upstream by the crest of a steep slope ('headwall') which is arcuate in plan around a more gently-sloping floor. It is glacial if the floor has been affected by glacial erosion while part of the headwall has developed subaerially". In addition, Evans and Cox (1974) suggested that, for a landform to be defined as a cirque, at least part of the floor should be gentler than $20^{\circ}$, and some of the headwall should be steeper than the main angles of talus (i.e., $\left.31-36^{\circ}\right)$. In planform (i.e., when viewed from above), cirques are typically arcuate, with lateral spurs sometimes curving inwards down valley (Fig. 1). In profile (i.e., when viewed in cross section), cirques typically show a transition from a steep headwall (backwall) to a shallow, flat or overdeepened floor below (Fig. 2), often occupied by a lake or bog (Fig. 1). These lakes facilitate cirque identification, particularly when viewed from aerial photographs and satellite images, and can preserve vital palaeoenvironmental records (e.g., Fey et al., 2009). At their downvalley extents, cirques often have a reverse bed slope, leading to a 'lip' or 'threshold' (a convex break of slope separating the cirque from the valley below), sometimes occupied by a frontal moraine (Fig. 2). Because of their topographic setting, and armchair-shaped (concave) morphology (Fig. 1c), cirques act as traps for snow and ice, meaning that pre-existing cirques are often the first places to be occupied during the onset of glaciation, and the last places to be deglaciated during termination (Graf, 1976).
Though they can have characteristic morphology (as outlined above), cirques are complex features, and range significantly in their overall form (from circular to rectilinear; from overdeepened to outward-sloping) (Fig. 3). Because of this complexity, cirques are typically classified according to their 'degree of development', as reflected by their morphology. A number of classification systems have been proposed (e.g., de Martonne, 1901; Rudberg, 1952; Vilborg, 1984), but the most widely used is presented by Evans and Cox (1995), who categorise cirques according to the following grades: grade 1'classic' cirques, with all textbook attributes (e.g., Fig. 3a); grade 2-'well-defined' cirques, where the headwall and floor are clearly developed, and the headwall curves around the floor (e.g., Fig. 3b); grade 3-'definite' cirques, where there is no debate over cirque status, but one characteristic may be weak (e.g., Fig. 3c); grade 4-'poor' cirques, where there is some doubt about cirque status, but well-developed characteristics compensate for weak ones (e.g., Fig. 3d); and grade 5-'marginal' cirques, where cirque status and origin are doubtful (e.g., Fig. 3e).

As well as classifying cirques according to 'grade', a distinction is often made between different cirque 'types' (e.g., Gordon, 1977; Benn and Evans, 2010). These include: (i) 'Simple cirques', which are distinct, independent features (e.g., Fig 4a); (ii) 'compound cirques', where the upper part of a large cirque basin consists of two simple cirques of approximately equal size (e.g., Fig. 4b); (iii) 'cirque complexes', where the upper part of a large cirque basin consists of more than two subsidiary cirques (e.g., Fig. 4c); (iv) 'staircase cirques', where two or more cirques occur one above the other (e.g., Fig. 4d); and (v) 'cirque troughs', where the cirque marks the upper end of a glacial trough (e.g., Fig. 4e). Other classification schemes also exist, for example Delmas et al. (2015) differentiate between elementary first-order cirques; second-order (cirques-in-cirques); and third-order cirques (cirques-in-cirques-in-cirques). In reality, these classifications are overly simplistic, and cirques can have attributes of more than one group. There is also some dispute about whether each of these categories exists. For example, Mîndrescu and Evans (2014) avoid recognition of staircases of more than two cirques (i.e., 'cirques-in-cirques-in-cirques'), suggesting that the third floor down in such a sequence is typically a valley-step, rather than a cirque floor.
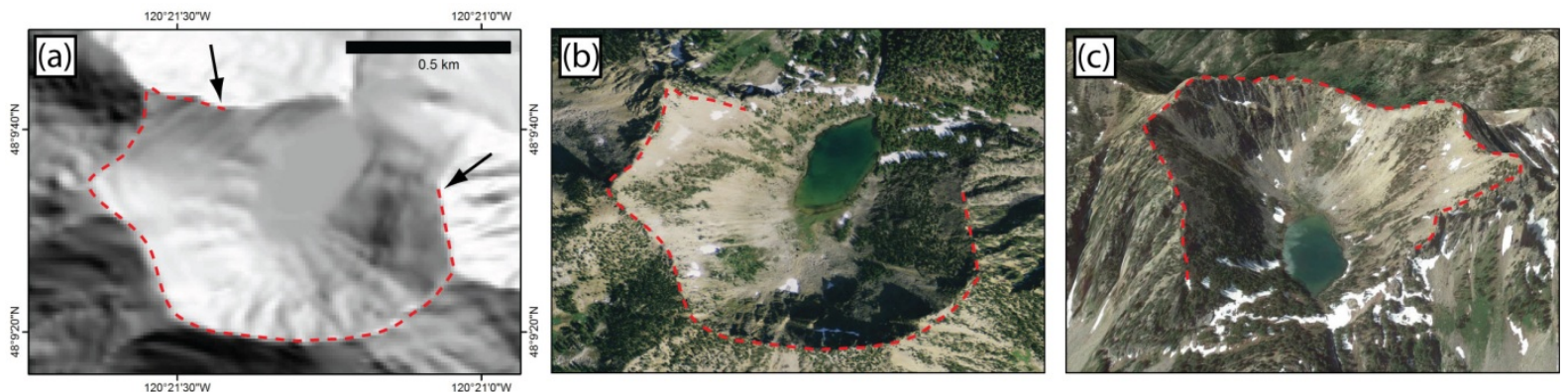

Fig. 1. Plan morphology of Sunrise Lake Cirque $\left(48.160^{\circ} \mathrm{N}, 120.354^{\circ} \mathrm{W}\right)$, Washington, USA, viewed (a) in a relief shaded USGS National Elevation Database (NED) 10 m DEM, and (b) in a Bing ${ }^{\text {TM }}$ aerial image. (c) Oblique Google Earth ${ }^{\mathrm{TM}}$ image, viewed from the North. Arrows in (a) highlight lateral spurs. 


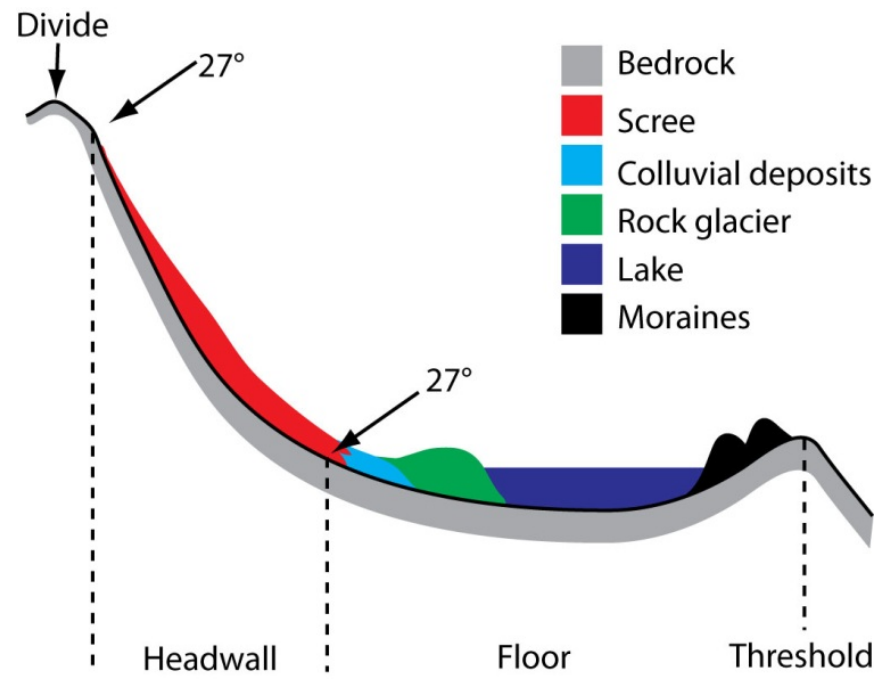

Fig. 2. Schematic cross section of a 'textbook' cirque, displaying a cirque divide (upper limit), a steep headwall ( $\left.>27^{\circ}\right)$, a shallow cirque floor $\left(<27^{\circ}\right)$, and a cirque threshold. Note that not all described geomorphological features are present in every cirque. Figure based on Seijmonsbergen et al. (2014).
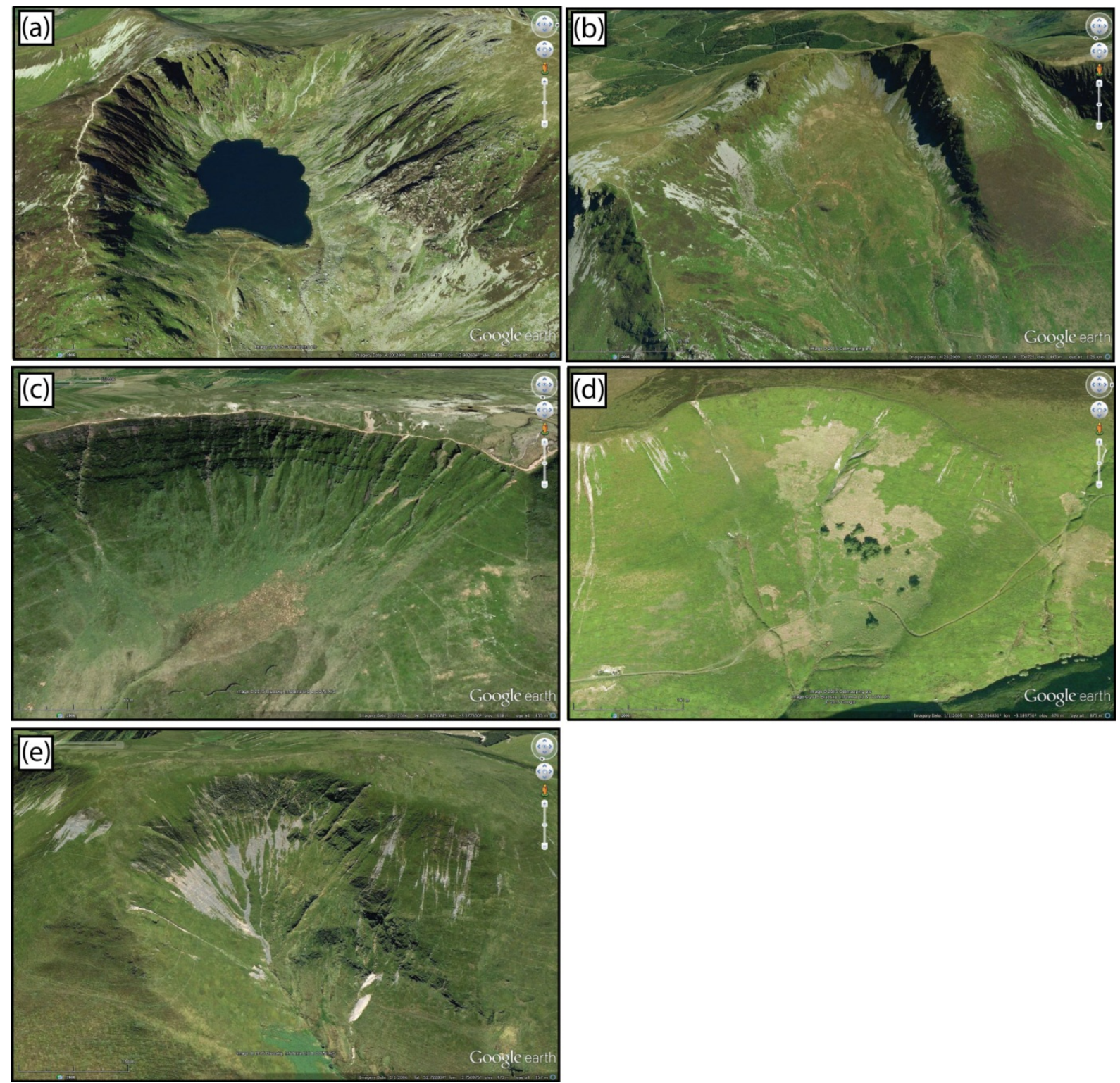

Fig. 3. Oblique Google Earth ${ }^{\mathrm{TM}}$ images showing examples (from Wales) of different cirque grades (grades are explained in section 2.1.). (a) Grade 1: Cwm Cau $\left(52.693^{\circ} \mathrm{N}, 3.902^{\circ} \mathrm{W}\right)$, a classic cirque on the flanks of Cadair Idris, west Wales. (b) Grade 2: Craig Trum y Ddysgl $\left(53.046^{\circ} \mathrm{N}, 4.170^{\circ} \mathrm{W}\right)$, a well-defined cirque above Nantlle, NW Wales. (c) Grade 3: Cwm Cwareli $\left(51.875^{\circ} \mathrm{N}, 3.376^{\circ} \mathrm{W}\right)$, a definite cirque in the Brecon Beacons, south Wales. (d) Grade 4: a poor cirque $\left(52.264^{\circ} \mathrm{N}, 3.192^{\circ} \mathrm{W}\right.$ ) in the Radnor Forest, east Wales. (e) Grade 5 : 
Craig Rhiw-erch $\left(52.722^{\circ} \mathrm{N}, 3.750^{\circ} \mathrm{W}\right)$, a marginal cirque in the Corris group, west Wales. Classifications are based on Evans (2006a), using the Evans and Cox (1995) cirque classification scheme.

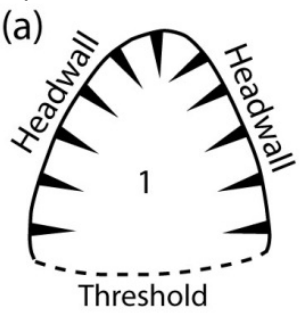

(d)

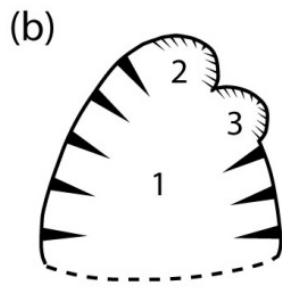

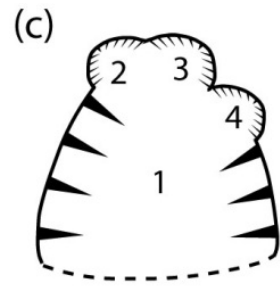

(e)
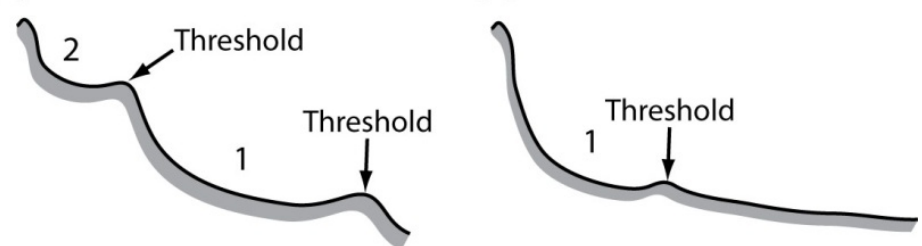

Fig. 4. Schematic illustration of different cirque types. (a) Planimetric view of a Simple cirque (1), which is a distinct, independent feature. (b) Planimetric view of a compound cirque, where the upper part of a large cirque basin (1) consists of two simple cirques (2 and 3) of approximately equal size. (c) Planimetric view of a cirque complex, where the upper part of a large cirque basin (1) consists of more than two subsidiary cirques (2, 3 and 4). (d) Profile view of staircase cirques, where one cirque (2) occurs above another (1). (e) Profile view of a cirque trough (1), where the cirque marks the upper end of a glacial trough.

\subsection{Cirque initiation and development}

Discussion and debate about the precise mechanisms responsible for the initiation and development of glacial cirques has been long-lasting, and remains a topic of uncertainty (Evans, 2008; Turnbull and Davies, 2006). Several schemes have been proposed (e.g., Gordon, 1977; Bennett, 1990; Brook et al., 2006), and the prevailing view is that cirques initially form through the enlargement of pre-existing mountainside hollows of various origins (fluvial, volcanic, mass-movement) (Haynes, 1998; Evans 2006a). Where local topoclimatic conditions allow (i.e., where altitude, orientation, and regional climate are favourable), these mountainside hollows can become occupied by perennial snow and ice (Sanders et al., 2013). At this time, hollows can start to enlarge by nivation (i.e., a range of weathering and mass wasting processes associated with perennial snow) (Thorn, 1976, 1988). Cirque development only occurs when snow thickness within hollows increases to a point where compaction and metamorphosis (closing air-filled pores, and increasing bulk density) lead to the formation of glacial ice (Benn and Evans, 2010). The glaciers which form are initially minimally erosive, because of their limited size and low ice discharge. The key element in allowing glaciers to erode and generate well developed cirques is rotational flow (Lewis, 1949, 1960), which maximises subglacial sliding (as basal friction is overcome) and removes eroded material from the glacier bed (Lewis, 1960). Rotational flow is typically thought to initiate once a glacier's surface gradient $(\alpha)$ exceeds $\sim 7^{\circ}$ (Lewis, 1960) (Fig. 5a). The mechanisms which allow such glaciers to enlarge cirques are quarrying (plucking) and abrasion (Evans, 2006a), and are maximised beneath dynamic (i.e., with high mass-flux), warmbased glaciers (Galibert, 1962; White, 1970). These mechanisms largely act to erode cirque floors (where ice velocity and discharge are greatest) and the base of cirque headwalls (Sanders et al., 2013)-with material that is plucked from headwalls and entrained into the ice thought to act as an agent of abrasion at the cirque floor (Johnson, 1904). Subglacial meltwater drainage is also thought to be an important factor in promoting erosion beneath glaciers (Benn and Evans, 2010), with the randkluft (the gap between a glacier and the cirque headwall) and bergschrund (a relatively large crevasse near, but not touching, the cirque headwall-often considered to separate immobile and mobile ice) acting as important drainage pathways from the glacier surface to the bed (Fig. 5a). During the ablation season, subglacial meltwater is likely to enhance abrasion (because of its lubricating effect) but also promote quarrying (because of diurnal variations in temperature and water pressure) (Hooke, 1991; Iverson, 1991), particularly where meltwater freezes on to, and plucks material away from, the base of the headwall (Lewis, 1938; Andrews and LeMasurier, 1973).

In addition to the abrasion and quarrying described above, periglacial processes (predominantly freeze-thaw) are important erosional agents at cirque lateral margins and at the base of the cirque headwall (which becomes progressively more exposed during the ablation seasons due to the widening of the randkluft) (Gardner, 1987; Sanders et al., 2012). Such processes play a key role in the subaerial retreat of cirque head and lateral margins (Embleton and King, 1975; Sanders et al., 2012), and removed material accumulates at the base of slopes, either on the surface of the glacier or at the glacier bed. Since glaciers act as conveyors, this debris is eventually removed, exposing bedrock to further erosion (MacGregor et al., 2009; Scherler et al., 2011; Scherler, 2014).

As cirques develop (in response to the mechanisms outlined above), they are typically thought to become enlarged (Fig. 6), leading to the assumption that cirque size can be used as a surrogate for cirque age (Sugden, 1969; Olyphant, 1981; Haynes, 1998). Most models consider cirque widening and lengthening to outpace deepening (Gordon, 1977; Brook et al., 2006), though some consider cirques to lengthen, widen and deepen at roughly similar rates (this is discussed in section 6.2.3.). During growth, cirque concavity, as reflected by 'plan' and 'profile' closure (see section 6.1.8.), is also thought to increase (Fig. 6) (Gordon, 1977; Brook et al., 2006), as cirques make the transition through the different grades of development from 'marginal' through to 'classic' forms (Evans and Cox, 1995). Whilst some have argued that cirques tend towards equilibrium 
(time-independent) forms (e.g. Linton, 1963; Sugden, 1969) (Fig. $6 a \&$ b), others (e.g., Brook et al., 2006) have suggested that cirque shape continues to evolve as they develop into elongated valley-head landforms (Fig. 6c \& d). With growth, neighbouring cirques (i.e., those side by side along one side of a ridge) can merge and coalesce (Evans, 2009; Mîndrescu and Evans, 2014) (e.g., Fig. 7a); individual cirques can erode through their headwalls (e.g., Fig. 7b); and back-to-back cirques can merge across intervening divides (though such instances are rareWhite, 1970; Evans, 2009).
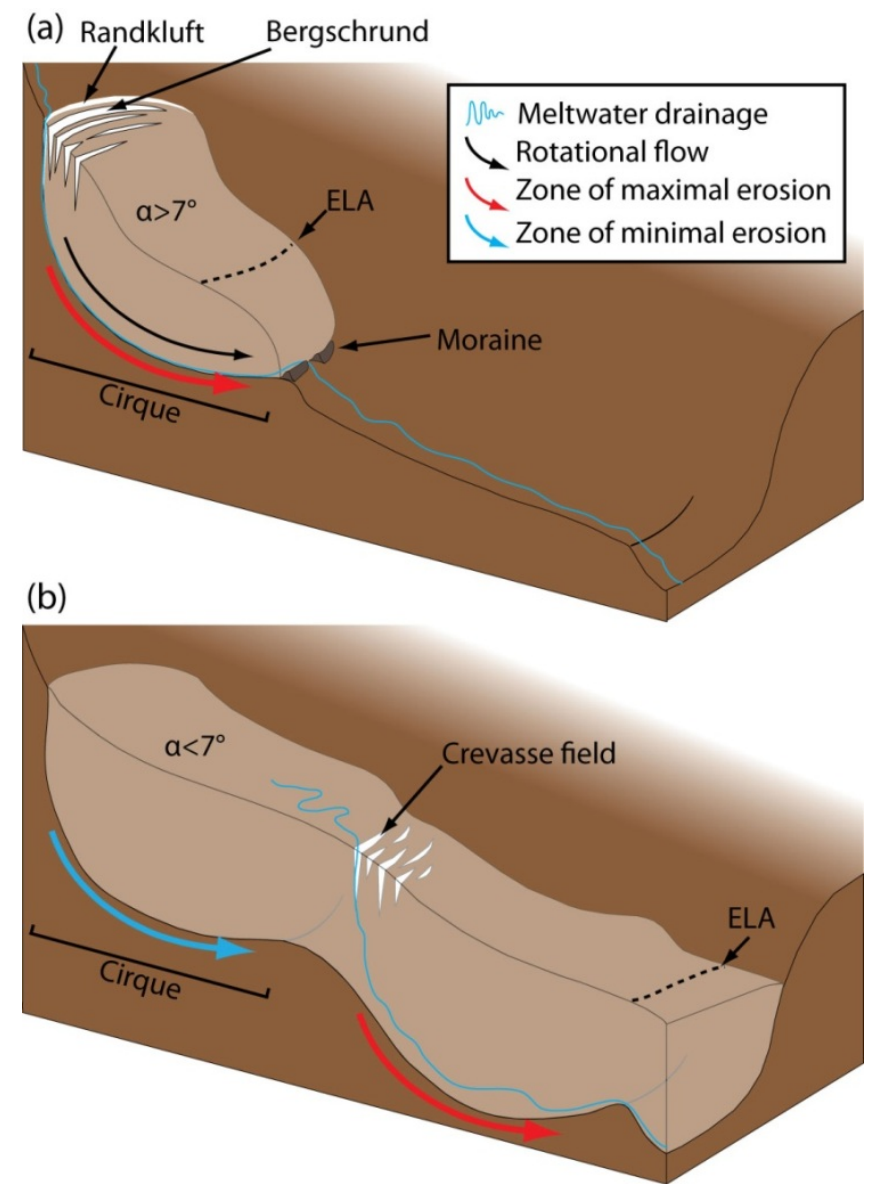

Fig. 5. Illustration of cirque development in response to different glaciation extents. (a) Active cirque development beneath a small, rotationally-flowing cirque type glacier, with subglacial meltwater drainage, and an ice surface gradient $(\alpha)>7^{\circ}$. (b) Restricted cirque development beneath a large valley glacier, where erosion is focused downvalley (beyond cirque confines) and the cirque is occupied by low gradient $\left(\alpha<7^{\circ}\right)$, potentially cold-based, minimally erosive ice. Figure (b) is based on Cook and Swift (2012).

(a)
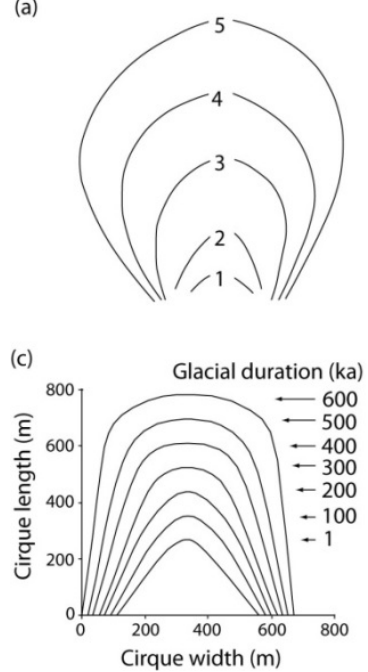

(b)
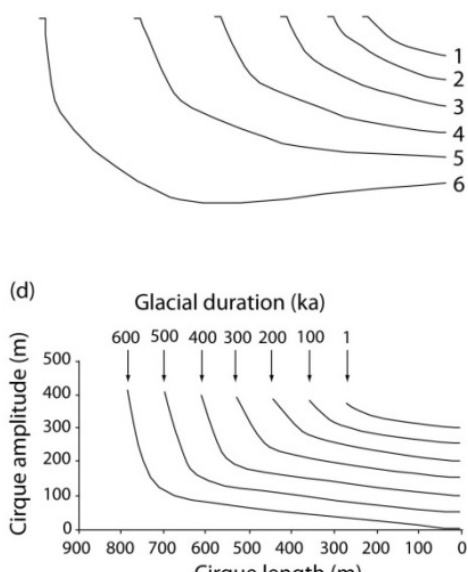

Fig. 6. Generalised depictions of cirque evolution in (a) plan-form, and (b) long-profile. Numbers correspond to different stages of cirque development. Numbers are not directly comparable to the Evans and Cox (1995) cirque classification scheme, but roughly relate to a transition from 'marginal' (1) to 'classic' (6) cirques. Plan and profile closure increase with the degree of development. (c) Plan-form, and (d) long-profile evolution of an idealised cirque in the Ben Ohau Range, New Zealand. The Ben Ohau Range model 
shows a cirque developing into an elongated valley-head landform, rather than a typical concave cirque. Figures (a) and (b) are modified from Gordon (1977). Figures (c) and (d) are modified from Brook et al (2006).


Fig. 7. Oblique Google Earth ${ }^{\mathrm{TM}}$ images showing examples from the Faroe Islands of (a) neighbouring cirques (1 and 2) beginning to coalesce $\left(62.262^{\circ} \mathrm{N}, 6.800^{\circ} \mathrm{W}\right)$, and (b) cirques (e.g., 1 and 2) beginning to erode through their headwalls $\left(62.338^{\circ} \mathrm{N}, 6.794^{\circ} \mathrm{W}\right)$.

Under the model of cirque development outlined above, cirque enlargement is thought to primarily occur during periods of restricted glaciation, when glaciers are largely constrained to their cirques. Under such conditions, the zone of maximum subglacial erosion, which is generally thought to roughly coincide with a glacier's equilibrium-line altitude (ELA) (Boulton, 1996; Hallet et al., 1996; Anderson et al., 2006), is located within the cirque (Fig. 5a) (allowing cirques to lengthen and deepen); and cirque margins are exposed to subaerial periglacial processes (allowing cirques to further lengthen and widen). However, during periods of more extensive glaciation, as the ELA shifts to an elevation below the cirque, subglacial erosion will be focused down-valley (beyond cirque confines), and cirques themselves may be occupied by cold-based ice, frozen to its substrate (Hassinen, 1998; Seif and Ebrahimi, 2014) (Fig. 5b). This is particularly true of cirques buried under ice caps or sheets (Evans, 2006a), but is also relevant when cirques are acting as the source areas for glaciers extending into valleys below, when the surface gradient of the ice within the cirques may be insufficient to allow rotational flow (i.e., $>7^{\circ}$ ) (Evans, 1999) (Fig. 5b). In addition, when cirques are submerged beneath extensive glaciers, periglacial processes are likely to be less efficient, as little, or none, of the land surface is subaerially exposed. Thus, the growth of cirques is largely limited to periods when they are occupied by small (cirque type) glaciers. This could occur multiple times during a glacial cycle, and at the very least at the onset and the end of a glaciation. Cirques are therefore likely to be actively eroded during multiple periods within a glacial cycle, and possibly over multiple glaciations.

\subsubsection{Cirque erosion rates}

The rate at which cirques grow is determined by their erosion rates. To date, published erosion rates for cirques are limited, partly because of difficulties with obtaining estimates from modern glaciers (Sanders et al., 2013), but also because of difficulties with establishing a chronology for cirque formation (i.e., estimating how long it has taken for a cirque to be eroded). The data currently available (summarised in Table 1) suggest erosion rates in the $0.008-5.9 \mathrm{~mm} \mathrm{a}^{-1}$ range. One notable characteristic is that rates show regional variation, likely driven by variations in climate, glacier dynamics, bedrock lithology, structure, and pre-glacial topography. In addition, the data Table 1. Published cirque erosion rates (Table based on Sanders et al., 2013) appear to indicate that headward erosion rates exceed both lateral and vertical erosion rates. For example, in Marie Byrd Land Antarctica, Andrews and LeMasurier (1973) found headwall erosion rates $\left(\sim 5.8 \mathrm{~mm} \mathrm{a}^{-1}\right)$ to far exceed those of sidewalls ( $\left.0.8 \mathrm{~mm} \mathrm{a}^{-1}\right)$, which were in turn found to exceed rates of vertical incision ( $\left.0.4 \mathrm{~mm} \mathrm{a}^{-1}\right)$. Similarly, in the eastern Kyrgyz Range of central Asia, Oskin and Burbank (2005) note that the rate of headwall retreat is two to three times the rate of vertical incision (because subglacial erosion is often localised at the base of cirque headwalls-promoting headward erosion). By contrast, in the Canadian Rockies, British Columbia, Sanders et al. (2013) found rates of headward retreat and vertical incision over the past halfcentury to have been roughly equivalent (i.e., 1.2 and $0.5-0.9$ $\mathrm{mm} \mathrm{a}{ }^{-1}$, respectively), though they acknowledge that, given the uncertainties in their estimates, headwall retreat may have significantly outpaced cirque deepening.

Given the erosion rates in Table 1, a general consensus is that cirque development takes hundreds of thousands of years (Jansson et al., 1999; Gordon, 2001; Evans, 2006a), with hollows approaching the morphology of glacial cirques after c.400 ka, attaining well-developed cirque shapes after $600 \mathrm{ka}$, and perhaps being fully developed after $\sim 750$ ka of glacial occupancy (Brook et al., 2006) (Fig. 6c \& d). However, given spatial variability in erosion rates (Table 1), estimates of the time necessary for cirque development range from $125 \mathrm{ka}$ (Larsen and Mangerud, 1981) to a million years or more (Andrews and Dugdale, 1971; Anderson, 1978; Sanders et al., 2013). Turnbull and Davies (2006) argued that there has been insufficient time during the Quaternary to allow glaciers to have eroded medium to large cirques from small initial hollows (they assume an erosion rate of $\sim 1 \mathrm{~mm} \mathrm{a} \mathrm{a}^{-1}$ ), particularly since cirque erosion rates are likely to have diminished during periods of extensive glaciation (see section 2.2.). As an alternative, they suggested a mass movement origin for such cirques, arguing that they reflect regions where glaciers have come to occupy large and preexisting cirque-like hollows formed by deep seated rock slope failures (Turnbull and Davies, 2006). Though some cirques undoubtedly initiate from such hollows (i.e., glaciers come to occupy mass movement scars), how ubiquitous this is remains uncertain. 


\begin{tabular}{|c|c|c|c|c|}
\hline Location & $\begin{array}{l}\text { Vertical erosion rate }(\mathrm{mm} \\
\left.\mathrm{a}^{-1}\right)\end{array}$ & $\begin{array}{l}\text { Headward/sidewall erosion rate ( } \mathrm{mm} \\
\left.\mathrm{a}^{-1}\right)\end{array}$ & $\begin{array}{l}\text { Timescale } \\
\text { (years) }\end{array}$ & Citation \\
\hline Marie Byrd Land, Antarctica & 0.4 & $5.8 / 0.8$ & $3-8 \times 10^{5}$ & $\begin{array}{l}\text { Andrews and LeMasurier } \\
\text { (1973) }\end{array}$ \\
\hline $\begin{array}{l}\text { Arapaho Glacier, Front Range, } \\
\text { Colorado, USA }\end{array}$ & $0.095-0.17$ & - & Recent & Reheis (1975) \\
\hline Pangnirtung Fiord, Baffin Island, Canada & $0.008-0.076$ & - & $\sim 10^{3}$ & Anderson (1978) \\
\hline Sangre de Cristo Range, Colorado, USA & - & $0.92-1.31$ & $\sim 10^{4}$ & Grout (1979) \\
\hline Kråkenes, Norway & $0.5-0.6$ & 0.1 & $7 \times 10^{5}$ & Larsen and Mangerud (1981) \\
\hline Rocky Mountains & $0.147-1.811$ & - & $10^{3}-10^{4}$ & Olyphant (1981) \\
\hline Ivory Lake, Southern Alps, New Zealand & $5.3-5.9$ & - & 4 & Hicks et al. (1990) \\
\hline Ovre Beiarbreen, Norway & 0.18 & - & 6 & Bogen (1996) \\
\hline Ben Ohau Range, New Zealand & 0.29 & 0.44 & $7.5 \times 10^{5}$ & Brook et al. (2006) \\
\hline Nisqually Glacier, Washington, USA & 5.0 & - & Recent & Mills (1979) \\
\hline $\begin{array}{l}\text { Canadian Rocky Mountains, British } \\
\text { Columbia }\end{array}$ & $0.5-0.9$ & 1.2 & 50 & Sanders et al. (2013) \\
\hline
\end{tabular}

\subsection{Cirques as indicators of past environments}

Though factors such as bedrock lithology, structure and pre-glacial topography play an important role (as discussed in section 7.), a key factor in regulating cirque initiation and development is the dynamics, frequency and duration of glaciations, which are, in turn, regulated by climate. When occupied by glaciers, cirques are often defined as 'active', and are 'inactive' when glacier-free (e.g., Bathrellos et al., 2014); though a better classification might also include reference to 'dormant' cirques (i.e., when occupied by extensive, but minimally erosive, glaciers; as in Fig. 5b). Active (and dormant) cirques are of limited use as paleoenvironmental indicators, since detailed analysis of their properties (e.g., their floor altitudes) is not possible (Mitchell and Humphries, 2015). By contrast, the attributes of inactive cirques are readily measured, and can provide information about past environments. Specifically, cirques can provide information about the style, duration and intensity of the glacial and periglacial conditions that formed them (Delmas et al., 2015). Cirques can also provide information about temperatures, precipitation gradients, cloud-cover and wind directions during former periods of glaciation (e.g., Hughes et al., 2007; Anders et al., 2010; Mîndrescu et al., 2010). Obtaining such information typically involves analysing one, or more, of the following factors: (i) cirque distribution; (ii) cirque aspect; (iii) cirque floor altitudes; and (iv) cirque morphometry (i.e., size and shape). These factors are discussed in detail here (in sections 3, 4, 5, and 6, respectively), with specific focus on how attributes are measured, some of the common trends observed, and consideration of how this information can be used to infer palaeoenvironmental conditions.

\section{Cirque distribution}

\subsection{Cirque identification and mapping}

The first stage in analysing the distribution of cirques is their identification and mapping. This is typically conducted in the field, from topographic maps (e.g., Evans and Cox, 1995), and, in recent years, from aerial photographs, satellite images and digital elevation models (DEMs) (e.g., Federici and Spagnolo,
2004; Seif and Ebrahimi, 2014). In many cases, cirque identification often begins with recognition of a comparatively flat (sometimes slightly outward sloping), or overdeepened, basin (sometimes filled by a lake) in an upland setting, with evidence that this area is enclosed by an arcuate headwall upvalley but is open downvalley (e.g., Fig. 1). Flat surfaces of this type are typically absent from fluvial valley heads, though large slope failures can leave semicircular valley-head landslide scars (Hovius and Stark, 2006). Once a cirque has been identified (e.g., Fig. 1a), slope maps are often produced (e.g., Mîndrescu and Evans, 2014; Seif and Ebrahimi, 2014) (e.g., Fig. 8a). Such maps allow the upper limits of cirques (i.e., cirque headwall crests) to be identified as sharp convex breaks of slope, forming a transition from headwalls to shallower areas above (Evans and Cox, 1995; Mîndrescu and Evans, 2014) (Fig. 8a \& c). Such transitions can coincide with the abrupt termination of pre-glacial channels incised into cirque headwalls and sidewalls. Where clear geomorphological evince of the former upper limit of a glacier is lacking, the upper limits of cirque headwalls are sometimes drawn to coincide with a gradient of $\sim 27^{\circ}$ (Fig. 8a \& b), since, according to Evans and Cox, (1995), the floor typically slopes < $20^{\circ}$, and the headwall slopes $>35^{\circ}$. Down-valley cirque limits are often marked by a convex cirque 'threshold' (or 'lip' or 'sill'), followed by a steep drop to the valley floor below (Evans and Cox, 1995) (e.g., Fig. 2). This threshold can be readily identified from topographic- or DEM-derived slope maps, but is also apparent in the field and in aerial/satellite images as an area of smooth, sometimes striated, bedrock and/or as a frontal moraine (deposited during the last stage of cirque occupation). Where a threshold is lacking, downvalley margins are drawn to coincide with the extent of a cirque's lateral spurs (e.g., Evans and Cox, 1995) or cirque headwall crests are mapped (as arcuate lines) without delimiting lower margins (e.g., Fig. 1a). However, most cirques are now mapped as fully enclosed polygons, which allow a complete set of relevant metrics to be analysed (e.g., Federici and Spagnolo, 2004) (e.g., Fig. 8b). 

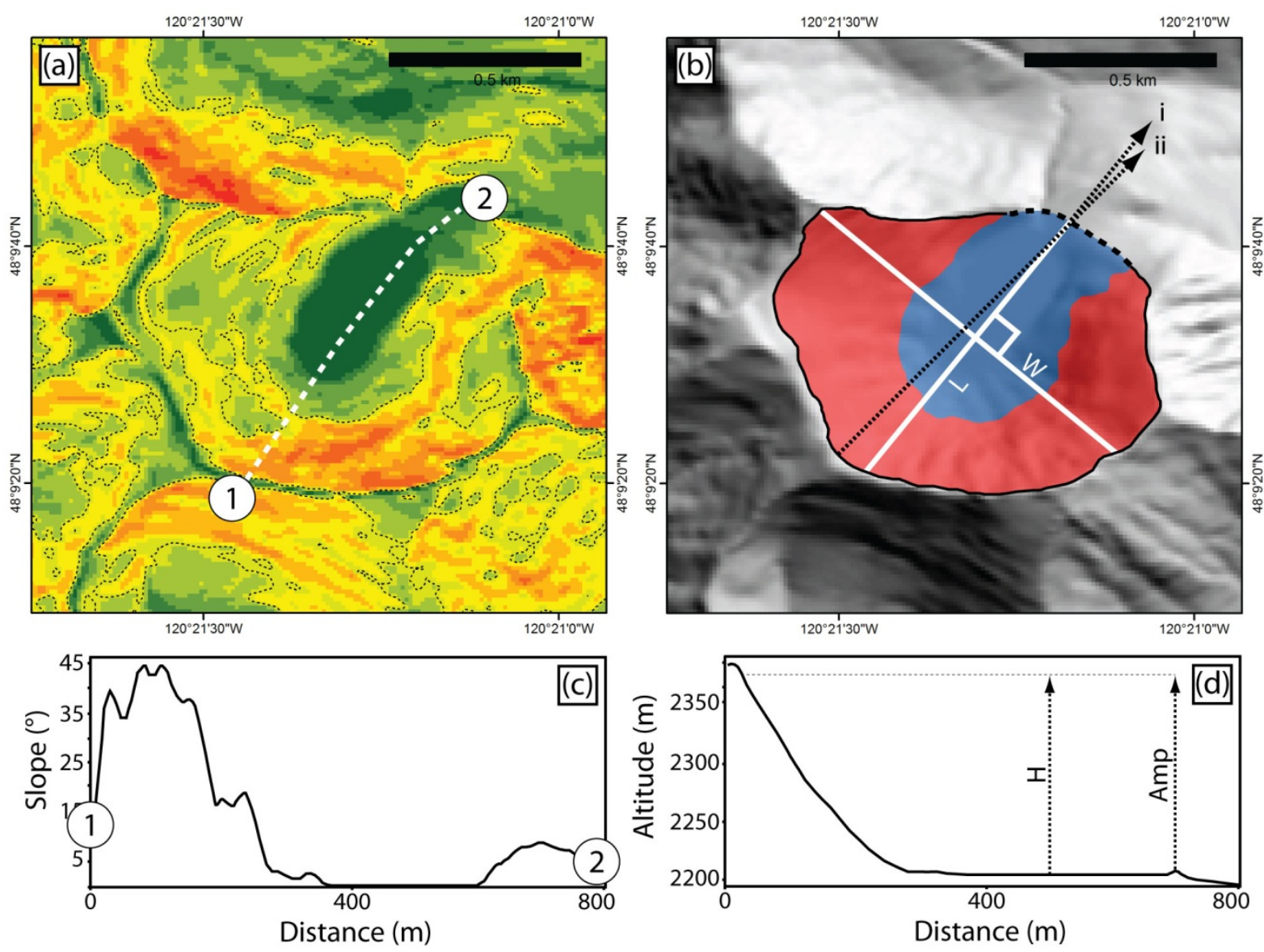

Fig. 8. Maps of Sunrise Lake Cirque $\left(48.160^{\circ} \mathrm{N}, 120.354^{\circ} \mathrm{W}\right)$, Washington, USA (as in Fig. 1). (a) Slope map. The dashed black lines correspond to a land surface gradient of $27^{\circ}$, and are sometimes used to define the upper and lower limits of the cirque headwall (i.e., the headwall is assumed to have a gradient $>27^{\circ}$ ). (b) Mapped cirque, showing the headwall (red), floor (blue), threshold (bold dashed line), length (L) and width (W). Dashed arrows ' $i$ ' and 'ii' are the median and longest axis aspect, respectively. (c) Cross section of slope and (d) topography, extending from points 1 to 2 . In (d), ' $\mathrm{H}$ ' is cirque height range, and 'Amp' is cirque amplitude. Each of these definitions is discussed in the text.

\subsection{Common trends in cirque distribution}

Cirques have been mapped in mountain ranges all over the world, including under the Antarctic ice sheet (Holmlund and Näslund, 1994; Rose et al., 2013), and cirque-like forms are even evident on Mars (Kargel and Strom, 1992; Hubbard et al., 2014) (e.g., Fig. 9). Cirques typically occupy upland peaks, but are also found cut into plateau surfaces (e.g., western Kamchatka-Barr and Spagnolo, 2013), and can be found at modern sea level (e.g., on the Faroe Islands-Fig. 7). In fact, because of the control precipitation exerts on glacier development and dynamics, cirques are often found to concentrate in coastal areas (Principato and Lee, 2014). Though it has been long-known that cirques are ubiquitous in formerly glaciated regions globally, it wasn't until the adoption of remote sensing and GIS techniques that large populations could be mapped and analysed at local, regional, and continental scales (see summaries in Evans 1977; Barr and Spagnolo, 2013; Delmas et al., 2015; Mitchell and Humphries; 2015).

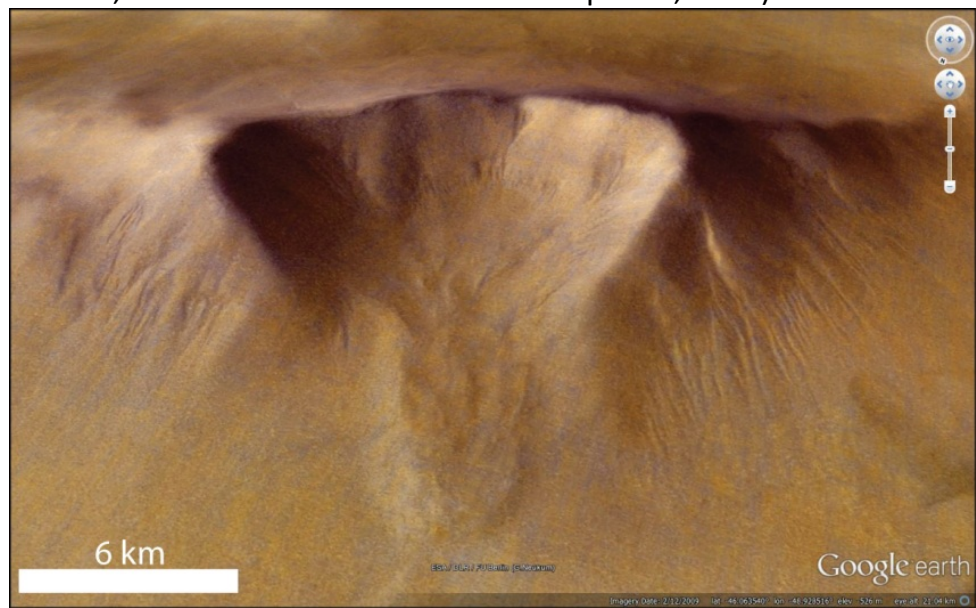

Fig. 9. Oblique Google Earth ${ }^{\mathrm{TM}}$ image of a cirque-like form on Mars (location: $46.164^{\circ} \mathrm{S}, 48.884^{\circ} \mathrm{W}$ ).

\subsection{Cirque distribution as a palaeoenvironmental indicator}


Since inactive cirques mark the locations of former glacier source areas, their presence is an excellent indicator that a region was glaciated (Evans, 2006a). While in many regions, such as Snowdonia (NW Wales), cirques were already being used in this way during the mid-19 ${ }^{\text {th }}$ century (e.g., Darwin 1842), in other locations this has happened much more recently. For example, Chen et al. (2014) used the presence of cirques to infer former glaciation in the Daweishan Mountains (eastern China), where dispute about whether the region was formerly glaciated has continued for over 80 years. Cirques are not only used, in this way, to indicate the former presence of glaciers, but also suggest that a specific set of topoclimatic conditions have been in place for those glaciers to exist. Specifically, based on our understanding of the requirements for cirque formation (outlined in section 2.2.), the presence of cirques in a given location tells us that at some point in the past, perennial snow was able to survive summer melt and build to a thickness that enabled metamorphosis and the formation of glacial ice. The glaciers that resulted were steep enough to undergo rotational flow (i.e., $\alpha>7^{\circ}$ ) (Lewis, 1949, 1960), and were dynamic (i.e., with high ice-flux) and/or sufficiently long-lasting (perhaps present during repeated phases of glaciation) to directly and/or indirectly excavate their underlying bedrock. Assuming favourable topographic and geological conditions, climate then becomes the most important factor in controlling the presence or absence of a cirque in a particular locality. Under a maritime climate, with high winter precipitation and relatively warm summers, cirques are likely able to develop comparatively rapidly, possibly in the order of hundreds of thousands of years (Gordon, 2001; Brook et al., 2006; Evans, 2006a). By contrast, under cryoarid conditions (i.e., in continental climates), cirques might take a million years or more to fully develop (Andrews and Dugdale, 1971; Anderson, 1978; Sanders et al., 2013). In this way, the presence of cirques in a given location provides qualitative information about regional palaeoclimate. For example, the concentration of cirques in some coastal areas (e.g., along the western side of Vestfirðir, NW Iceland; Principato and Lee, 2014) likely reflects their ability to rapidly develop under favourable (i.e., maritime) climatic conditions, whilst within the same time frame, cirques have been unable to fully develop further inland because of an unfavourable palaeoprecipitation gradient (i.e., snowfall inland was too low to allow glacier development in general, and/or insufficient for the development of dynamic, and therefore erosive, glaciers).

Not only is the presence of cirques indicative of past environmental conditions, but their absence is also potentially informative. In a simple sense, the absence of cirques might indicate that conditions in a particular region were not conducive to the development of glaciers (perhaps during the Quaternary). However, the absence of cirques isn't necessarily a clear indicator of the absence of former glaciers. For example, former glaciers may have quickly developed into valley glaciers or larger ice masses, thus keeping the heads of valleys mostly occupied by cold-based, and therefore minimally erosive, ice. Similarly, former glaciers may have flowed over notably resistant bedrock, meaning that they were unable to generate clear cirques during the time of a glaciation. In addition, the post-glacial modification of cirques means that some (particularly those which were poorly developed in the first place) may be difficult to identify in the modern landscape (see section 7.2.)-thus, the apparent absence of cirques doesn't necessarily mean the former absence of cirque-forming glaciers. Despite such limitations, the absence of cirques in a location where they might be 'expected' (e.g., in proximity to other cirque-occupied mountains of similar altitude, lithology and climate) might provide information about past environmental conditions. For example the absence of cirques in such a locality might reflect palaeoclimatic gradients which are no longer present (e.g., during former periods of glaciation palaeoprecipitation patterns may have differed significantly from present).

\section{Cirque aspect}

\subsection{Definition and measurement}

Aspect (often recorded as azimuth) is a measure of a feature's geometric orientation in the horizontal plane (measured in degrees clockwise from north) and is a circular variable (i.e., its extremes of 0 and $360^{\circ}$ are identical). Cirque aspect can be defined in a number of ways. One commonly used approach is to measure the median axis aspect (Evans, 1977; Evans and Cox, 1995), which is the aspect of a line passing through the middle of the cirque threshold, and intersecting the cirque headwall in a way that splits the cirque into two exactly equal halves (Fig. 8b). The median axis aspect is often preferred to measurement of a cirque's longest axis (i.e., the aspect of a line connecting the middle of the cirque threshold to the furthest point on the headwall crest) (Evans, 1977) (Fig. 8b), as this might bear little relation to the direction the cirque is facing (particularly in the case of wide cirques). Other measures of cirque aspect include the aspect orthogonal to the steepest segment of the headwall (Delmas et al., 2015), and the aspect orthogonal to the point where headwall height is greatest (Mîndrescu and Evans, 2014). An alternative approach is to measure the gradient-weighted mean headwall aspect (where a greater weight is given to the steeper parts of the headwall). Evans and Cox (1995) suggested that this is probably more representative of the aspect of former glacier source areas, and its use has been recommended for future studies (Mîndrescu and Evans, 2014). However, the method is rarely used, despite the fact that GIS techniques (and particularly the use of DEMs) have simplified its implementation considerably (cf., Evans and Cox, 1995).

Once measured, cirque aspects have been plotted using cumulative vector diagrams (Evans, 1977; Hassinen, 1998; Nelson and Jackson, 2003) (e.g., Fig. 10a), but it is more common to plot aspects in rose diagrams (Evans, 1977; DeGraff, 1979; Bathrellos et al., 2014) (e.g., Fig. 10b \& c). Both approaches allow the "vector mean" and "vector strength" of the entire cirque population to be calculated (Table 2). Vector mean represents the mean aspect of an entire cirque population (and is the only valid mean for directional data; Evans, 1977), while vector strength is a measure of the degree of asymmetry in cirque aspects (i.e., a measure of the variability in cirque aspects within a population). Evans (1977) suggested the following interpretation of vector strength: $>80 \%=$ extremely asymmetric; $60-80 \%$ = strongly asymmetric; $40-60 \%$ = markedly asymmetric; $20-40 \%=$ weakly asymmetric; $<20 \%=$ symmetric. Many studies simply classify cirque aspect according to a limited number of compass points (N, NE, E, etc.) (e.g., Krrížek et al., 2012; Bathrellos et al., 2014), however, vector mean and vector strength remain useful statistics in allowing comparison between cirque populations (Evans, 1969; 1977; Unwin, 1973) (Table 2). 


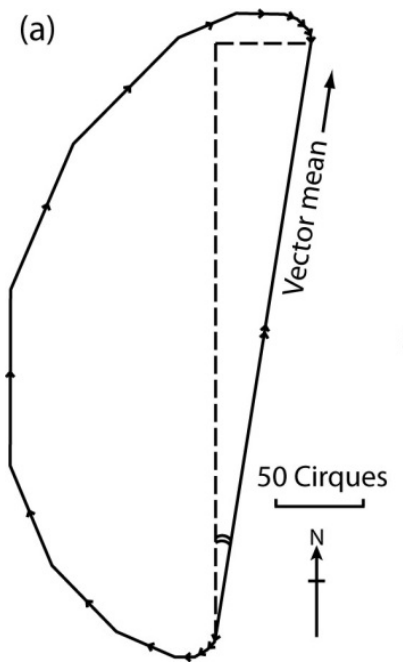

(b)

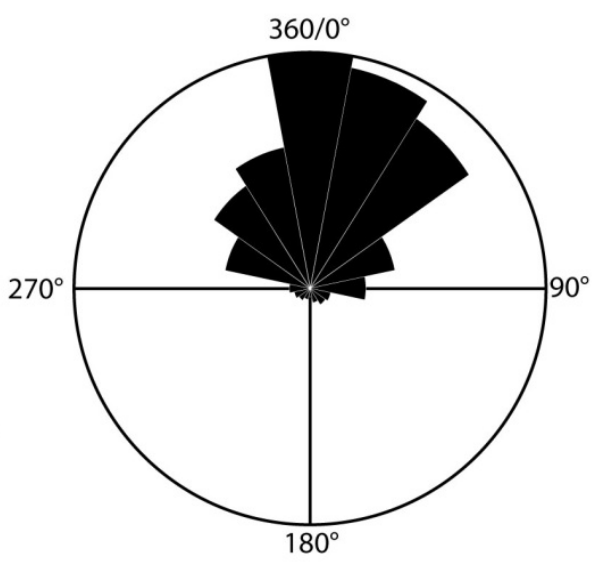

(c)

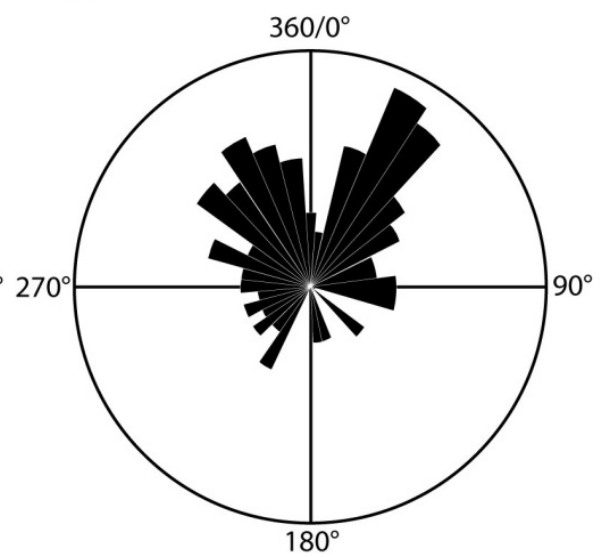

Fig. 10. (a) Cumulative vector diagram, and (b) rose diagram showing the aspect distribution of 532 cirques in the Bridge River area, British Columbia. In this instance, the vector mean is $009^{\circ}$, and the vector strength is $63 \%$. Figure modified from Evans (1977). (c) Rose diagram showing the multimodal aspect distribution of 100 cirques on Vestfirðir, NW Iceland. Figure modified from Principato and Lee (2014).

Table. 2. A global population of studies where cirque aspect vector mean and vector strength are reported (pre 1981 data are from Evans, 1977). In some cases (particularly in Wales and the English Lake District) several datasets cover the same, or overlapping, areas.

\begin{tabular}{|c|c|c|c|c|c|}
\hline Region & $\begin{array}{l}\text { Number of cirques } \\
\text { mapped }\end{array}$ & $\begin{array}{l}\text { Aspect vector } \\
\text { mean }\left({ }^{\circ}\right)\end{array}$ & $\begin{array}{l}\text { Aspect vector } \\
\text { strength }(\%)\end{array}$ & $\begin{array}{l}\text { Latitude } \\
\left({ }^{\circ} \mathrm{N}\right)\end{array}$ & Citation \\
\hline Kamchatka, Russia & 3520 & 006 & 46 & 56.5 & Barr and Spagnolo (2013) \\
\hline Romania & 631 & 063 & 31 & 46.0 & $\begin{array}{l}\text { Mîndrescu et al (2010); Mîndrescu } \\
\text { and Evans (2014) }\end{array}$ \\
\hline Wales & 260 & 049 & 58 & 52.8 & Evans (2006a) \\
\hline $\begin{array}{l}\text { Retezat Mountains, Transylvanian } \\
\text { Alps, Romania }\end{array}$ & 31 & 035 & 23 & 45.3 & Urdea (2001) \\
\hline Wales & 228 & 047 & 55 & 52.8 & Evans (1999) \\
\hline Northern Scandinavia & 539 & 040 & 30 & 69.2 & Hassinen (1998) \\
\hline English Lake District & 158 & 049 & 60 & 54.5 & Evans and Cox (1995) \\
\hline Cayoosh Range, British Columbia & 198 & 011 & 56 & 50.6 & Evans (1994) \\
\hline Kintail-Aifric-Cannich, NW Scotland & 260 & 051 & 57 & 57.2 & Gordon (1977) \\
\hline Bendor Range, British Columbia & 186 & 012 & 56 & 50.7 & Derbyshire and Evans (1976) \\
\hline Rocky Mountains, USA & 240 & 068 & 30 & 46.4 & Graf (1976) \\
\hline Cumbria, England & 198 & 051 & 55 & 54.5 & Clough $(1974,1977)$ \\
\hline Tatlow Range, British Columbia & 71 & 009 & 60 & 51.4 & Evans (1974) \\
\hline Bridge River area, British Columbia & 538 & 009 & 64 & 50.7 & \\
\hline $\begin{array}{l}\text { Northern Garibald, British } \\
\text { Columbia }\end{array}$ & 193 & 006 & 59 & 49.9 & \\
\hline Custer Range, British Columbia & 38 & 001 & 62 & 49.2 & \\
\hline Central Japan & 22 & 070 & 77 & 35.9 & \\
\hline South Lapland & 112 & 116 & 47 & 68.6 & Soyez (1974) \\
\hline $\begin{array}{l}\text { Eastern Banff National Park, } \\
\text { Alberta }\end{array}$ & 53 & 027 & 29 & 51.1 & McLaren and Hills (1973) \\
\hline $\begin{array}{l}\text { Andöya \& Langöya, Northern } \\
\text { Norway }\end{array}$ & 89 & 042 & 63 & 68.6 & Moller and Sollid (1973) (\& P. C.) \\
\hline Grytöya, Northern Norway & 33 & 141 & 65 & 68.9 & \\
\hline Spain & 11 & 037 & 66 & 43 & Schmidt-Thomé (1973) \\
\hline $\begin{array}{l}\text { Orense/Minho border area, } \\
\text { Portugal and Spain }\end{array}$ & 36 & 349 & 32 & 41.8 & \\
\hline Snowdonia, NW Wales & 81 & 048 & 57 & 53.1 & Unwin (1973) \\
\hline Falkland Islands & 24 & 090 & 79 & -51.7 & Clark (1972) \\
\hline Papua-New Guinea & 182 & 183 & 24 & -5.7 & Löffler (1972) \\
\hline Rio Aconcagua area, Chile & 112 & 168 & 37 & -32.9 & Wojciechowski and Wilgat (1972) \\
\hline $\begin{array}{l}\text { Khr. Svidoyvets, Ukranian } \\
\text { Carpathians }\end{array}$ & 16 & 052 & 77 & 48.3 & Bashenina (1971) \\
\hline Falkland Islands & & 077 & 68 & -51.7 & Clapperton (1971) \\
\hline Fagaras, Southern Romania & 133 & 064 & 18 & 45.6 & Gâștescu (1971) \\
\hline Paring, Southern Romania & 40 & 053 & 45 & 45.3 & \\
\hline Retezat, Southern Romania & 48 & 020 & 33 & 45.3 & \\
\hline Okoa Bay, Arctic Canada & 159 & 021 & 46 & 67.9 & Andrews et al. (1970) \\
\hline Home Bay, Arctic Canada & 79 & 036 & 51 & 69.6 & \\
\hline $\begin{array}{l}\text { Presidential Range \& Mt. Katahdin, } \\
\text { New England }\end{array}$ & 20 & 076 & 41 & 44 & Goldthwait (1970) \\
\hline Brecon Beacons, Wales & 13 & 044 & 67 & 51.8 & Lewis (1970) \\
\hline
\end{tabular}




\begin{tabular}{|c|c|c|c|c|c|}
\hline Scotland & 876 & 044 & 24 & 56.6 & Sale (1970) \\
\hline Cumbria, England & 104 & 062 & 28 & 54.5 & \\
\hline North Wales & 118 & 059 & 33 & 53.1 & \\
\hline South Wales & 15 & 030 & 65 & 51.8 & \\
\hline Galicia and W. León, Spain & 151 & 049 & 53 & 42.5 & Schmitz (1969) \\
\hline Cairngorms, Scotland & 30 & 047 & 57 & 57.1 & Sugden (1969) \\
\hline Böhmerwald, Germany & 19 & 064 & 60 & 49.1 & Ergenzinger (1967) \\
\hline Yukon-Tanana upland, Alaska & 1087 & 001 & 25 & 65.1 & Péwé et al (1967) \\
\hline Yukon-Tanana upland, Alaska & 387 & 017 & 68 & 65.1 & \\
\hline Cumbria, England & 28 & 047 & 65 & 54.5 & Pippan (1967) \\
\hline Scotland & 347 & 047 & 54 & 56.6 & Sissons (1967) \\
\hline $\begin{array}{l}\text { Vosges \& Schwarzwald, Central } \\
\text { Europe }\end{array}$ & 179 & 064 & 68 & 48.1 & Zienert (1967) \\
\hline $\begin{array}{l}\text { Northern Nain-Okak, Labrador, } \\
\text { Canada }\end{array}$ & 29 & 029 & 68 & 56.1 & Andrews (1965) \\
\hline NW Scotland & 437 & 048 & 51 & 57.6 & Godard (1965) \\
\hline $\begin{array}{l}\text { En.Terek Khr., Altai, Southern } \\
\text { Siberia }\end{array}$ & 97 & 028 & 80 & 49.8 & Ivanovskiy (1965) \\
\hline Katun Khr., Altai, Southern Siberia & 390 & 027 & 33 & 49.9 & \\
\hline $\begin{array}{l}\text { Aygulak Khr., Altai, Southern } \\
\text { Siberia }\end{array}$ & 43 & 039 & 88 & 49.7 & \\
\hline Godeanu, Southern Romania & 69 & 106 & 24 & 45.3 & Niculescu (1965) \\
\hline West-Central Cumbria, England & 73 & 040 & 47 & 54.5 & Temple (1965) \\
\hline $\begin{array}{l}\text { Lorea and Mieminger groups, } \\
\text { Austria }\end{array}$ & 20 & 028 & 80 & 47.2 & Abele (1964) \\
\hline Suntar-Khayata, Eastern Siberia & 233 & 353 & 60 & 62 & Kornilov (1964) \\
\hline Faroe Islands & 154 & 068 & 58 & 62.2 & Oberbeck (1964) \\
\hline Snowy mountains, Australia & 13 & 124 & 73 & -36.4 & Galloway (1963) \\
\hline Oamaru area, New Zealand & 104 & 100 & 52 & -44.8 & Mutch (1963) \\
\hline Coer d'Alene, Idaho & 39 & 013 & 90 & 48.2 & Dort (1962) \\
\hline Brandon peninsula, SW Ireland & 34 & 027 & 64 & 52.2 & King and Gage (1961) \\
\hline Trinity Alps, California & 33 & 010 & 69 & 40.9 & Sharp 1960 (\& p.c.) \\
\hline $\begin{array}{l}\text { Sa. de Guadarrama and } \\
\text { Somosierra, Spain }\end{array}$ & 27 & 106 & 74 & 42.8 & Fränzle (1959) \\
\hline San Bernardino, California & 9 & 024 & 91 & 34.1 & Sharp et al. (1959) \\
\hline Cumbria, England & 67 & 053 & 49 & 54.5 & Spencer (1959) \\
\hline Snowdonia, NW Wales & 34 & 045 & 72 & 53.1 & Seddon (1957) \\
\hline Västerbotten, Sweden & 93 & 125 & 47 & 65.6 & Rudberg (1954) \\
\hline $\begin{array}{l}\text { Maramureș Carpathian, Northern } \\
\text { Romania }\end{array}$ & 14 & 055 & 83 & 47.5 & Sawicki (1911) \\
\hline Wasatch Mountains, Utah & 64 & 337 & 25 & 40.5 & Atwood (1909) \\
\hline Cuillin, Scotland & 52 & 018 & 32 & 57.2 & Harker (1901) \\
\hline Santa Fe Mountains, New Mexico & 50 & 073 & 42 & 35.9 & $\begin{array}{l}\text { Webb and Averill (1901) in Salisbury } \\
\text { (1901) }\end{array}$ \\
\hline Jotunfjelds, Southern Norway & 37 & 012 & 66 & 61.8 & Helland (1877) \\
\hline Jostedalsbreen, Southern Norway & 41 & 016 & 61 & 61.7 & \\
\hline Torridon (north), Scotland & 30 & 031 & 60 & 57.6 & Bain (p.c.) \\
\hline Sierra Nevada, California & 85 & 035 & 31 & 36.7 & Derbyshire (p.c.) \\
\hline Tasmania, Australia & 265 & 109 & 64 & -42.6 & \\
\hline South Wales & 25 & 022 & 71 & 51.8 & Ellis-Grufydd (p.c.) \\
\hline Norway & 132 & 018 & 22 & 61.8 & Pippan (p.c.) \\
\hline Snoqualmie Pass, Washington & 189 & 033 & 33 & 48.4 & Porter (p.c.) \\
\hline Cumbria England & 102 & 047 & 49 & 54.5 & Whitaker (p.c.) \\
\hline
\end{tabular}

p.c. refers to personal communication in Evans (1977)

\subsection{Common trends in cirque aspect}

One key feature about glacial cirques is that they often show preferred orientations (see the relatively high values for vector strength in Table 2). In the Northern Hemisphere, the tendency is for cirques to face towards northerly directions, often with a modal aspect towards the NE (Evans 1977; Evans 2006b) (e.g., Fig. 10). In the Southern Hemisphere, the strong bias is towards southerly directions (e.g., Löffler, 1972; Wojciechowski and Wilgat, 1972), often with a modal aspect towards the SE (e.g., Galloway, 1963; Mutch, 1963) (Table 2). Thus, the preferred orientations for cirques are generally poleward, though there are some notable deviations from this, especially in mid-latitude areas, where cirques have a tendency to face eastward (Evans, 1977; Benn and Evans, 2010) (Table 2). Also, in some instances, cirque aspect distribution tends to be bimodal or multimodal, often with notable secondary modal aspects, for example towards the NW (e.g., Nelson, 1998; Principato and Lee, 2014) (e.g., Fig. 10c). Thus, cirques typically have preferred aspects but values and the strength of aspect asymmetry differ markedly from population to population. For example, Table 2 demonstrates vector strengths ranging from 12 to $91 \%$ for various cirque populations globally. The strength of aspect asymmetry typically decreases with cirque population altitude (Olyphant, 1977) (Fig. 11), and, in theory, with latitude (Benn and Evans, 2010), though this latter trend is far from clear when the data in Table 2 are considered. There is also evidence that aspect asymmetry is weaker in coastal environments, and stronger in continental climates (Evans, 1977; Nelson and Jackson, 2003). 

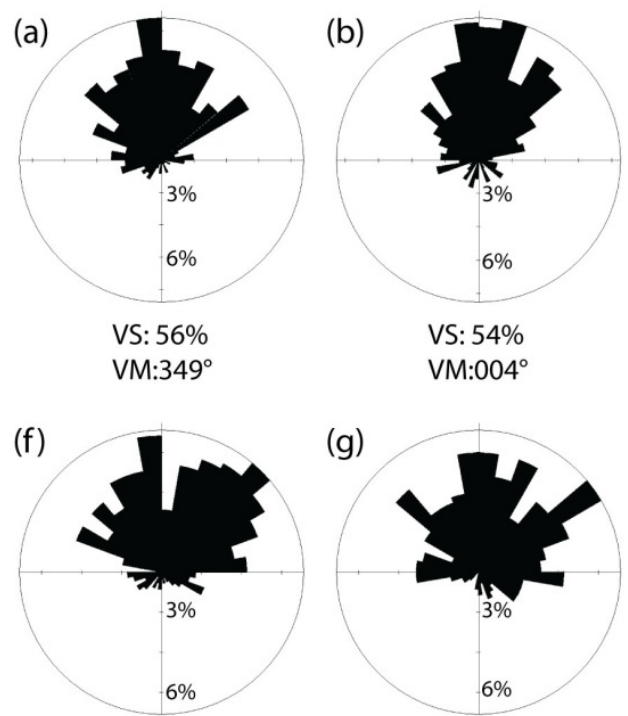

VS: $50 \%$

$\mathrm{VM}: 015^{\circ}$

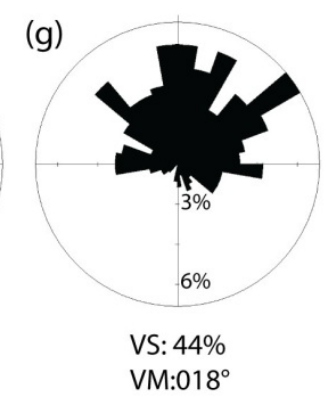

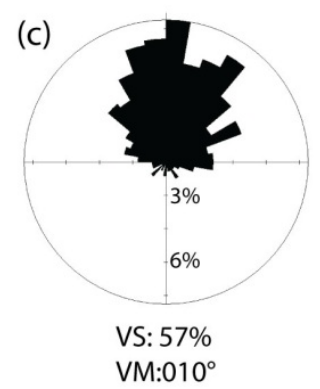
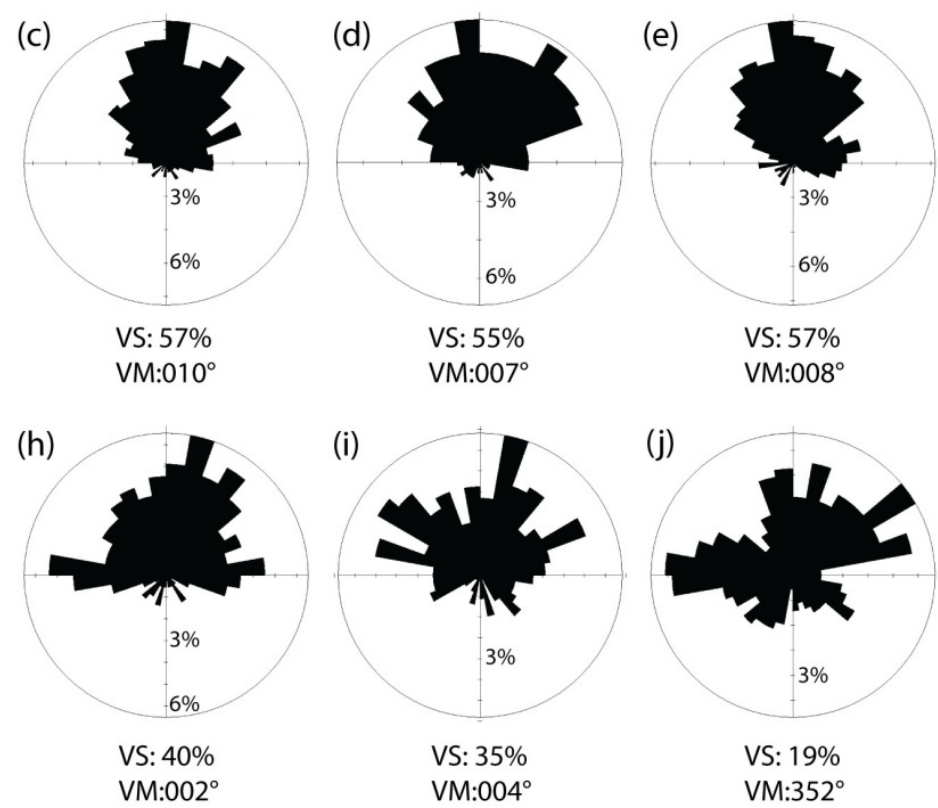

Fig. 11. Rose diagrams showing the aspect of 3520 cirques on the Kamchatka Peninsula, grouped according to their altitude (352 cirques are represented in each diagram). Groups range from (a) the lowest 352 cirques, to (j) the highest 352 cirques. The image demonstrates a reduction in vector strength (i.e., aspect asymmetry) with altitude. Figure modified from Barr and Spagnolo (2013).

\subsection{Cirque aspect as a palaeoenvironmental indicator}

A number of factors, including lithology, structure and topography, have an impact on cirque aspect (see section 7.1.2.); yet, when analysed over large and diverse (geologically and topographically) areas, the dominant controlling factor is climate (Evans, 1977; Barr and Spagnolo, 2013). This is reflected by the strong relationship between the aspects of inactive cirques, and the accumulation area aspects of nearby modern glaciers (Evans, 1977). This relationship suggests that understanding climatic controls on the accumulation area aspects of modern glaciers is a key basis for obtaining palaeoclimatic information from the aspects of cirques (Evans, 2006b). In general, and in order of importance (according to Evans, 1977), the dominant climatic factors regulating glacier accumulation area aspects (and by extension cirque aspects) are: (i) aspect-related variations in total solar radiation (influenced by the level of cloudiness) and its effect on ablation and diurnal variations in air temperature (i.e., morning-afternoon contrasts); and (ii) prevailing wind directions and their impact on the accumulation of snow (Derbyshire and Evans, 1976; Evans, 2006b). As a result (and as discussed below), cirque aspect can provide information about past variations in solar radiation and prevailing wind directions, but can also yield information about the extent of former glaciation.

\subsubsection{Cirque aspect and solar radiation}

The total receipt of incoming solar radiation on a given slope is strongly controlled by aspect, thereby explaining the tendency for many glaciers and cirques globally to have poleward orientations (Table 2 and Evans, 1977). Specifically, total solar radiation in the Northern Hemisphere is lowest on north-facing slopes; and on south-facing slopes in the southern hemisphere. This pattern results in lower air temperatures on poleward-facing slopes (Andrews, 1971; Evans, 1977), where the melting of accumulated snow and ice is therefore limited, and glaciers have a tendency to develop (Coleman et al., 2009). By contrast, equator-facing slopes receive high levels of total insolation, and are therefore climatically unfavourable for glacier development. This results in significant contrasts between the number of north and south-facing glaciers and cirques in many areas globally (Evans, 1977). The strength of aspect-related contrast in the total receipt of direct solar radiation received on particular slopes is greatest in areas of steep topography and, most importantly, in regions characterised by clear skies during the ablation season, since clouds limit the total receipt of direct solar radiation the Earth surface (Evans, 1977; Nelson 1998). This has led some to infer that where cirque aspects show a particularly strong poleward bias, former cirque glaciers likely developed under comparatively dry and, therefore, cloud-free ablation season conditions (Evans, 1977, 1990, 2006b). Arguably though, an even stronger indication of cloud-free conditions is when cirques (and glaciers) are found to have a NNE orientation in the Northern hemisphere, or SSE in the Southern hemisphere (Table 2) (Andrews and Dugdale, 1971; Trenhaile, 1976; Embleton and Hamann, 1988). Specifically, under cloud-free ablation season conditions, NNE-facing slopes in the Northern Hemisphere, and SSE-facing slopes in the Southern Hemisphere receive much of their direct solar radiation in the morning, when air temperatures are relatively low (Evans, 1977, 2006b). This limits ablation, and thereby favours glacier survival and associated cirque development. By contrast, on slopes that receive much of their direct solar radiation later in the day (e.g. on NW-facing slopes in the Northern Hemisphere), air temperatures are higher, and ablation is therefore increased, limiting glacier survival and cirque development (Evans, 2006b). In cloudy environments, or where there is convective afternoon cloudiness (common in tropical climates), these diurnal variations in temperature are reduced, and the propensity for glaciers, and thereby cirques, to face NNE and SSE (in the Northern and Southern Hemispheres, respectively) diminishes (Evans, 1977). As a result of these trends, cirque aspect has been used as a proxy for former cloudiness (e.g., Evans, 1990, 2006b; Barr and Spagnolo, 2013). This is particularly useful, since palaeo cloud-cover is a climatic variable for which there are few other indicators (Evans, 2006b).

\subsubsection{Cirque aspect and palaeo wind directions}


Prevailing wind directions are known to regulate where permanent snow patches and eventually glaciers and cirques are able to form (Evans, 1977). Specifically, there is a propensity for glacier growth in the lee of prevailing winds (Sanders et al., 2013). This reflects the fact that windward slopes are often blown free of accumulating snow, and turbulence on such slopes increases heat exchange and promotes ablation (Evans, 1977, 1990). By contrast, lee-side slopes not only protect accumulating snow (i.e., limiting deflation), but also receive redistributed snow blown from adjacent windward slopes and plateaus. Since the propensity for glacier development (and by extension cirque formation) on leeward slopes is maximised where there is a clear dominant wind direction, cirque aspect can theoretically be used as an indicator of prevailing palaeo wind directions (Hassinen, 1998; Mîndrescu et al., 2010; Kř́žžek and Mida, 2013). For example, the tendency for mid-latitude cirques to face eastward (Table 2 ) is considered to reflect glacier growth and survival in the lee of westerly winds which dominate at these latitudes (Evans, 1977; Benn, 1989). A more localised example comes from Kamchatka, where a peak in the frequency of NNW-facing cirques, despite a vector mean of $006^{\circ}$ (Table 2), has been attributed to former cirque glacier growth in the lee of SSE, snow-bearing winds from the North Pacific (Barr and Spagnolo, 2013). In this instance, the assertion that cirque aspects reflect palaeo wind directions is supported by modern conditions, as SSE winds currently dominate, and have determined that presentday Kamchatkan glaciers favour NNW orientations (Evans, 2006b).

Where cirques show a strong tendency towards directions which appear to coincide with prevailing winds (i.e., where they don't clearly reflect variations in direct solar radiation-discussed in section 4.3.1.; or are due to other factors such as geology-discussed in section 7.1.2), this might indicate that former glacier survival (and therefore mass balance) was governed by accumulation. Specifically, regional sheltering, possibly combined with the supply of redistributed snow and ice from surrounding slopes may have allowed glaciers to form even on climatically unfavourable (or less favourable) slopes, where the total receipt of direct solar radiation is likely to have been high. Such glaciers may have experienced considerable mass loss through melting, and, if replenished by snowfall and redistributed snow and ice, may have been particularly dynamic (with steep mass balance gradients). By contrast, where cirque aspects appear not to reflect palaeo winds, but instead reflect variations in direct solar radiation (e.g., where cirques face poleward), this might indicate that palaeo winds were rarely strong, or consistent, enough to result in the preferential formation of glaciers on leeward slopes, and that the survival of former glaciers was a result of limited ablation. Specifically, limited direct solar radiation (or receiving direct solar radiation in the morning) may have allowed glaciers to form and persist, even if total accumulation was minimal. Thus, the total mass-flux of such glaciers is likely to have been limited and they are unlikely to have been particularly dynamic (an effect likely counteracted by the duration of glacier cover on such slopes). Despite this, it should be kept in mind that in some regions (e.g., S. Alaska) dominant snow-bearing winds blow poleward, strengthening insolation based asymmetry (I.S. Evans, personal communication). Such examples serve to illustrate that though, above, we make a distinction between the controls exerted on cirque aspect by solar radiation and wind directions, in reality these factors can act together or against one another to magnify or limit trends. Where both controls had a considerable impact, separating them is not trivial (particularly if no information on palaeo-wind direction and/or cloud cover is available), but remains a possibility (Coleman et al. 2009).

\subsubsection{Cirque aspect and palaeoglaciation extent}

In addition to reflecting variations in solar radiation and prevailing wind directions (as outlined in sections 4.3.1., and 4.3.2,), it has been suggested that the strength of cirque aspect asymmetry in a particular region (i.e., the propensity for cirques within a population to have a preferred orientation-as recorded by cirque aspect vector strength) is partly a reflection of the extent of former glaciation (Evans, 1977; Nelson, 1998; Nelson and Jackson, 2003). This relates to the 'law of decreasing glacial asymmetry with increasing glacier cover' (Evans, 1977), which states that when glaciation is marginal (i.e., when peaks lie just above regional ELAs), glaciers can only form (and erode cirques) on climatically-favourable slopes. By contrast, during more extensive periods of glaciation (when peaks are far above regional ELAs), glaciers can also form (and erode cirques) on slopes which are climatically less favourable (see Evans, 1990, for examples from modern glaciers). As a result of this relationship, it has been argued that in regions where former glaciation was extensive, cirques are found to have a range of aspects (i.e., vector strength is low), whereas in regions where glaciation has been marginal, cirques show a strong aspect bias (i.e., vector strength is high). Evans, (1974, 1977), illustrates this effect in British Columbia, where cirque vector strength ranges from $95 \%$ in the marginally glaciated mountains of the Interior, to $55 \%$ closer to the coast, where the former ELA was lower; and similar trends are found in other mountain regions globally (e.g., in Northern Scandinavia: Hassinen, 1998). The law of decreasing glacial asymmetry with increasing glacier cover is widely considered to explain decreasing cirque aspect asymmetry (as reflected by a reduction in vector strength) with population altitude (Fig. 11) (Olyphant, 1977) and, to a lesser degree, latitude (Benn and Evans, 2010). At its most extreme, this law might explain why, in some areas, cirques are only present on one side of a mountain range. However, it is noted that in some places (as in Fig. 7b), there isn't always accommodation space to allow glaciers to develop and erode cirques on both sides of a mountain divide (see section 7.1.1.), limiting our ability to conclusively link this aspect asymmetry to the extent of former glaciation. Another consideration is that several sub-populations of cirques may be present in a single area (see section 7.3.). In such circumstances, several generations of cirques, each relating to different periods and palaeoclimates, may result in decreased aspect asymmetry (Benn and Evans, 2010).

\section{Cirque floor altitude \\ 5.1. Definition and measurement}

A number of measures are used to define the altitude of a cirque. These include the maximum altitude of the cirque crest (top of the headwall) (e.g., Mîndrescu and Evans, 2014); the crest altitude coinciding with the cirque's median axis (e.g., Bathrellos et al., 2014) (see section 4.1.); and the mean altitude of the entire cirque (e.g., Federici and Spagnolo, 2004). However, the measure most commonly used is cirque floor altitude, which is taken as the minimum floor altitude, the modal floor altitude, or the minimum altitude of the cirque threshold (e.g., Andrews and 
Miller, 1972; Evans and Cox, 1995). Traditionally, cirque floor altitude was measured in the field (e.g., de Martonne, 1900), but is now extracted directly from topographic maps (e.g., Evans and Cox, 1995; Evans, 2006a), or more commonly from DEMs (e.g., Principato and Lee, 2014; Seif and Ebrahimi, 2014). Extracting values directly from topographic maps or DEMs is likely to overestimate real altitudes (somewhat), as the depth of sediment or water in a cirque is not taken into consideration (see section 7.2.2).

In order to understand regional trends in cirque floor altitudes, linear, quadratic, or cubic trend surfaces, plotted in two- (e.g., Hassinen, 1998; Anders et al., 2010) or threedimensions (e.g., Peterson and Robinson, 1969; Anders et al., 2010), are often generated (e.g., Fig. 12). Sometimes entire cirque populations are plotted (e.g., Linton, 1959; Hassinen, 1998) or, because of considerable variability (i.e., 'noise') in cirque floor altitudes, it may be necessary to focus on a subsample of cirques, perhaps of a particular type or within a particular region (e.g., Davies, 1967; Derbyshire, 1963; Evans, 1999).
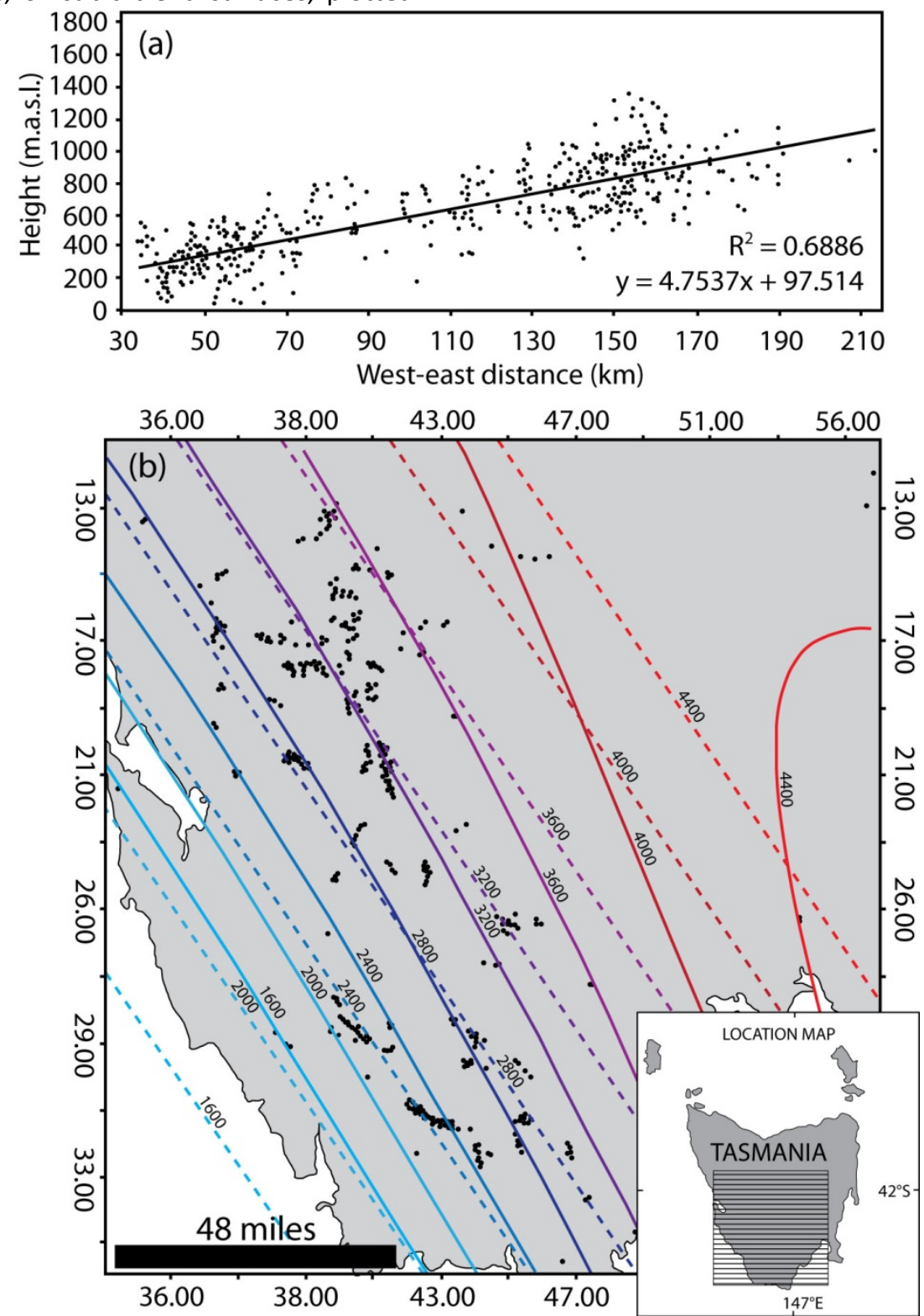

Fig. 12. (a) Trends in cirque floor altitude along a $210 \mathrm{~km}$ transect across Northern Scandinavia (image redrawn from Hassinen, 1998). (B) Linear (dashed lines) and quadratic (solid lines) cirque floor altitude trend surfaces across SW Tasmania. Black dots are mapped cirques. Figure modified from Peterson and Robinson (1969).

\subsection{Common trends in cirque floor altitude}

One key aspect about cirque floor altitudes is that they can vary considerably, even within a single mountain range (Flint, 1957; Anders et al., 2010). They are also often found to increase inland (e.g., Fig. 12), likely reflecting the role of precipitation in regulating the altitude of former glaciers (e.g., Peterson and Robinson, 1969; Hassinen, 1998; Principato and Lee, 2014; Barr and Spagnolo, 2015). In general, cirque floor altitudes decrease with increasing latitude, as low latitude glaciers can only develop at high altitudes (Mitchell and Humphries, 2015) (Fig. 13). Cirque floor altitudes also tend to vary as a function of cirque aspect, with poleward-facing cirques found at lower altitudes than those on less climatically favourable slopes (Evans, 2006a) (Fig. 14a)though this trend is not ubiquitous (Evans, 1999; Evans and Cox, 1995). 


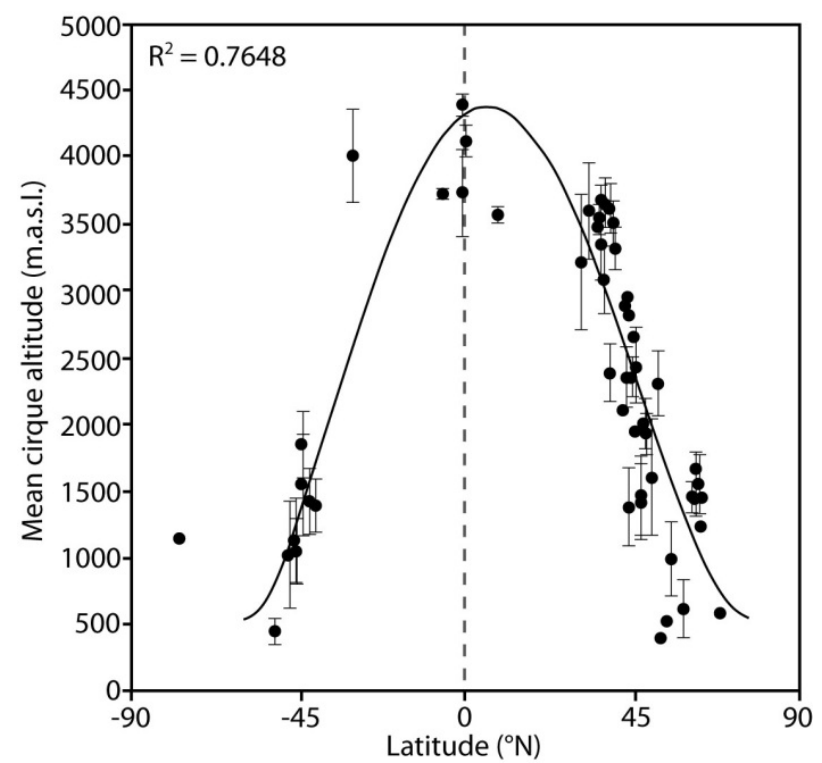

Fig. 13. Variations in mean cirque floor altitude with latitude for 56 globally distributed cirque populations (total number of cirques $>14,000)$. Error bars reflect one standard deviation. The solid black line reflects a polynomial (fourth-order) trend. All data are from Mitchell and Humphries (2015).
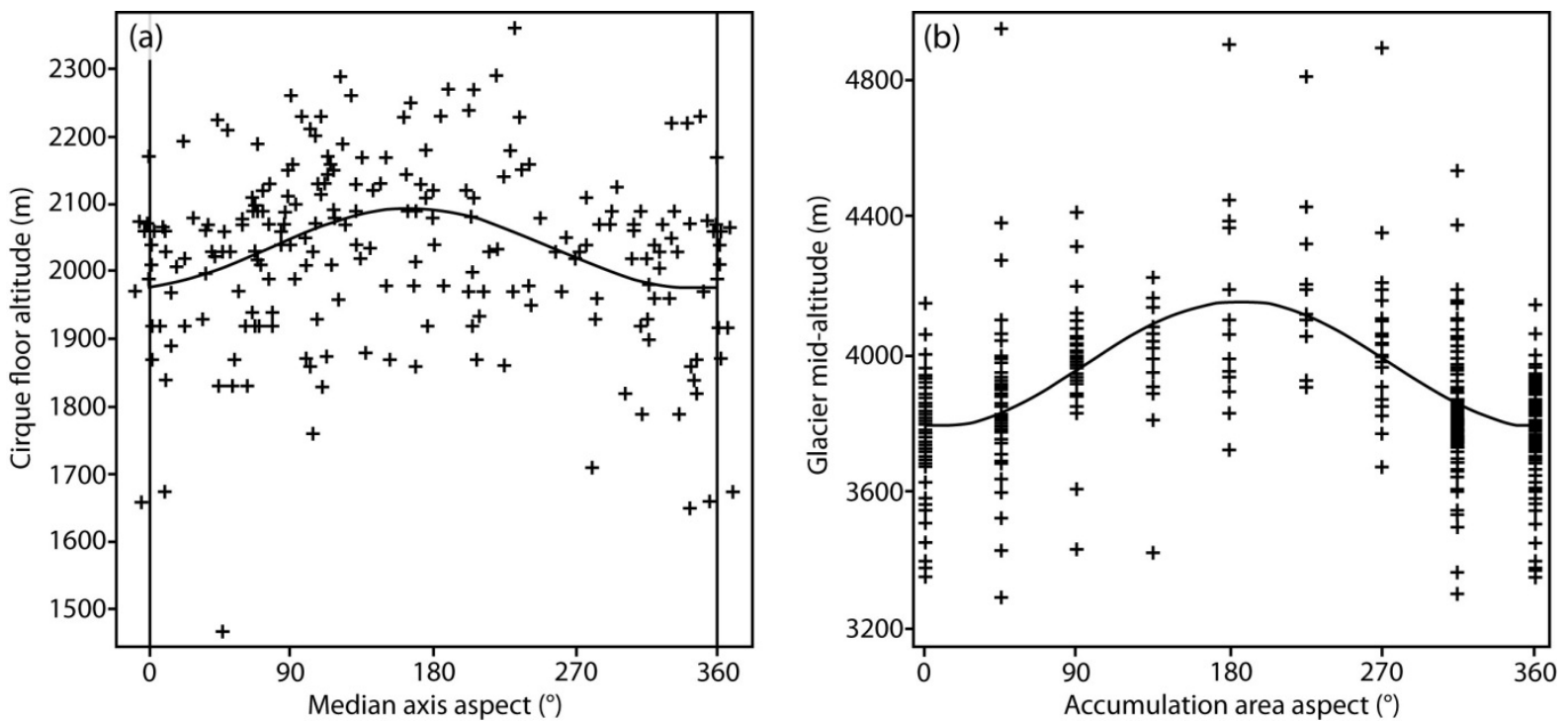

Fig. 14. (a) Cirque floor altitude plotted against median axis aspect for cirques in the Făgăraş Mountains $\left(45.60^{\circ} \mathrm{N}, 24.74^{\circ} \mathrm{E}\right), \mathrm{Romania}$ Cirques facing $346^{\circ}$ (NNW) are $113 \mathrm{~m}$ lower than those facing $166^{\circ}$ (SSE). The fitted line is a regression of altitude on sine and cosine of aspect (Evans and Cox, 2005). Figure redrawn from Mîndrescu et al. (2010). (b) Glacier mid-altitude plotted against accumulation area aspect for 469 modern glaciers in Bogdo Ula (Xinjiang, $49.12^{\circ} \mathrm{N}, 87.82^{\circ} \mathrm{E}$ ). This figure illustrates that glacier altitude is lowest for those facing north. Figure redrawn from Evans (2006b).

\subsection{Cirque floor altitudes as a palaeoenvironmental indicator}

Cirque floor altitudes can vary as a function of lithology, structure and topography (see section 7.1.1.), and intra-regional variability is also likely to be influenced by the number and variety of Quaternary glaciations in a given area (see section 7.3). Despite this, cirque floor altitudes are also governed by palaeoclimate-that is, glaciers can only generate cirques at an altitude where snow and ice can accumulate and persist interannually (as outlined in section 2.2.). As a result, cirque floor altitudes have been used as palaeoenvironmental indicators (e.g., Linton, 1959; Davies, 1967; Principato and Lee, 2014). Specifically, they have been used to analyse (i) palaeoprecipitation patterns; (ii) palaeo ELAs; (iii) landscape development; (iv) palaeo cloud-cover; and (v) palaeoglaciation extent. These factors are discussed below.

\subsubsection{Cirque floor altitudes and palaeoprecipitation patterns}

In many environments, regional trends in the altitude at which glaciers are able to form (and thereby erode cirques) are driven by moisture availability (i.e., the supply of snow) (Benn and Evans, 2010). As a result, regional variations in cirque floor altitudes are often considered to reflect palaeoprecipitation gradients which existed during former periods of glaciation (e.g., Peterson and Robinson, 1969; Hassinen, 1998; Principato and Lee, 2014; Barr and Spagnolo, 2015). For example, Peterson and Robinson (1969), found evidence of an inland increase in cirque floor altitudes across SW Tasmania (Fig. 12b). They used this trend to argue that Pleistocene precipitation totals must have decreased towards the east (as at present), but also recognise that cirque floor altitudes follow the overall topographic trend, 
leading to the consideration that other factors, including spatial variability in lithology and structure, may partly explain observed trends. Similarly, across northern Scandinavia, Hassinen (1998) found cirque floor altitudes (along a $210 \mathrm{~km}$ transect) to increase inland (from west to east), with a gradient of $\sim 4.75 \mathrm{~m} \mathrm{~km}^{-1}$ (Fig. 12a). This trend was attributed to an inland decrease in palaeoprecipitation, driven by prevailing winds from the W/SW, combined with the influence of topography (i.e., the heights of the local mountains gradually increase towards the east, but at a slower rate than the increase in cirque floor altitudes). Evans (1999) analysed cirque floor altitudes across Wales, and found that cirque floors are lower in south wales than in the north, despite the currently lower precipitation and slightly higher temperature for a given altitude and exposure. This would seem to imply that during cirque formation, there was a greater increase in snowfall (relative to present) in south than in north Wales. Evans (1999) suggested two possible explanations for this trend: (i) icy conditions and/or lower sea level in the Irish Sea and Cardigan Bay during former periods of glaciation (limiting snowfall in North Wales); and (ii) an increase in the importance of winds from the south during former periods of glaciation. Such winds were likely moisture-starved by the time they reached north Wales (explaining limited snowfall in this area), but may have brought precipitation to south Wales. As part of this study, Evans (1999) also used cirque floor altitudes to calculate palaeoglaciation levels (based on a modification of the 'glaciation level' defined by $\emptyset$ strem et al., 1981) across Wales. This involved calculating the highest cirque-free and lowest cirque-occupied crests (a summit, shoulder or gently sloping ridge) within a given area. The purpose was to analyse spatial variability in the minimum altitude required to allow cirque formation. Evans (1999) found that trends in palaeoglaciation level followed trends in cirque floor altitudes (though the former are higher than the latter), and argued that when making links to palaeoclimate, palaeoglaciation level has an advantage over cirque floor altitudes, as it is based on additional evidence (i.e., cirque absence as well as presence is considered). Evans (1999) suggested that where there is considerable local variability in cirque floor altitudes (as is often the case), palaeoglaciation level can be used to test any apparent trends (i.e., it is a way of simplifying/sub-sampling a complex cirque record). Despite this utility, palaeoglaciation levels are rarely calculated (c.f. Evans, 1999; Mîndrescu et al., 2010), perhaps because the approach is time consuming and can be difficult to apply where mountain summits are rounded, connected and/or in regions of plateau topography (Evans, 1999).

\subsubsection{Cirque floor altitudes and palaeo ELAs}

As noted in section 5.3.1., climate is the key control on the altitude at which glaciers initiate, and is therefore a key control on cirque floor altitudes. This means that the regional climatic ELA (governed by temperature and precipitation) during former periods of glacier initiation governs cirque floor altitudes. As a result of this association, cirque floor altitudes have been used as a proxy for ELAs during former periods of glaciation (e.g., Porter, 1964, 1989; Williams, 1975; Pelto, 1992). Some have used cirque floor altitudes directly (e.g., Meierding, 1982; Benn and Lehmkuhl, 2000; Mitchell and Montgomery, 2006), whilst others have estimated ELA using a ratio between the minimum altitude of the cirque threshold and the maximum altitude of the cirque headwall (i.e., the toe-to-headwall altitude ratio method: THAR) (e.g., Principato and Lee, 2014). The resulting ELA estimates (derived in either of these two ways) are typically considered to reflect conditions when glaciers were comparatively small, and confined to their cirques (Evans, 1999) (as in Fig. 5a). For example, in the North Cascades, the floor altitudes of cirques are estimated to lie about $50 \mathrm{~m}$ below the ELA of former cirque glaciers (Porter, 1989). However, cirques are typically formed over multiple glacial cycles, and because of difficulties with establishing a chronology for cirque occupation (see section 8.3), it is difficult to assign these ELA estimates to any particular phase (c.f., Principato and Lee, 2014). For this reason, cirque floor altitudes should be assumed to reflect a 'composite' Pleistocene snowline (or ELA)-reflecting the fact that cirques are often a composite product of numerous glacial stages (Flint, 1957; Porter, 1964). This idea, and the associated terminology, has been adopted in a number of investigations (e.g., Peterson and Robinson, 1969; Locke, 1990; Augustinus, 1999), but has more recently been extended to suggest that cirque floor altitudes reflect the 'average' or 'mean' Quaternary ELA (e.g., Mitchell and Montgomery, 2006; Foster et al., 2008; Mitchell and Humphries, 2015). However, the term 'composite' seems more appropriate when talking about cirque floor altitudes in general, since this avoids the statistical connotations associated with 'average' or 'mean'. The term 'mean' or 'average' ELA is certainly inappropriate when applied at a global scale (c.f., Mitchell and Humphries, 2015), since ELA variations during the Quaternary have been so spatially and temporally variable (Evans et al., 2015).

Given that cirque floor altitudes are considered to reflect former ELAs, one way in which quantitative palaeoclimatic data is sometimes obtained is through comparison with modern ELA values (e.g., Anders et al., 2010). For example, Principato and Lee (2014) assume a lapse rate of $0.6^{\circ} \mathrm{C} 100 \mathrm{~m}^{-1}$, and suggest that a temperature drop of only $0.6^{\circ} \mathrm{C}$ would be required for the majority of cirques in Vestfirðir, NW Iceland, to be ice covered. Despite this approach, it must be kept in mind that no unequivocal palaeotemperature solution can be found unless the period of cirque occupation is known, and precipitation during this period can be constrained by other proxy data (Principato and Lee, 2014). It has also been emphasised (e.g., Benn and Lehmkuhl, 2000) that cirque floor altitudes bear no real relationship to the concept of ELA as applied to modern glaciers, but simply serve to summarise some characteristics of a glaciated catchment. As a result, Benn and Lehmkuhl (2000) suggest that cirque floor altitude be referred to as a glacier elevation index, though this terminology has not been widely adopted, and the term ELA continues to be used in this context-though not without controversy (e.g., Evans et al., 2015).

\subsubsection{Cirque floor altitudes and landscape development}

Cirque floor altitudes have been used to analyse the role of glaciers in regulating landscape development, based on the idea that glacial erosion is maximised at the ELA (where ice discharge and velocity are greatest) (MacGregor et al., 2000; Mitchell and Montgomery, 2006). Thus, when a region is occupied by large glaciers, and the ELA is located below cirque floor altitudes, a region's overall relief is increased as the zone of maximum subglacial erosion is focused in a zone beyond cirque confines (e.g., Fig. 5b), and deep glacial valleys are incised (Oskin and Burbank, 2005; Valla et al., 2011). By contrast, during periods of cirque type glaciation, this zone of maximised subglacial 
erosion is focused within a cirque (Fig. 5a), and vertical incision and particularly headward erosion cause the steepening and failure of slopes above cirque floors (Mitchell and Montgomery, 2006; Anders et al., 2010; Champagnac et al., 2012). As a result, cirque glacier erosion might effectively limit peak altitudes, as there is a quick drop off in land surface area above cirque floors. Evidence in support of this suggestion comes from the fact that, when analysed across a region, cirque floor altitudes and maximum altitudes of mountains (i.e., peak altitudes) are often found to co-vary (e.g., Fig. 15), with the former typically a couple of hundred metres below the latter (Mitchell and Montgomery, 2006; Mîndrescu and Evans, 2014). This pattern, has been referred to as the 'buzzsaw signature', and is considered to reflect the role of glacial erosion in limiting peak altitudes (Brozović et al., 1997; Mitchell and Montgomery, 2006; Egholm et al., 2009)-something which, some have suggested, can keep pace with any modern tectonic uplift rate (Brozović et al., 1997; Brocklehurst and Whipple, 2007). Examples of regions where this signature has been identified include the Cascade Mountains (Mitchell and Montgomery, 2006), the Basin and Range (Foster et al., 2008), the European Alps (Anders et al., 2010), the southern Sredinny Mountains, Kamchatka (Barr and Spagnolo, 2014), and at a global scale (Mitchell and Humphries, 2015). The presence and/or absence of this buzzsaw signature has been used, in some cases, as an indicator of the role played by glaciers in regulating mountain topography-and by extension has been used as a palaeoenvironmental indicator (based on the assumption that palaeoenvironmental conditions, at least partly, govern a glacier's ability to erode, and thereby limit, topography).
Specifically, the occurrence of the buzzsaw signature has been used to infer the former presence of dynamic (hence particularly erosive) and/or long-lasting cirque glaciers; and/or comparatively symmetric glaciation, where former glaciers have been able to erode peaks and intervening ridges from all sides (Mîndrescu and Evans, 2014). Conversely, the absence of the buzzsaw signature has been used to infer the former presence of cold-based (Stern et al., 2005; Thomson et al., 2010), short-lived and/or asymmetric (in terms of their aspects) glaciers (Mîndrescu and Evans, 2014), and has been used to indicate that former glaciers rapidly grew beyond cirque confines, and focused erosion further downvalley (Barr and Spagnolo, 2014). The absence of a buzzsaw signature has also been used as an indication that a region has undergone considerable Quatemary uplift (able to outpace denudation via the glacial buzzsaw) or that considerable time has elapsed since deglaciation (Egholm et al., 2009).

However, the importance of the buzzsaw signature is still debated (Hall and Kleman, 2014) and its presence might simply reflect the fact that cirques are located near mountain summits, and appear to have a limited vertical height range (Mîndrescu and Evans, 2014). Regional variations in rock mass strength and slope steepness are also confounding factors when attempting to make palaeoenvironmental inferences from the presence/absence of a buzzsaw signature. Specifically, the lack of a clear buzzsaw signature may indicate that bedrock strength has restricted subglacial erosion or that slopes have been too steep to allow erosive glacial ice to accumulate (Ward et al., 2012; Godard et al., 2014).

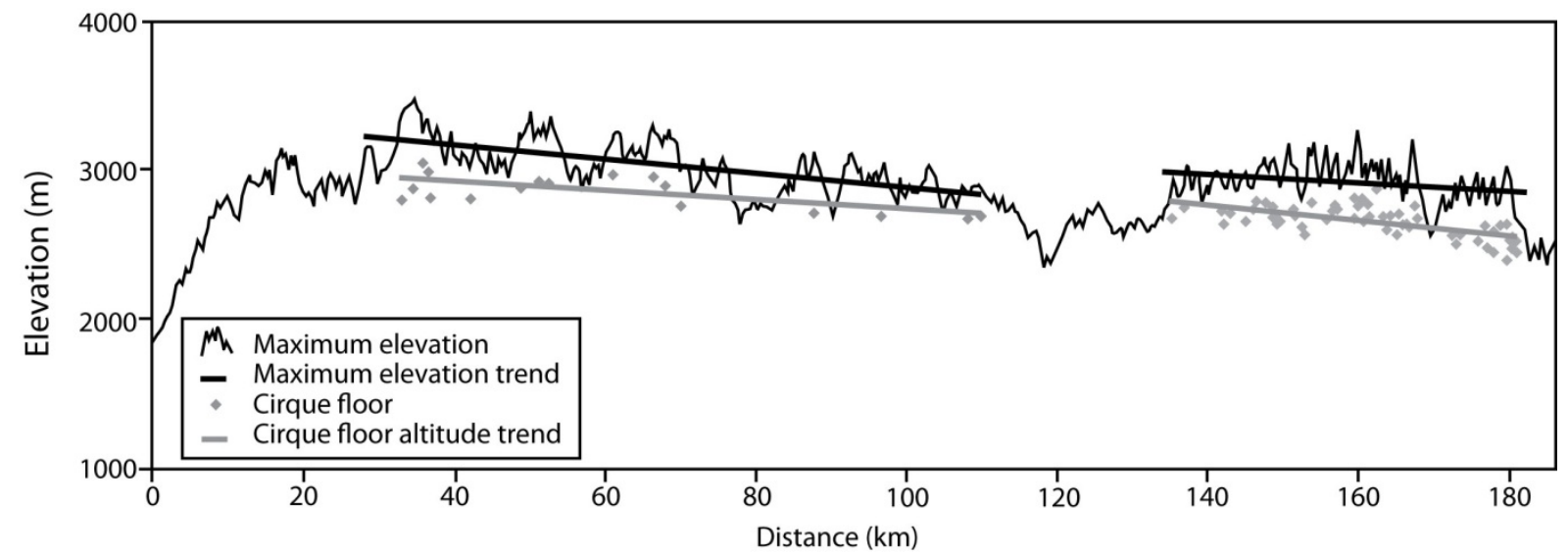

Fig. 15. Elevation profile along the Beaverhead-Bitterroot Mountains (northern Basin and Range, USA), illustrating how cirque floor altitudes co-vary with peak altitudes. Figure modified from Foster et al. (2008).

\subsubsection{Cirque floor altitudes and palaeo cloud-cover}

As noted in section 4.3.1., cirque aspect asymmetry can potentially provide information about palaeo cloud-cover. In a similar way, aspect-related variations in cirque floor altitude can potentially be used as an indicator of palaeo cloudiness (Evans, $2006 \mathrm{~b})$. Again, this is based on the assumption that variations in the receipt of direct solar radiation at the Earth surface govern where glaciers are able to form (and thereby erode cirques) (Evans, 2006b). Specifically, glaciers, and therefore cirques, are less likely to form on climatically unfavourable slopes, and those that do might be restricted to higher altitudes than on climatically favourable slopes (i.e., the cooler conditions at higher altitude are necessary to compensate for increased melting in response to greater direct solar radiation). This trend is certainly seen for many modern glaciers (Evans and Cox, 2005; Evans, 2006b), which are often found at lower altitudes when on climatically favourable (i.e., poleward-facing) slopes (Fig. 14b). Again, this relationship is considered to be intensified under clear skies, when aspect-related contrasts in the total receipt of direct solar radiation are greatest (see section 4.3.1.). As a result, aspectrelated variations in cirque floor altitudes (or lack thereof) have been used as a proxy for palaeo cloud-cover. For example, Barr and Spagnolo (2013) used this idea to argue that comparatively cloud-free conditions prevailed during former periods of glaciation on the Kamchatka Peninsula (i.e., there are notable aspect-related variations in cirque floor altitudes). Similarly, Evans (2006b), noted that in SW British Columbia, the predicted differences in altitude between north- and south-facing cirques 
are 194 and $220 \mathrm{~m}$, for the Bendor and Cayoosh Ranges respectively (predictions based on Fourier regression of cirque altitude against aspect). Again, this is assumed to reflect comparatively clear skies during former periods of glaciation. By contrast, in regions such as Wales (Evans, 1999) and the English Lake District (Evans and Cox, 1995), there is limited evidence of aspect-related variation in cirque floor altitudes (i.e., Fourier regressions of cirque floor altitudes on aspect are insignificant for both populations), suggesting glaciation and cirque development under comparatively cloudy (overcast) conditions (Evans, 2006b).

\subsubsection{Cirque floor altitudes and palaeoglaciation extent}

As noted in section 4.3.3, the strength of cirque aspect asymmetry has been used as an indicator of palaeoglacier extent, based on the 'law of decreasing glacial asymmetry with increasing glacier cover' (Evans, 1977). In a similar way, aspectrelated variations in cirque floor altitude can indicate palaeo ice extent. Specifically, in regions where aspect-related variations in cirque altitude are notable (e.g., Fig. 14a), former glaciation is sometimes assumed to have been marginal, as low altitude glaciers were only able to develop, and form cirques, on climatically favourable slopes (Barr and Spagnolo, 2013). By contrast, in regions where former glaciation was extensive (i.e., where peaks extended far above regional ELAs), glaciers were able to form and erode cirques at comparatively low altitudes, even on climatically unfavourable (or less favourable) slopes.

\section{Cirque morphometry}

\subsection{Definitions and measurements}

Morphometry is the quantitative analysis of size and shape, and is widely used to analyse glacial landforms, particularly since the widespread adoption of GIS and remote sensing techniques (Evans, 2012). The first detailed and statistical analysis of cirque morphometry was conducted by Andrews and Dugdale (1971), and such analyses have been the focus of many subsequent investigations (e.g., Evans and Cox 1995; Evans, 2006a, 2009). The analysis of cirque morphometry is often aimed at understanding the processes and mechanisms responsible for cirque development (outlined in section 2.2), and, as a result, has been used to obtain palaeoenvironmental information (e.g., Steffanová and Mentlík, 2007; Kř́ižek and Mida, 2013; Seif and Ebrahimi, 2014). When used for this purpose, there are a number of morphometric attributes commonly analysed. These are listed in Table 3, and discussed in detail below.

Table 3. Attributes commonly measured when analysing cirque morphometry

\begin{tabular}{|c|c|}
\hline Attribute & Different measures \\
\hline \multicolumn{2}{|l|}{ Length (L) } \\
\hline \multicolumn{2}{|l|}{ Width (W) } \\
\hline \multirow[t]{4}{*}{ Altitudinal range } & Height range $(\mathrm{H})$ \\
\hline & Amplitude (Amp) \\
\hline & Headwall height \\
\hline & Floor altitudinal range \\
\hline \multicolumn{2}{|c|}{ Shape ratios $(\mathrm{L} / \mathrm{W}, \mathrm{L} / \mathrm{H}, \mathrm{W} / \mathrm{H})$} \\
\hline \multicolumn{2}{|l|}{ Circularity (circ.) } \\
\hline \multicolumn{2}{|l|}{ Size (3VLWH) } \\
\hline \multicolumn{2}{|l|}{ Planimetric Area (A) } \\
\hline \multirow[t]{5}{*}{ Slope gradient (S) } & Cirque mean \\
\hline & Axial gradient \\
\hline & Minimum floor \\
\hline & Maximum headwall \\
\hline & Longitudinal profile \\
\hline \multirow[t]{2}{*}{ Closure } & Plan \\
\hline & Profile \\
\hline
\end{tabular}

\subsubsection{Cirque length}

Cirque length $(L)$ is typically defined as the length of the median axis (which splits the cirque into two exactly equal halves) (Fig. 8b, and section 4.1) (Evans and Cox, 1995), and can be measured using automated GIS techniques (e.g., Federici and Spagnolo, 2004). In some cases, this definition is modified slightly. For example, Olyphant (1981) defines cirque length as the length of the line joining the cirque threshold to the headwall midpoint (i.e., in this instance, the cirque is not necessarily split into two equal halves).

\subsubsection{Cirque width}

Cirque width (W) is typically defined as the longest line perpendicular to the median axis (Fig. 8b) (Evans and McClean, 1995). However, as with cirque length, there is some variation in how exactly width is defined and measured. Olyphant (1981), for example, calculates width using the average of four measurements equally spaced along, but perpendicular to, the length axis.

\subsubsection{Cirque altitudinal range}

Cirque altitudinal range has been defined and measured in a variety of ways. Perhaps the simplest way is to measure the vertical distance between the lowest and highest point within a cirque (Fig. 8d). This measure is most commonly referred to as height range $(H)$ (Evans, 2009; Seif and Ebrahimi, 2014). A cirque's altitudinal range can also be defined by its amplitude (Amp), which is the vertical distance from the lowest point of the cirque threshold to the top of the median axis (i.e., the altitude at the point where the median axis intercepts the cirque crest) (e.g., Evans, 2009; Mîndrescu and Evans, 2014) (Fig. 8d). Other measures of cirque altitudinal range include the vertical distance between the cirque's minimum altitude and the altitude at the top of the median axis; the vertical distance between the lowest point on the cirque threshold (the minimum floor altitude for non-overdeepened cirques) and the highest point on the cirque crest; the vertical distance between the lowest point on the cirque threshold and the average cirque crest altitude; and the greatest vertical distance between the cirque floor and headwall crest, measured along any single slope line, perpendicular to 
slope contours (this is a measure of headwall height) (Evans and Cox, 1995; Evans, 2009). Despite these subtly different measures, for the sake of simplicity, in this paper, ' $\mathrm{H}$ ' is used to denote cirque altitudinal range, however defined.

\subsubsection{Cirque shape ratios and circularity}

Ratios of length to width (L/W), and both length and width to altitudinal range $(\mathrm{L} / \mathrm{H}$ and $\mathrm{W} / \mathrm{H}$, respectively) are often calculated for individual cirques (e.g., Graf, 1976; Seif and Ebrahimi, 2014). The L/W ratio defines the planimetric shape of a cirque, that is, whether a cirque is wider than long $(L / W<1.0)$, longer than wide (L/W > 1.0), or approximately circular (L/W 1.0). The $L / W$ ratio is often considered alongside an independent measure of circularity, defined as the ratio between the perimeter of a cirque and the perimeter of a circle with the same area (Aniya and Welch, 1981). Both L/H and W/H are considered measures of cirque incision, with lower values indicating greater incision (Bathrellos et al., 2014). The $\mathrm{L} / \mathrm{H}$ ratio is also a measure of cirque steepness (Federici and Spagnolo, 2004), though more complex steepness measures are outlined in section 6.1.7.

\subsubsection{Cirque size}

Though cirque length, width and altitudinal range each contribute to cirque size, it can be useful to have a single measure of this 'size'. One approach, which takes all three orthogonal dimensions into account, is to consider cirque 'volume' (e.g., LWH) (Olyphant, 1981; Evans, 2006a). However, Mîndrescu and Evans (2014) emphasise that this measure has been found less amenable to statistical analysis than a definition of cirque size as the cube root of volume (i.e., ${ }^{3} \mathrm{VLWH}$ ), which has now become the most commonly used parameter (Evans, 2006a; Barr and Spagnolo, 2013; Delmas et al., 2015). Often, cirque size is calculated in order to assess whether cirques have developed isometrically (i.e., whether the rate of growth has been equal in all three orthogonal dimensions) or allometrically (i.e., whether the rate of cirque lengthening, widening and deepening has been unequal, and cirques have therefore changed shape during development) (Olyphant, 1981; Evans, 2010). To assess this, length, width and altitudinal range are plotted against cirque size (i.e., ${ }^{3}$ VLWH) (e.g., Fig. 16). The power exponents (allometric coefficients) of logarithmic regressions of such plots must sum to 3.0 (since $L W H=$ size $^{3}$ ). If cirque growth is perfectly isometric, then power exponents for length, width and altitudinal range should each equal 1.0. By contrast, if one (or more) of the power coefficients is $>1.0$, then cirque growth can be assumed to have been allometric. This approach, which assumes the ergodic principle that spatial variation can be substituted for variation with time (see section 6.2.3.), was first outlined by Olyphant (1981) and developed by Evans (2006a).

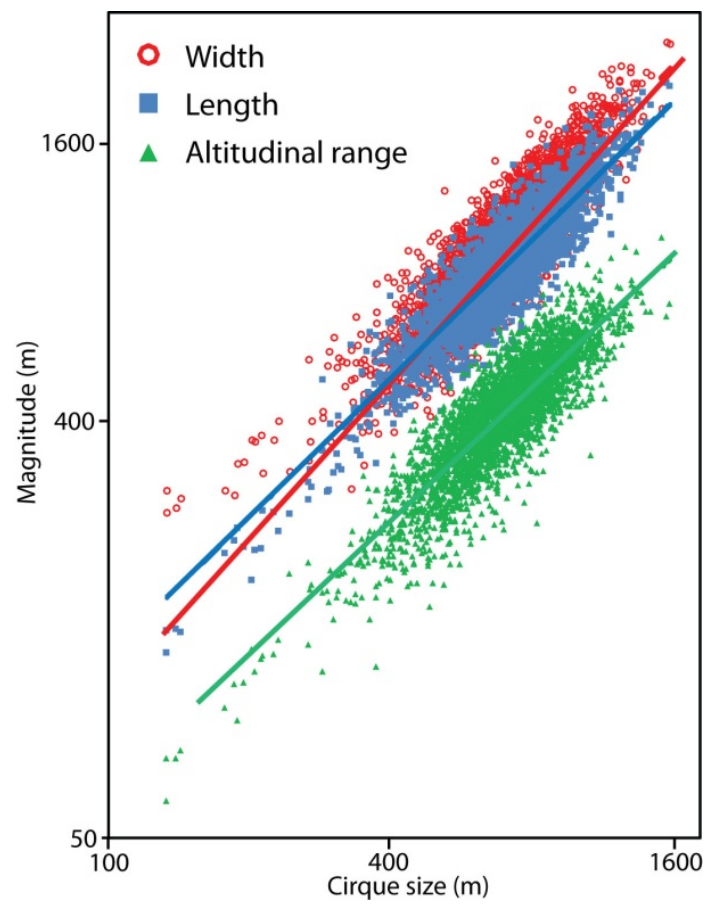

Fig. 16. Allometric (double logarithmic) plot of cirque length (L), width (W), and altitudinal range $(H)$, against cirque size $\left({ }^{3} \mathrm{VLWH}\right)$. In this instance, where the focus is on Kamchatkan cirques $(n=3520)$, the power exponent for $L$ is $1.00\left(R^{2}=0.82\right)$; for $W$ is $1.04\left(R^{2}=\right.$ $0.79)$; and for $\mathrm{H}$ is $0.96\left(R^{2}=0.75\right)$. Data from Barr and Spagnolo (2013).

\subsubsection{Cirque planimetric area}

Traditionally, calculating cirque planimetric area was a difficult and time consuming task (de Martonne, 1900; Evans and Cox, 1995), but can now be completed simply using GIS techniques (Federici and Spagnolo, 2004; Křížek and Mida, 2013; Bathrellos et al., 2014). In some instances, both the 2D and 'real' $3 D$ surface area are calculated, and the 3D/2D ratio, which depends on cirque gradient (or steepness/slope), is used as an indicator of overall cirque shape (e.g., Krrížek and Mida, 2013). Others calculate the area of the cirque floor rather than (or in addition to) the total cirque area (e.g., de Martonne, 1900), and calculate the ratio of the floor area to the total cirque area (e.g., Mîndrescu and Evans, 2014).

\subsubsection{Cirque gradient}

As noted in section 3.1., and illustrated in Fig. 8, land surface gradient (particularly breaks of slope) can help in the identification and delineation of cirques (Evans and Cox, 1995; Federici and Spagnolo, 2004). In addition, cirque gradient is often 
measured, on the assumption that it reflects the degree to which cirques have been modified (overdeepened) by glacial (and other) processes (Seif and Ebrahimi, 2014). Measuring cirque gradient was once particularly time consuming (e.g., de Martonne, 1900; Evans and Cox, 1995), but is now readily analysed from DEMs (e.g., Principato and Lee, 2014), and is measured in a variety of ways. This includes measuring the 'average' gradient of each cirque, automatically derived in a GIS as the mean of all slope angles of the DEM pixels that define the cirque (e.g., Barr and Spagnolo, 2013); the gradient of each cirque's median axis (i.e., $\arctan (\mathrm{Amp} / \mathrm{L})$ ), which is considered to approximate the surface gradient of a former glacier filling a cirque (Evans and Cox, 1995; Mîndrescu and Evans, 2014); and the minimum floor gradient and maximum headwall gradient of each cirque (used to calculate profile closure-see section 6.1.8.) (Evans and Cox, 1995). Longitudinal profiles are also sometimes plotted as a way of describing/illustrating overall cirque gradient and shape (e.g., Haynes, 1968; Graf, 1976; Kř́žek et al., 2012; Seif and Ebrahimi, 2014).

\subsubsection{Cirque plan and profile closure}

Plan and profile closure are measures of the degree of cirque concavity. Plan closure is typically defined as the range in aspect along a cirque's mid-height contour (i.e., mid-way between the minimum cirque altitude and the maximum crest altitude) (Gordon, 1977) or along a cirque's longest contour (Evans, 1969, 1974). This is typically calculated by analysing cirque aspect over specified sections of the contour (e.g., over $100 \mathrm{~m}$ intervals) in order to avoid minor topographic variations, such as gullies, which have a large impact on slope aspect (Evans and Cox, 1995). Profile closure is the difference between a cirque's maximum headwall and minimum floor gradient, and can be readily measured from DEMs (Evans and Cox, 1995; Mîndrescu and Evans, 2014). As the floor gradient is often close to 0 degrees, in many cases, profile closure corresponds to the maximum headwall gradient. As illustrated in Fig. 6, both plan and profile closure generally increase in response to cirque development, with well-developed cirques having high plan and profile closure (Evans and Cox, 1995; Evans, 2006a). As a result, plan and profile closure are considered the most obvious, directly measurable morphometric indicators of the degree of cirque development (Evans and Cox, 1995; Mîndrescu and Evans, 2014). Some have also calculated the plan closure of cirque floors to assess the degree to which cirque headwalls enclose cirque floors, which is again considered a measure of cirque development (Mîndrescu and Evans, 2014).

\subsection{Common trends in cirque morphometry}

Table 4. Morphometric data from a globally distributed sample of cirques. In each case, measures are recorded as min, mean and max. L, W and $\mathrm{H}$ are recorded in metres. Area is recorded in $\mathrm{km}^{2}$. Citations for each study: (1) Gómez-Villar et al (2015); (2) Bathrellos et al. (2014); (3) Delmas et al. (2014); (4) Mîndrescu and Evans (2014); (5) Principato and Lee (2014); (6) Seif and Ebrahimi (2014); (7) Barr and Spagnolo (2013); (8) Kř́žžek and Mida (2013); (9) Kř́žzek et al (2012); (10) Ruiz-Fernández et al (2009); (11) Hughes et al (2007); (12) Steffanová and Mentlík (2007); (13) Marinescu (2007); (14) Evans (2006a); (15) Richter (2006); (16) Federici and Spagnolo (2004); (17) Nelson and Jackson (2003); (18) Urdea (2001); (19) García-Ruiz et al. (2000); (20) Davis (1999); (21) Hassinen (1998); (22) Evans and Cox (1995); (23) Evans and McClean (1995); (24) Aniya and Welch (1981); (25) Gordon (1977).
In this section, some common trends in cirque morphometry are discussed, with data assimilated from a number of globallydistributed studies. The utility of this approach is that global patterns can be analysed; the weakness is that cirque attributes are often defined and measured in slightly different ways from study to study (as noted in section 6.1.). The common trends described below are not used here to directly infer palaeoenvironmental conditions, but indicate how variable cirque metrics can be.

\subsubsection{General trends in cirque morphometry}

In Tables 4 and 5, morphometric data from 10,362 globally distributed cirques, from 33 regional studies, are presented. In this dataset, cirque length and width are typically within the 100-1500 $\mathrm{m}$ range (Fig. 17). Mean cirque length and width are remarkably similar at 744 and $749 \mathrm{~m}$, respectively (based on regional means). Length and width are also remarkably similar within specific cirque populations, with the exception of cirques in New Hampshire (Davis, 1999) and the Dry Valleys, Antarctica (Aniya and Welch, 1981), which are significantly greater in length than width (Fig. 17a). Cirque altitudinal range has a mean of $309 \mathrm{~m}$ (based on regional means), though values are typically within the $150-600 \mathrm{~m}$ range (Fig. 17b). Based on the 30 regional studies from Table 4 where L/W ratios are provided (Fig. 17c), the mean value (based on regional means) is 1.03 , indicating that cirques are typically circular in planform. Measures of circularity also support this (with a mean of 1.02), though only seven of the studies listed directly measure circularity (Table 5). This circular shape appears to apply to small and large cirques alike (Federici and Spagnolo, 2004), suggesting that the circular shape of cirques develops even during the early stages of growth (assuming that the ergodic principle holds). Based on the 25 regional studies from Table 4 where $\mathrm{L} / \mathrm{H}$ ratios are reported, values are typically within the 1.5-4.0 range (Fig. $17 d$ ), with a mean of 2.58 (based on regional means). This would suggest that cirque length often exceeds altitudinal range. Based on the 18 regional studies from Table 4 where $\mathrm{W} / \mathrm{H}$ ratios are reported, values are typically within the $1.5-4.0$ range (Fig. 17d), with a mean of 2.72 (based on regional means) - suggesting that cirque width often exceeds altitudinal range. Of the cirques summarised in Table 4, the largest has a planimetric area of 9.8 $\mathrm{km}^{2}$, and the smallest has a planimetric area of $0.01 \mathrm{~km}^{2}$, with a mean of $0.54 \mathrm{~km}^{2}$ (based on the mean values from 21 regional studies). Cirque gradient and closure are rarely recorded, though based on the data summarised in Table 4, the mean (based on the mean values from three regional studies) axial gradient is $24^{\circ}$, and the mean 'average' gradient is $28^{\circ}$. Mean plan and profile closure are $125^{\circ}$ and $47^{\circ}$, respectively (Table 5).






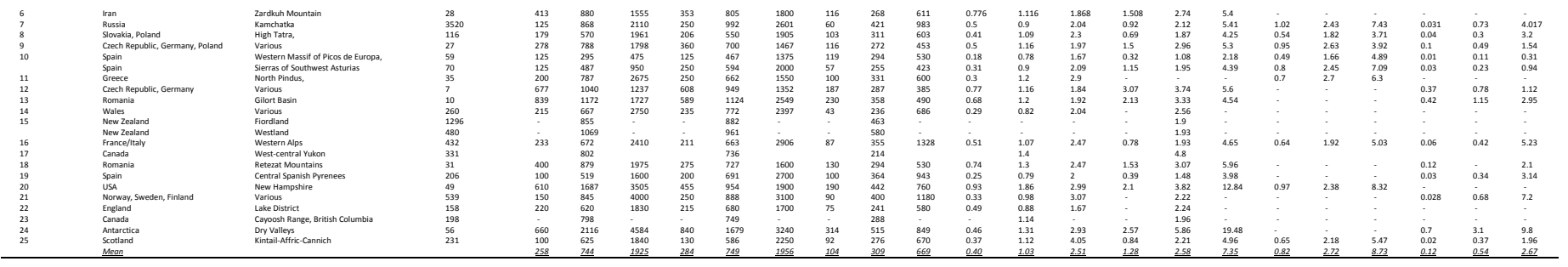

Table 5. Morphometric data from a globally distributed sample of cirques. Citations for each study are provided in the caption for Table 4.

\begin{tabular}{|c|c|c|c|c|c|c|c|c|c|c|}
\hline $\begin{array}{l}\text { Study } \\
\text { number }\end{array}$ & Country & Region & $\begin{array}{l}\text { Number } \\
\text { cirques }\end{array}$ & Cic. & Cic. & Cic. & $\begin{array}{l}\text { Axial gradient } \\
\left({ }^{\circ}\right)\end{array}$ & $\begin{array}{l}\text { 'Average' gradient } \\
\left({ }^{\circ}\right)\end{array}$ & $\begin{array}{l}\text { Plan closure } \\
\left({ }^{\circ}\right)\end{array}$ & $\begin{array}{l}\text { Profile closure } \\
\left({ }^{\circ}\right)\end{array}$ \\
\hline 3 & France & Eastern Pyrenees & 1071 & 1.03 & 1.13 & 1.52 & - & - & - & - \\
\hline 4 & Romania, Ukraine & Various & 631 & - & - & - & 24 & - & 137 & 43.3 \\
\hline 7 & Russia & Kamchatka & 3520 & 1.004 & 1.054 & 1.292 & - & - & - & - \\
\hline 8 & Slovakia and Poland & High Tatra, & 116 & 1.04 & 1.14 & 1.41 & - & 37 & - & - \\
\hline 9 & $\begin{array}{l}\text { Czech Republic, Germany, } \\
\text { Poland }\end{array}$ & Various & 27 & - & - & - & - & 26 & - & - \\
\hline 11 & Greece & North Pindus, & 35 & - & - & - & - & - & 138 & 35.4 \\
\hline 13 & Romania & Gilort Basin & 10 & 0.64 & 0.77 & 0.86 & - & 16.9 & - & - \\
\hline 14 & Wales & Various & 260 & - & - & - & - & - & 116 & 55.4 \\
\hline 16 & France/Italy & Western Alps & 432 & 1.02 & 1.1 & 1.68 & - & 31.8 & - & - \\
\hline 18 & Romania & Retezat Mountains & 31 & 0.33 & - & 1.51 & - & - & - & - \\
\hline 22 & England & Lake District & 158 & - & - & - & 22.81 & - & 120 & 55.86 \\
\hline 23 & Canada & $\begin{array}{l}\text { Cayoosh Range, British } \\
\text { Columbia }\end{array}$ & 198 & - & - & - & - & - & 134 & 55.3 \\
\hline 24 & Antarctica & Dry Valleys & 56 & 0.72 & 0.91 & 1 & - & - & - & - \\
\hline \multirow[t]{2}{*}{25} & Scotland & Kintail-Affric-Cannich & 231 & - & - & - & 25.9 & - & 103 & 34.5 \\
\hline & Mean & & & 0.83 & 1.02 & 1.32 & 24.2 & 27.9 & 124.7 & 46.6 \\
\hline
\end{tabular}



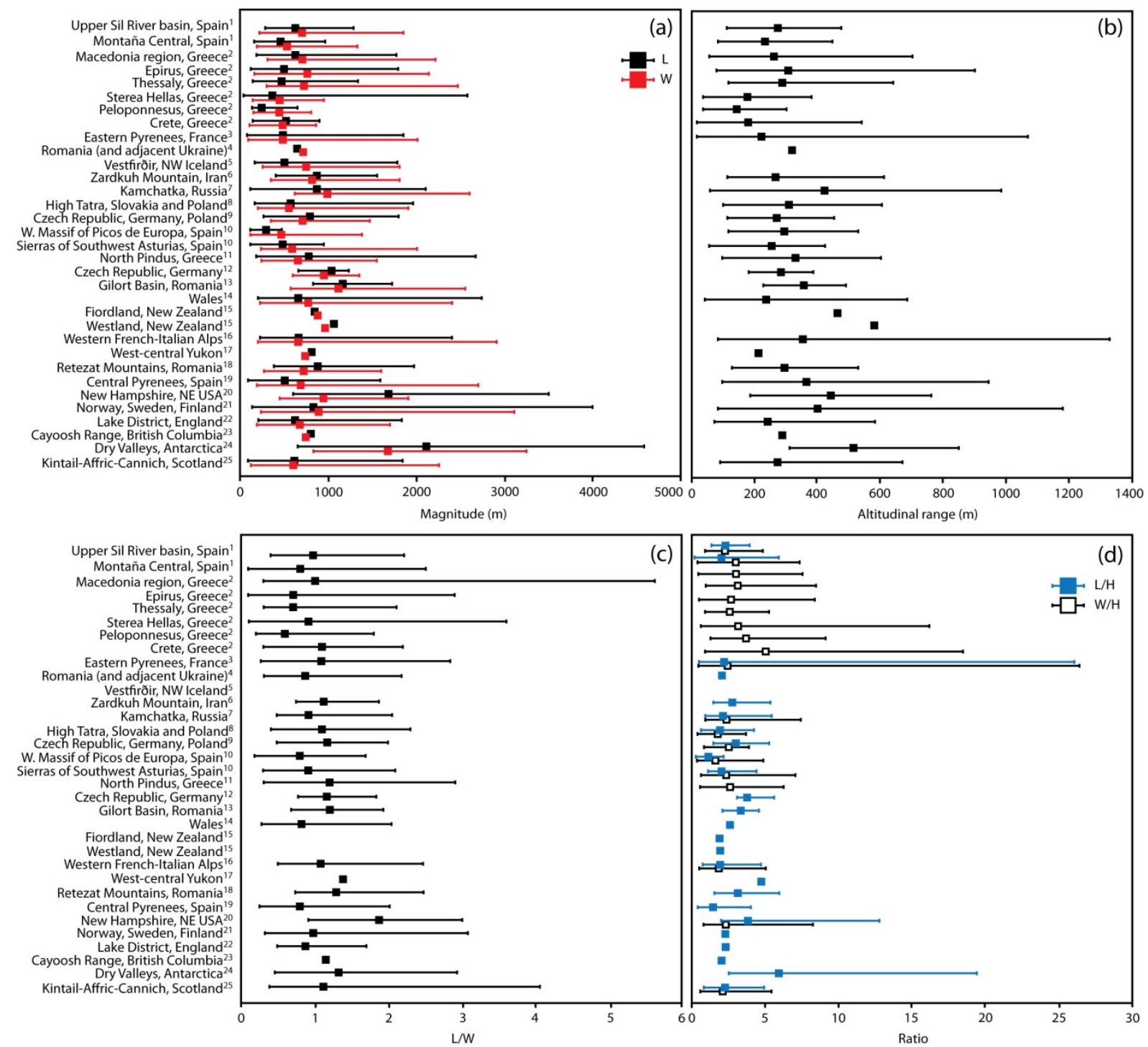

Fig. 17. A Global sample of cirque morphometrics (mean, maximum and minimum values are displayed here). (a) Cirque length and width. (b) Cirque altitudinal range (defined in various ways). (c) L/W, (d) L/H and/W W/H. Superscripts numbers refer to different studies (details are provided in Table 4).

Cirque longitudinal profiles are rarely measured, but where this does occur they are typically found to be concave and approximately half-parabolic (Graf, 1976), with the degree of concavity varying as a function of cirque overdeepening (Seif and Ebrahimi, 2014). Different functions have been used to provide a generalised description of cirque longitudinal profiles. One example comes from Haynes (1968) who used logarithmic curves of the following form (Eq. 1):

$y=k(1-x) e^{-x}$ (Eq. 1)

where $\mathrm{y}$ and $\mathrm{x}$ are vertical and horizontal coordinates, respectively ( $x$ is measured up valley from the lowest point behind the cirque threshold), and $k$ is a constant which describes the profile's concavity (Fig. 18).

Haynes (1968) investigated cirques in Scotland ( $n=67)$, and found $81 \%$ to have a $\mathrm{k}$ value between 0.5 (for cirques without steep headwalls but with shallow outward sloping floors) and 2.0 (for overdeepened cirques with steep headwalls). Thus, high $\mathrm{k}$ values typically correspond to well-developed, overdeepened cirques (Kř́ižek et al., 2012) (Fig. 18).

As an alternative to the logarithmic curves used by Haynes (1968), Graf (1976) suggested that cirque longitudinal profiles could be described by power law functions of the following form (Eq. 2) (initially used to describe cirques in the Rocky Mountains):

$y=a x^{b}$

where $y$ is altitude, $x$ is distance along the profile ( $x$ is measured up valley from the lowest point behind the cirque threshold), and both $\mathrm{a}$ and $\mathrm{b}$ are constants. In this instance, as cirque concavity increases, the $b$ value also increases.

Seif and Ebrahimi (2014) used this power law function to describe the longitudinal profiles of cirque-like features in the Zardkuh Mountains, Iran. The power function parameter b for each of these cirques was compared to the classification of Evans and Cox (1995) (outlined in section 2.1.), and b values were found to increase with the degree of cirque development. Specifically, 
grade 1 (classic) cirques ( $n=9$ ) were found to have a mean $b$ value of 2.07; grade 2 (Well-defined) cirques $(n=10)$ were found to have a mean value of 1.99 ; grade 3 (definite) cirques $(n=9)$ were found to have a mean value of 1.72 ; whilst grade 4 (poor) and 5 (marginal) cirque-like landforms $(n=30)$ were found to have a mean value of 1.39 .

(a)

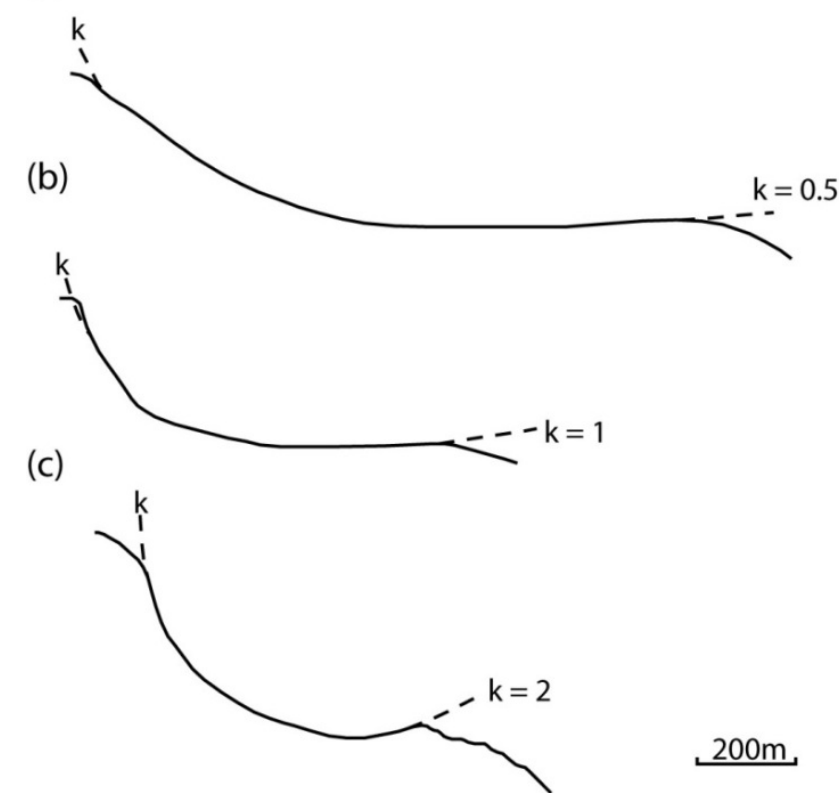

Fig. 18. Logarithmic curves (based on Eq. 1) fitted to the long profiles of three cirques in Scotland. (a) Calbach Coire, Cranstackie-Beinn Spionnaidh-Sutherland; (b) C. Duail, Foinne-bheinn-Sutherland; (c) C. na Poite, Applecross. Figure modified from Haynes (1968).

\subsubsection{Spatial trends in cirque morphometry}

Within individual cirque populations (e.g., within individual mountain ranges), cirque morphometry is often quite variable, though because of differences in definition and measurement, the extent of theses variations is sometimes difficult to fully assess. Despite this limitation, some general trends are evident. For example, it is apparent that inter-regional variations in cirque length and width are often comparable (i.e., where cirques are long, they also tend to be wide; and vice versa) (Fig. 19a). The largest cirques (in both length and width) are found in the Dry Valleys of Antarctica (Aniya and Welch, 1981), while the smallest are in mid-latitude areas, such as Greece (Bathrellos et al., 2014) and Spain (Ruiz-Fernández et al., 2009). Despite the interregional correspondence between cirque length and width, there are notable inter-regional variations in L/W (Fig. 17c). For example, the cirque population with the highest L/W is in New Hampshire, where, on average, cirques are 1.8 times greater in length than in width (Davis, 1999). By contrast, L/W is lowest in the mountain of Greece, where cirques are typically greater in width than length (Bathrellos et al., 2014). Inter-regional variations in cirque altitudinal range show some association with variations in length and width (i.e., cirques with large planimetric dimensions also tend to have large vertical dimensions) (Fig. 19b \& c). Generally, the cirque populations with the greatest altitudinal range are found in New Zealand (Richter, 2006), Kamchatka (Barr and Spagnolo, 2013), New Hampshire (Davis, 1999) and in the Dry Valleys of Antarctica (Aniya and Welch, 1981). By contrast, the shallowest cirques (i.e., those with the lowest altitudinal range) are found in the mountain of Greece (Bathrellos et al., 2014), and in the eastern Pyrenees (Delmas et al., 2014). Where both $\mathrm{L} / \mathrm{H}$ and $\mathrm{W} / \mathrm{H}$ are calculated, it is apparent that inter-regional trends in these measures are comparable (Fig. 17d). Mean L/H is greatest in the Dry Valleys Antarctica (reflecting the considerable length of cirques in this area) (Aniya and Welch, 1981), and is lowest in the Picos de Europa, Spain (Ruiz-Fernández et al., 2009). The cirque population with the highest mean W/H is in Crete (Bathrellos et al., 2014), and the lowest is in the Picos de Europa, Spain (Ruiz-Fernández et al., 2009).
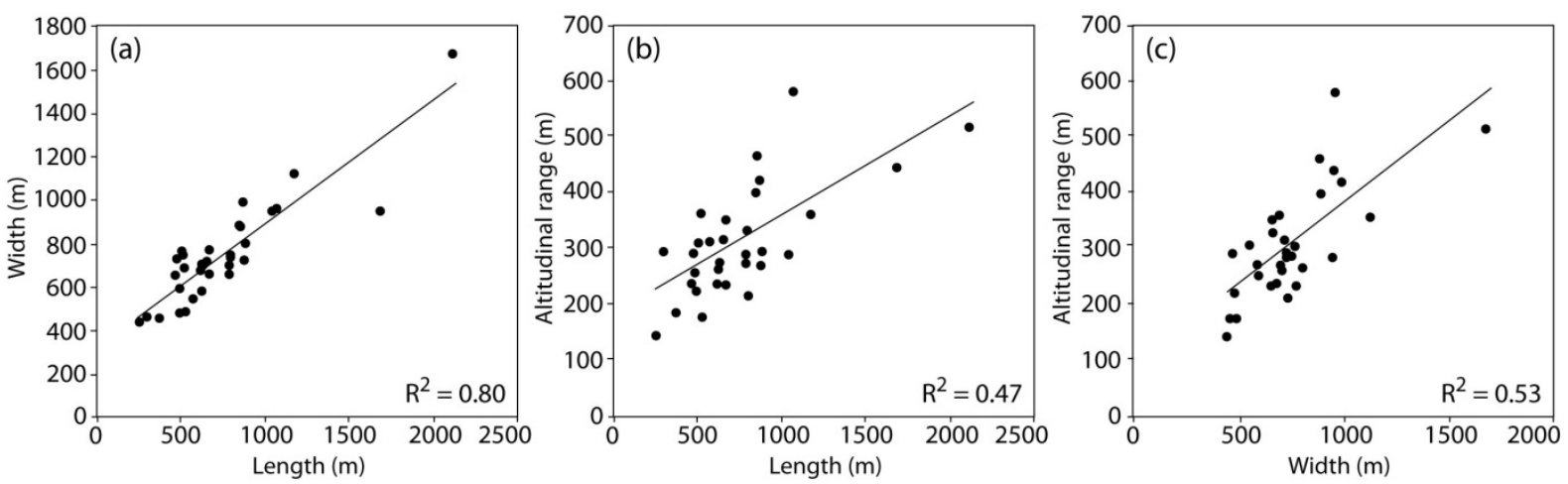

Fig. 19. Relationship between cirque morphometrics (population means) for different cirque populations globally (data from Table 4). (a) Width against length; (b) altitudinal range against length; and (c) altitudinal range against width. 


\subsubsection{Temporal trends in cirque morphometry}

Cirque length, width, and altitudinal range are all thought to increase as cirques grow (Fig. 6). Assuming the ergodic principle, that spatial variation can be substituted for variation with time, it might therefore be expected that as cirque size $\left({ }^{3} \mathrm{VLWH}\right)$ increases, length, width, and altitudinal range all also increase (as in Fig. 16). Evidence in support of this notion has been identified in many cirque populations globally (Evans and McClean, 1995; Federici and Spagnolo, 2004; Evans, 2006a). However, this growth has often been found to occur allometrically-with widening and lengthening outpacing deepening (Evans, 2010; Kř́žek and Mida, 2013; Mîndrescu and
Evans, 2014). This is reflected in Table 6, and Fig. 20, where power exponents for cirque length and width are consistently > 1.0, whilst power exponents for cirque altitudinal range are consistently < 1.0. Despite this trend, some have identified apparent evidence for comparatively isometric growth, where power exponents for cirque length, width and altitudinal range each approximate 1.0 (Fig. 20), suggesting that cirques grow almost equally in all dimensions. Examples include cirques in the Ben Ohau Range, New Zealand (Brook et al., 2006), on the Kamchatka Peninsula (Barr and Spagnolo, 2013), and in the Eastern Pyrenees (Delmas et al., 2015) (Fig. 20).
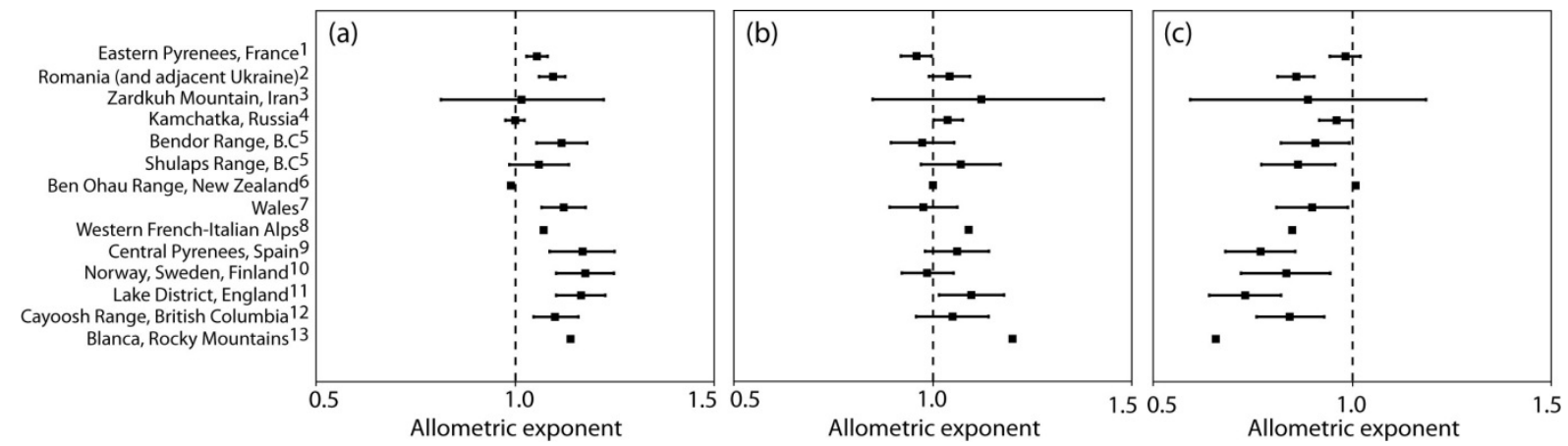

Fig. 20. Published power exponents (and $95 \%$ confidence intervals) for cirque (a) length, (b) width, and (c) altitudinal range. Image based on Delmas et al. (2015). Superscripts numbers refer to different studies (details are provided in Table 6).

Table 6. Power exponents for length, width and altitudinal range from a globally distributed sample of cirques (table based on Delmas et al., 2015). These data are presented in Fig. 20.

\begin{tabular}{|c|c|c|c|c|c|c|}
\hline $\begin{array}{l}\text { Study } \\
\text { number }\end{array}$ & Citation & Region & $\begin{array}{l}\text { Number } \\
\text { cirques }\end{array}$ & $\begin{array}{l}\text { Allometric exponent } \\
\text { (length) }\end{array}$ & $\begin{array}{l}\text { Allometric exponent } \\
\text { (width) }\end{array}$ & $\begin{array}{l}\text { Allometric exponent } \\
\text { (depth) }\end{array}$ \\
\hline 1 & Delmas et al (2015) & French Pyrenees & 1071 & 1.055 & 0.96 & 0.985 \\
\hline 2 & $\begin{array}{l}\text { Mîndrescu and Evans } \\
\text { (2014) }\end{array}$ & $\begin{array}{l}\text { Romania (and adjacent } \\
\text { Ukraine) }\end{array}$ & 631 & 1.095 & 1.043 & 0.861 \\
\hline 3 & $\begin{array}{l}\text { Seif and Ebrahimi } \\
\text { (2014) }\end{array}$ & Zardkuh Mountain, Iran & 28 & 1.016 & 1.122 & 0.891 \\
\hline 4 & $\begin{array}{l}\text { Barr and Spagnolo } \\
\text { (2013) }\end{array}$ & Kamchatka, Russia & 3520 & 1.0003 & 1.0378 & 0.9619 \\
\hline \multirow[t]{2}{*}{5} & Cited in Evans (2010) & $\begin{array}{l}\text { Bendor Range, British } \\
\text { Columbia }\end{array}$ & 222 & 1.117 & 0.975 & 0.908 \\
\hline & & $\begin{array}{l}\text { Shulaps Range, British } \\
\text { Columbia }\end{array}$ & 126 & 1.061 & 1.072 & 0.867 \\
\hline 6 & Brook et al (2006) & $\begin{array}{l}\text { Ben Ohau Range, New } \\
\text { Zealand }\end{array}$ & 94 & 0.99 & 1 & 1.01 \\
\hline 7 & Evans (2006a) & Wales & 260 & 1.122 & 0.977 & 0.901 \\
\hline 8 & $\begin{array}{l}\text { Federici and Spagnolo } \\
\text { (2004) }\end{array}$ & $\begin{array}{l}\text { Western French-Italian } \\
\text { Alps }\end{array}$ & 432 & 1.07 & 1.09 & 0.85 \\
\hline 9 & $\begin{array}{l}\text { García-Ruiz et al. } \\
\text { (2000) }\end{array}$ & Central Spanish Pyrenees & 206 & 1.17 & 1.06 & 0.769 \\
\hline 10 & Hassinen (1998) & Norway, Sweden, Finland & 539 & 1.177 & 0.988 & 0.835 \\
\hline 11 & Evans and Cox (1995) & Lake District, England & 158 & 1.166 & 1.099 & 0.736 \\
\hline 12 & $\begin{array}{l}\text { Evans and McClean } \\
\text { (1995) }\end{array}$ & $\begin{array}{l}\text { Cayoosh Range, British } \\
\text { Columbia }\end{array}$ & 198 & 1.102 & 1.05 & 0.847 \\
\hline 13 & Olyphant (1981) & Blanca, Rocky Mountains & 15 & 1.14 & 1.2 & 0.66 \\
\hline
\end{tabular}

\subsection{Cirque morphometry as a palaeoenvironmental indicator}

Variability in cirque morphometry has been used as a palaeoenvironmental indicator (e.g., Federici and Spagnolo, 2004; Mîndrescu et al., 2010). Specifically, morphometric information has been used to assess the nature and extent of cirque development, and to make subsequent links to palaeoclimate (i.e., the nature and extent of cirque development is deemed to have been, at least partly, controlled by palaeoclimate). This is discussed below, with reference to: (i) spatial variability in cirque morphometry; (ii) aspect-related variability in cirque morphometry; and (iii) temporal variability in cirque morphometry.

\subsubsection{Spatial variability in cirque morphometry}

Cirque dimensions are generally considered to reflect the intensity, duration and nature of glacial erosion and periglacial weathering. As a result, spatial variability in cirque morphometry has been used to infer spatial variability in these factors (e.g., Federici and Spagnolo, 2004; Steffanová and Mentlík, 2007; Delmas et al., 2015). In general, this approach is based on three key assumptions: (i) when glaciers extend slightly 
downvalley beyond cirque confines, cirque lengthening outpaces both widening and deepening, as the rotational movement of ice within the cirque is probably reduced or halted, thus limiting vertical incision; (ii) during periods of occupation by cirque-type glaciers, cirque development is roughly isometric, though widening slightly outpaces lengthening, which, in turn, slightly outpaces deepening; and (iii) when cirque development is dominated by periglacial weathering (e.g., when a cirque is glacier-free), widening outpaces lengthening and, particularly, deepening. Attempts to compare headwall vs. vertical erosion rates indicate that the two are similar (Table 1 ), thus providing at least some support for assumption (ii). Although there are no data available to test the other two assumptions, they seem reasonable and are more or less explicitly accepted by many researchers in this field (e.g., Damiani and Pannuzi, 1987; Federici and Spagnolo, 2004; Barr and Spagnolo, 2013; Seif and Ebrahimi, 2014). Based on these assumed relationships, some have used spatial variability in cirque length, width and altitudinal range to make inferences about the nature of cirque development. For example, in the Eastern Pyrenees, Delmas et al. (2015) found a notable difference between deeper cirques in the high sierras, and wider cirques in the lower outer sierras. Though the exact explanation for this trend is unclear, Delmas et al. (2015) consider the possibility that the development of wide cirques in the lower outer sierras reflects comparatively marginal glaciation in such areas. Such conditions mean that cirques would have been infrequently occupied by glaciers and their development may have been dominated by periglacial and other non-glacial processes (e.g., mass wasting). By contrast, in the high sierras, Delmas et al. (2015) consider that cirque deepening may have been promoted by extensive and prolonged glaciation (since the peaks rise high above the regional ELA), allowing significant subglacial erosion. Similarly, in the mountains of Greece, Bathrellos et al. (2014) found that cirque size is greater towards the north. This, they consider to reflect more frequent and longer lasting glacial conditions in northern areas, allowing more extensive and dynamic glaciation, and driving greater cirque erosion.

In some locations, the L/W ratio of cirques (or cirque populations) has been used to classify them according to the process/mechanism which has dominated their development (Damiani and Pannuzi, 1987; Federici and Spagnolo, 2004; Steffanová and Mentlík, 2007). For example, where L/W > 1, cirques are considered to have been mostly occupied and eroded by valley glaciers (extending beyond cirques); where $0.5<\mathrm{L} / \mathrm{W}<$ 1 , cirques are considered to have been mostly occupied and eroded by cirque-type glaciers; and where $\mathrm{L} / \mathrm{W}<0.5$, cirques are considered to have been highly eroded by post-glacial processes (Damiani and Pannuzi, 1987). Using this approach, Barr and Spagnolo (2013) consider 28\% of 3520 cirques on the Kamchatka Peninsula to have been mostly occupied and eroded by valley glaciers; $72 \%$ to have been mostly occupied and eroded by cirque-type glaciers; and very few $(n=5)$ to have been mostly shaped by periglacial processes (see section 2.2). By contrast, in the Zardkuh Mountains, Iran, Seif and Ebrahimi (2014) found all cirques to have L/W > 1, and therefore consider former glaciation to have been dominated by valley glaciers.

In some cases, cirques have been fed by incoming ice flowing over the headwall (e.g., in regions formerly occupied by plateau ice fields with outlet glaciers extending into surrounding valleys) (Brown et al., 2013; McDougall, 2013). In such cases, cirque form will undoubtedly have been modified by this external input of ice (e.g., Evans, 2010). For example, the Moelwyn and Siabod cirques of North Wales have been modified by the overriding Welsh ice cap (Evans, 2006a), and cirques in the Cairngorms have been modified by extensive ice sheet glaciation during the Last Glacial Maximum (Gordon, 2001). However, these modifications are only possible when the glacier ice near or in the cirque is warm-based. For example, in the Rassepautasjtjåkka massif of Northern Sweden, cirques have been entirely submerged by an ice sheet, but show little evidence of having been modified. This is presumed to reflect landscape preservation beneath minimally erosive, cold-based ice (Jansson et al., 1999).

\subsubsection{Aspect-related variability in cirque morphometry}

Aspect-related variations in cirque morphometry have been linked to past variations in local climate and the extent of former glaciation. For example, in the French Pyrenees, Delmas et al. $(2014,2015)$ found that NE-facing cirques tend to exhibit the greatest altitudinal range, whilst those facing SE tend to be the shallowest. As a result, they argued that glaciers on SE-facing slopes were perhaps short-lived, allowing periglacial widening (under marginal glacial conditions) to outpace subglacial deepening; whilst on NE-facing slopes glaciers were perhaps longer-lasting, allowing considerable subglacial cirque deepening. Similar results were also found in the Western Alps (Federici and Spagnolo, 2004). On the Kamchatka Peninsula, Barr and Spagnolo (2013) found SSE-facing cirques to be particularly large, and those on north-facing slopes to be particularly small. They use this evidence to argue that on SSE-facing slopes, former glaciers were particularly dynamic and erosive (with steep mass balance gradients), resulting in extensive erosion of both cirque floors and walls. They suggested that the smaller cirques on north-facing slopes may indicate that, despite being large and presumably long-lasting, glaciers were less dynamic or perhaps the conditions were so favourable that glaciers quickly grew beyond cirque confines.

These somewhat contrasting examples demonstrate that care should be taken when attempting to evaluate the importance of aspect on cirque morphometry, as this might lead to different patterns depending on other conditions beyond the simple effect of solar radiation or wind-direction.

\subsubsection{Temporal variability in cirque morphometry}

As noted in section 6.1.5., plotting cirque length, width and altitudinal range against overall cirque size (as in Fig. 16) has been used to assess whether cirques have developed isometrically or allometrically. This information has, in turn, been used to analyse the erosional history of cirques (e.g., Olyphant, 1981; Evans, 2006a, 2010). Specifically, imbalances between allometric coefficients for length, width and altitudinal range have been used to discriminate between cirque growth dominated by subglacial erosion, and cirque growth dominated by periglacial processes (notably freeze-thaw) (Delmas et al., 2015). For example, in instances where cirque widening and lengthening have appeared to outpace deepening (i.e., where growth has been allometric), it is assumed that periglacial processes and headwall recession have dominated over subglacial deepening, resulting in the formation of wide but shallow 'van' cirques (Delmas et al., 2015). Conversely, where cirque growth has been isometric (e.g., on the Kamchatka 
Peninsula), it is assumed that subglacial deepening has been able to keep pace with periglacial widening and headwall recession, resulting in the formation of deep 'armchair' cirques (Delmas et al., 2015). Given this, Barr and Spagnolo (2013) suggested that the apparent isometry of cirque development identified in some studies might indicate instances where former glaciers rarely extended beyond their cirques (as in Fig. 5a). The rationale behind this suggestion is that glaciers which are confined to their cirques may naturally result in isometric development, but that in many cases they are rarely afforded the time to do so, because glacier often grow beyond cirque confines, and focus subglacial erosion further down-valley (as in Fig. 5b). In such circumstances, cirques are likely to become occupied by cold-based, shallow, and minimally erosive glaciers which are frozen to their beds (Fig. $5 b)$. This limits cirque deepening, whilst cirque widening and headward retreat continue (Sanders et al., 2012, 2013). In the French Pyrenees, Delmas et al. (2015) found evidence for isometric cirque development in the elevated core of a Pleistocene icefield; and allometric cirque development in more peripheral areas. This they attribute to variations in former glaciation extent and intensity. Specifically, they suggested that apparent isometric development in interior regions may reflect intense subglacial erosion in response to long-lasting ice cover. By contrast, they suggested that the apparent evidence for allometric development in peripheral areas reflects lighter glaciation (as noted in section 6.3.1.) which has failed to erase the allometric signature of pre-Pleistocene topographic features such as shallow valley heads and 'etch-basins'. Notably, Delmas et al. (2015) suggested that the assumed allometry of cirque development (Evans, 2010; Kř́žek and Mida, 2013; Mîndrescu and Evans, 2014) may be wrong, and that geological structure and pre-glacial topographic inheritance play a key role in regulating cirque shape (i.e. there are both climatic and nonclimatic controls on cirque shape).

\section{Limitations with using cirques as palaeoenvironmental indicators}

As emphasised in sections 3-6, cirque attributes (distribution, aspect, altitude and morphometry) are often used as a source of information about past environments. However, the information derived is rarely unequivocal (i.e., variations in cirque attributes can be interpreted in a number of ways). There are also a number of confounding factors, which impact cirque distribution, altitude, aspect and morphometry, and limit our ability to accurately, robustly and systematically use cirques as palaeoenvironmental indicators. These factors are discussed below, with a focus on: (i) geology; (ii) the post-glacial modification of cirques; (iii) variations in cirque population size and age; and (iv) uncertainty about landform origin.

\subsection{The role of geology}

Though cirque distribution, aspect, altitude and morphometry are governed by palaeoenvironmental conditions, there are instances where bedrock lithology, structure and regional topography have clearly played a role in regulating these attributes, sometimes overshadowing other influences (Battey, 1960; White, 1970; Walder and Hallet, 1986). Such instances are discussed below.

\subsubsection{Geological controls on cirque distribution}

Cirque formation relies on glaciation, but is also limited to regions where lithology has 'allowed' bedrock to be eroded into armchair-shaped hollows. As a consequence, regional variations in bedrock erodibility can impact cirque distribution. For example, in the Romanian Carpathians, Mîndrescu and Evans (2014) found evidence for structural (bedding) control on the location of nested cirques. Specifically, they note that asymmetric uplift has resulted in bedding dip from north to south (but also from west to east) across the mountain range. As a consequence, northern slopes are characterised by short, steep bedding edges, with many steps. These steps, with weaker lithologies, provided sites for glacier formation during the Pleistocene. These conditions led to the preferential formation of cirques (particularly nested cirques) on northern and eastern slopes, with erosion facilitated by rockfalls, rock slope failures, and landslides. Mîndrescu and Evans (2014) suggested that the formation of nested cirques, in particular, is likely to be facilitated in such circumstances, where glaciers erode through bedrock with notable structural variations (or, at least, the detailed locations of nested cirques may be partly governed by structure), since these glaciers are likely to encounter numerous variations in erodibility that can be developed into tributary floors that lead to the formation of nested 'inner' cirques.

In addition to such structural controls, there are likely situations where accommodation space limits where cirque can form-perhaps explaining why, in some cases, cirques are only found on one side of a mountain range/divide (as in Fig. 7b). In such instances, even where climate allows symmetric glaciation, there may be no space for cirque development on climatically less favourable slopes (since glaciers on climatically favourable slopes may have eroded deeply into the mountain divide).This problem of limited accommodation space is highlighted by Evans (2006a) who notes that cirques are rarely isolated features, but can coalesce, limiting further enlargement despite ongoing erosion. Similarly, the fact that topography can sometimes limit cirque development is noted in section 5.3.3., since some peaks are too steep to allow the accumulation of glacial ice, or the ice that accumulates is too thin to allow cirque basins to be eroded (Ward et al., 2012; Godard et al., 2014). Such factors (governing cirque distribution) clearly mean that the absence of cirques in a particular region cannot be used unequivocally as evidence that Pleistocene (or earlier) glaciers have been absent.

\subsubsection{Geological controls on cirque aspect}

In some regions, there is evidence for structural control on cirque aspect (Gordon, 2001; Evans, 2006b). For example, Bathrellos et al. (2014) found cirque aspect in the mountains of Greece to be partly attributable to the orientation of the region's mountain chains (though climate plays the significant role). Similarly in SE Kamchatka, there is some evidence that cirque aspect is influenced by the orientation of the region's mountain chains (Barr and Spagnolo, 2013). However, despite such examples, Evans (2006b) suggested that the role of structure in regulating glacier (and by extension cirque) aspects is limited, and such influences are likely to become less apparent when large (structurally varied) areas and/or large cirque populations are considered (see section 7.3.). This view is supported by data from Kamchatka, where structural control on cirque aspect only becomes apparent when the peninsula's large cirque population $(n=3520)$ is sub divided by mountain chain (Barr and Spagnolo, 2013). 


\subsubsection{Geological controls on cirque morphometry}

Variations in lithology (i.e., bedrock erodibility), structure and topography are known to have an impact on cirque morphometry (Haynes, 1968; Addison, 1981), though unambiguously identifying such controls is often difficult (Evans, 1994, 2006a). Some (e.g., Haynes, 1968; Walder and Hallet, 1986) consider lithology and structure to be key controls, whilst others have found relief to be more important (e.g., Embleton and Hamann, 1988). In the French Pyrenees, Delmas et al. (2015) found that among crystalline rocks (granite, gneiss, migmatite), cirque form is predominantly determined by climate, but among schist outcrops, bedrock characteristics (e.g., structure) are the key controls. Evans (2006a,b) and Mîndrescu and Evans (2014), found some evidence that, in Wales and Romania respectively, cirque altitudinal range is most closely related to geology, whilst length and width show little (but some) relation. Mîndrescu and Evans (2014), also note that maximum and overall headwall gradient vary according to lithology, as does plan closure and cirque grade (see section 2.1.). In the Carneddau (North Wales), Bennett (1990) found deep cirques to coincide with cirque floors on weaker strata. However, in this example, geology varies in conjunction with relief, and differentiating between these possible controls is difficult (Evans, 2006a). In northern Greece, Hughes et al. (2007) found cirques on limestone to have twice the amplitude of those on ophiolites (ultrabasic rocks) and to have significantly greater length and plan closure. By contrast, in Crete, where karstified carbonate rocks (i.e., limestones) dominate cirque lithology, Bathrellos et al. (2014) suggested that high $\mathrm{W} / \mathrm{H}$ values may indicate that a significant amount of snowmelt (and presumably glacial meltwater) infiltrated into the bedrock, thereby limiting subglacial deepening. On Vestfirðir, NW Iceland, Principato and Lee (2014) argued that the tendency for cirques to be wider, but not as long, as in other alpine regions globally (based on comparison with a global dataset), likely reflects bedrock structure and topography. Specifically, the Upper Tertiary flood basalts with thin interbedded horizontal sedimentary layers are probably easier to erode in the horizontal direction than in the vertical direction because of lithological weaknesses. Finally, in North Wales, Bennett (1990) found evidence that cirques tend to be elongated along-strike.

\subsection{Post-glacial modification of cirques}

The post-glacial modification of cirques can have an impact on their (apparent) distribution, altitude and morphometry. The factors considered here are: (i) post-glacial uplift, and (ii) post-glacial weathering, erosion and infilling.

\subsubsection{Post-glacial uplift}

Post-glacial tectonics (uplift and subsidence) can lead to the displacement of cirques from the altitudes at which they are formed. This typically involves post-glacial uplift (including isostatic rebound), and its significance varies from region to region and depends not only on the rate of uplift but also on the time since cirque formation. For example, in the mountains of Greece, Bathrellos et al (2014) found some evidence that rapid uplift has had an impact on cirque floor altitudes. However, the impact that uplift might have had on cirque altitudes is often very difficult to unambiguously identify. Even in instances where postglacial uplift is assumed to have had an impact on cirque altitudes (and such cases are very rare), establishing precise values and spatially variability in these values may be impossible (often because of difficulties with establishing a chronology for cirques-see section 8.3), and, as a consequence, cirque altitudes are rarely corrected for uplift (Bathrellos et al., 2014)

\subsubsection{Post-glacial weathering, erosion and infilling}

Following deglaciation, cirques continue to be modified by weathering, erosion and infilling (Hättestrand et al., 2008). Such processes have some impact on cirque identifiability (i.e., cirques become degraded) (Nelson and Jackson, 2003), and also impacts their morphometry. For example, cirque length and width are likely to be modified by mass movements (e.g., slumps and slides) which remove material from their headwalls and margins, and allow talus to accumulate on cirque floors (Shakesby and Matthews, 1996; Gordon, 2001). As sediment/debris accumulates in cirques following deglaciation, their altitudinal range and gradient are likely to be reduced. Infilling debris may include: (i) weathered and eroded material from cirque slopes (Evans, 2006a); (ii) material deposited by a retreating cirque glacier (including marginal and hummocky moraines) (Evans, 1977); (iii) material originating from a former rock glacier; (vi) material (i.e., cirque infill) derived from a continental ice sheet lobe flowing up-valley and into cirques (Hättestrand et al., 2008). In addition (as noted in the introduction to this paper), a number of cirques contain lakes (tarns) and/or bogs, the depth of which is rarely known. In many cases, the surface of a lake or bogs is considered to reflect the cirque floor altitude (e.g., Evans and Cox, 1995), though, in reality, this water and/or sediment may have considerable depth (e.g., Blea Water which occupies a cirque in the English Lake District is $63 \mathrm{~m}$ deep). Hättestrand et al (2008) found cirque infills to be up to $50 \mathrm{~m}$ deep, though robust estimates of the thickness/volume of sediment contained within cirques are very few.

\subsection{Variations in cirque population size and age}

Patterns arising from small populations or, perhaps more importantly, the masking of patterns in large and heterogeneous populations, can be a problem when attempting to derive palaeoenvironmental information from cirques (see section 7.1.2.). For example, some have suggested that the apparent absence of an allometric record of cirque development in some locations may be a result of the fact that a cirque population is particularly large, and/or that the region analysed is large and varies considerably in terms of its structure and lithology (Evans, 1994; Sauchyn et al., 1998; Hughes et al., 2007). For example, in the eastern Pyrenees, Delmas et al. (2014) found that when the total cirque population $(n=1071)$ is split into subpopulations (defined on the basis of massif location, cirque aspect, and lithology), there is more variation (i.e., patterns emerge) in allometric coefficients for length, width and altitudinal range. This, they have suggested, indicates that large cirque populations conceal a wealth of quantitative and spatial information. Thus, analysing smaller populations, or focusing on small areas, may simplify the process of inferring palaeoclimate from cirques. However, the statistical significance of results should be taken into consideration, since speculative inferences based on differences between small populations can be misleading.

A further limitation of dealing with large cirque populations, or large areas, is that when a group of cirques are 
being used as palaeoenvironmental indicators, it is often assumed that their formation has been simultaneous (i.e., formation has not been time-transgressive) (Evans, 2006b). This assumption is more likely to hold in small regions (Evans, 1999, 2006b), as, in many cases, large cirque populations likely reflect several sub-groups, each relating to different periods and palaeoclimates. For example, in the western Cairngorms, Sugden (1969) identified three discrete cirque generations (distinguished on the basis of their size and position). Analysing cirque populations which contain multiple generations (sub samples) introduces complexity when trying to make clear links to palaeoclimate. For example, differences in cirque aspect within a single large population might reflect climatic differences between, say two, different periods of glaciation. This is apparent in east-central Alaska, where two distinct cirque populations of different ages are distinguished by Péwé et al., (1967), with the younger, fresher cirques appearing to have a different resultant vector than less fresh examples (in this case hinting at a different wind regime for the two glaciations involved) (Table 2).

Thus, multiple cirque populations clearly create difficulties when trying to relate cirque attributes to a single palaeoenvironment. One key to resolving this issue would be to accurately constrain the age of each cirque, however, establishing the timing of cirque initiation and development is notoriously difficult (Turnbull and Davies, 2006). In many areas, this is because cirques have likely developed (i.e., been occupied and eroded) during multiple glacial cycles (e.g., Rudberg, 1992; Gordon, 2001). However, this may not be true everywhere, and there are regions where cirques may have formed during a single phase of glacier occupation (Chen et al., 2014), or where cirques pre-date the Quaternary (sometimes preserved beneath coldbased ice)-for example in Antarctica (Holmlund and Näslund, 1994; Haynes, 1995) and Sweden (Jansson et al., 1999). Ultimately, our understanding of cirque chronology is limited, and though we might be able to chronologically constrain cirque de-activation (e.g., through surface exposure dating), the dating of cirque initiation, or ascertaining periods of repeated cirque occupation remains very difficult (see section 8.3.).

\subsection{Uncertainty about landform origin}

When using cirques as palaeoenvironmental indicators, the assumption is made that the features in question are of glacial origin. However, the specific origin of 'glacial' cirques has been disputed (Evans 2006a; Turnbull and Davies, 2006), and in some instances, features mapped (and analysed) as cirques may in fact be of non-glacial origin (Chen et al., 2014; Seif and Ebrahimi, 2014). This clearly has important implications for the use of cirques as palaeoenvironmental indicators, and is discussed below.

\subsubsection{A disputed origin for glacial cirques}

As noted in section 2.2., it is widely accepted that glacial cirques form through the enlargement (by glacial and periglacial processes) of pre-existing mountainside hollows of various origins (Haynes, 1998; Jarman, 2002; Evans 2006a). The use of glacial cirques as palaeoenvironmental (particularly palaeoclimatic) indicators essentially assumes that irrespective of hollow origin, the distribution and dimensions of cirques is determined by climatic controls on the glacial and periglacial processes that come to shape them (i.e., the initial depressions are typically small, but are enlarged to form cirques). However, this assumption may not always hold since Turnbull and Davies (2006) argued that glacial erosion is insufficient to account for the development of large cirques, and that such cirques likely reflect regions where glaciers have come to occupy large and preexisting cirque-like hollows formed by deep seated rock slope failures (Davies et al., 2013; Jarman et al., 2014). In such instances, the validity of using cirque distribution or morphometry as palaeoenvironmental indicators is questionable.

\subsubsection{Incorrect landform identification}

A number of processes can result in cirque-like forms which might be incorrectly classified as glacial cirques (some of these may be the initial topographic depressions from which cirques are assumed to develop). Cirque-like forms which might be incorrectly identified as glacial cirques include: nivation hollows; mass movement scars (derived from rockfalls, landslides etc.); karstic depressions; or volcanic craters (Davies et al., 2013). Cirque-like depressions relating to nivation are a particular problem, since they resemble glacial cirques in many ways (Evans and Cox, 1974; Seif and Ebrahimi, 2014). The best way to distinguish between cirques and cirque-like forms is to conduct detailed analysis (including field-based investigations), but in some remote areas (certainly on Mars), and in the case of some very large cirque populations, this is simply not possible. As a result, some have attempted to use remote sensing and GIS techniques to differentiate between these different forms. For example, Chen et al. (2014) distinguish between glacial cirques and 'firn basins' in the Daweishan Mountain area of eastern China using what they refer to as a 'flat index' (i.e, L/2H) and the $\mathrm{L} / \mathrm{W}$ ratio. They compare $\mathrm{L} / \mathrm{W}$ ratios to those of Federici and Spagnolo (2004), to ascertain what constitute 'typical' values for glacial cirques. They judge flat index values based on Derbyshire and Evans (1976), stating that a typical value for a glacial cirque is between 1.7 and 5.0, whilst firn basins have values of 4.25 to 11.0. By contrast, Seif and Ebrahimi (2014) used longitudinal profiles when attempting to distinguish between cirques and cirque-like (non glacial) forms (i.e., b coefficients are analysed) (see section 6.2.1.).

\section{Future research directions}

The adoption of remote sensing and GIS techniques over recent years has led to considerable developments in the use of cirques as palaeoenvironmental indicators. However, beyond continued mapping and analysis to produce global, or near global, datasets of cirques, there are a number of other areas that require future attention. Some of these are briefly discussed in this section.

\subsection{Better understanding of cirque evolution}

Assessing the palaeoenvironmental significance of cirque distribution, aspect, altitude and morphometry relies on understanding the history of a cirque. Specifically there is a need to establish the rate at which cirques are eroded, and establish when active erosion actually occurs. Some of the questions which need addressing include the following: (i) are cirques actively eroded by valley glaciers and larger ice masses, or is erosion limited solely to periods when cirques are occupied by small glaciers? (ii) If large ice masses can erode cirques, how does this erosion differ (in terms of style and rate) from erosion by a cirque glacier? (iii) If large glaciers fail to actively erode cirques (i.e., if the cirque becomes occupied by ice that is cold-based and/or has 
a shallow surface gradient), at what point does a glacier become too large to erode a cirque? Many such questions might be answered by numerically modelling cirque initiation and growth during full glacial cycles (or perhaps multiple glacial cycles). Some numerical landscape evolution models produce cirques (e.g., Egholm et al., 2009), but such models are rarely (if ever) used to look at cirques specifically, and verification of these models relies on robust empirical data about cirque chronology and erosion rates (information which is currently lacking, see 8.2 and 8.3 ).

\subsection{Estimating cirque erosion rates}

Establishing the rate at which cirques are eroded is key to understanding interactions between climate, glaciers and topography. Specifically, a first order test for the buzzsaw hypothesis (i.e., the idea that glacial erosion acts to limit mountain topography at a near global sale) (see section 5.3.3) would be to quantify cirque erosion rates, and compare these values to rates of mountain uplift. However, as noted in section 2.2.1., published erosion rates for cirques are limited (Table 1) partly because of difficulties with obtaining estimates from modern glaciers (Sanders et al., 2013), but also because of difficulties with establishing a chronology for cirque formation (see section 8.3.). Thus, obtaining robust estimates of cirque erosion rates depends partly on further direct measurement of erosion by modern cirque glaciers, but also on establishing a chronology for cirques (i.e., dating their initiation, growth, deactivation, re-activation, etc.).

\subsection{Establishing a chronology for cirque development}

Palaeoenvironmental data derived from cirques would be more useful if assigned to a particular time period. In addition, ascertaining when cirques formed is particularly important for estimating erosion rates (as noted in section 8.2.), and for assessing the impact of tectonic uplift on cirque altitudes. The last glaciation is considered to have had a major impact on the development of cirques especially in marginal regions where, throughout the millennia of glaciation, only cirque glaciers formed and thrived (i.e. no valley glaciers developed or lasted for long). For example, this is considered to be the case in some mountainous areas across the Mediterranean, where cirque development is typically associated to the last glacial cycle (e.g. Hughes et al., 2006). However, in most other regions, glaciers were actively eroding cirques only during the onset and termination of a glacial cycle, or even during interglacials (Kleman and Stroeven, 1997). In these cases, the full development of cirques is considered the product of multiple glacial (or interglacial) cycles, of unknown number (Rudberg, 1992; Gordon, 2001). Thus the timing of cirque initiation and development remains extremely difficult to constrain (Turnbull and Davies, 2006). Fortunately, recent developments in geochronometric dating (particularly surface exposure dating) potentially allow at least the timing of cirque de-activation to be constrained, by estimating the length of time glacially abraded bedrock within a cirque has been exposed to the atmosphere. However, such methods have yet to be applied to the analysis of cirque development specifically, and establishing a chronology for cirques is further hampered by the fact that there are currently no robust ways of dating cirque initiation, or establishing whether a cirque has undergone repeated phases of glacial occupation.
8.4. Developing (semi)automated techniques for cirque identification and mapping

As noted in section 7.4.2., difficulties sometimes arise when cirque-like forms are incorrectly classified as glacial cirques. In an attempt to alleviate this problem, automated methods for cirque identification and classification (i.e., separating cirques into their different components, such as cirque crest, headwall, lake/tarn) have been developed (e.g., Eisank et al., 2010; Ardelean et al., 2011. 2013; Seijmonsbergen et al., 2014). Such techniques rely on knowledge of 'typical' cirque characteristics (based on morphometric analyses), and use this information to guide automated techniques (using DEMs) (e.g., Ardelean et al., 2011, 2013). These methods have the potential to allow rapid cirque mapping over large areas, in an objective and systematic way. However they have some key limitations (e.g., the lower boundaries of cirques are often difficult to identify) (Ardelean et al., 2011, 2013; Seijmonsbergen et al., 2014), and, as a result, are not widely applied. There is likely to be further progress in developing such techniques over future years, though whether they will be widely used to complement, or replace, manual mapping techniques remains to be seen.

\section{Summary}

The use of glacial cirques as palaeoenvironmental indicators has a strong heritage, and has experienced a recent resurgence. This resurgence is partly due to the development of remote sensing and GIS techniques, but also reflects the growing recognition that cirques are key to understanding many interactions between glaciers, climate, geology and topography. This paper provides a critical assessment of cirques as indicators of past environments, and focuses on information that can potentially be derived from their distribution, aspect, altitude, and morphometry. This palaeoenvironmental information can be summarised in the following points (also detailed in Table 7):

1. The presence of cirques in a given location tells us that topoclimatic conditions once allowed the build of perennial snow and ice to a thickness that enabled metamorphosis and the formation of glacial ice. The glaciers that resulted were steep enough to undergo rotational flow (i.e., $\alpha>7^{\circ}$ ) (Lewis, 1949, 1960), and were dynamic and/or sufficiently long-lasting (perhaps reflecting repeated phases of glacial occupation) to excavate their underlying bedrock. If these glaciers were dynamic (with high accumulation and ablation), cirques may have been eroded in a few hundred thousand years (during one or more phases of glaciation), but if glaciers were cold-based and minimally erosive (e.g., under cryo-arid conditions), cirque erosion may have taken a million years or more (during repeated phases of glaciation).

2. The absence of cirques in a particular location can indicate that topoclimatic conditions have not been conducive to the development of glaciers (perhaps throughout the Quaternary). However, cirque absence isn't necessarily a definitive indicator of the former absence of glaciers. For example, past glaciers may have been minimally erosive, or may have occupied notably resistant bedrock-meaning that they were unable to generate cirques that are identifiable in the modern landscape. Despite such limitations, the absence of 
cirques in a location where they might be 'expected' (e.g., in proximity to other cirque-occupied mountains of similar altitude, lithology and modern climate) might provide information about past environmental conditions. For example the absence of cirques in such a locality might reflect palaeoclimatic gradients which are no longer present (e.g., during former periods of glaciation palaeoprecipitation patterns may have differed significantly from present).

3. Where cirque aspect (orientation) shows a strong poleward bias (as reflected by strong aspect asymmetry); a notable tendency towards the NNE or SSE directions (in the Northern and Southern Hemispheres, respectively); or where aspect-related variations in cirque floor altitude are notable, this can indicate that former glaciers developed (and eroded cirques) under comparatively dry, and therefore cloud-free ablation season conditions, which allowed aspect-related variations in direct solar radiation to be maximised. Equally, these attributes might indicate that cirque development occurred under marginal glacial conditions (perhaps driven by aridity), when glaciers were able to develop, and erode cirques only on climatically favourable slopes, and/or where glaciers on climatically unfavourable slopes were only able to develop at comparatively high altitudes.

4. Where cirque aspect shows a tendency towards nonpoleward directions, this can indicate dominant palaeo wind directions. For example, there is a tendency for many mid-latitude cirques to face eastward, as a result of former glacier growth in the lee of westerly winds which dominate at these latitudes. In such circumstances, this likely indicates that local sheltering, possibly combined with the supply of redistributed snow and ice from surrounding slopes, allowed numerous glaciers to form even on climatically unfavourable (or less favourable) slopes. Such glaciers may have experienced considerable mass loss through melting (in response to direct solar radiation), and, if replenished by snowfall and redistributed snow and ice, may have been particularly dynamic (i.e., with high mass-flux). By contrast, where cirque aspects appear not to reflect palaeo winds, but have strong poleward tendencies, this might indicate that palaeo winds were rarely strong, or consistent, enough to result in the preferential formation of glaciers on leeward slopes, and that the survival of former glaciers was a result of restricted ablation (on shaded, pole-facing, slopes). Such glaciers may have persisted even with minimal accumulation, and are therefore unlikely to have been particularly dynamic.

5. In regions where there are notable spatial variations in cirque floor altitudes, this might reflect latitudinal variations in palaeotemperatures, or, more likely, spatial variability in precipitation (particularly snowfall) during former periods of glaciation. As such, cirque floor altitudes can provide information about palaeoprecipitation gradients (and wind directions) during former periods of glaciation.

6. Cirque floor altitudes are often considered a proxy for ELAs during former periods of cirque type glaciation.
This assumption allows comparison with modern ELA/snowline trends, and can potentially be used to obtain quantitative palaeoclimate data (though the time period represented may be unknown).

7. Where cirque floor altitudes and peak altitudes are found to co-vary across a region (i.e., in regions characterised by the signature of the 'glacial buzzsaw'), this might reflect the former presence of dynamic and/or long-lasting glaciers, which have eroded peaks and intervening ridges from all sides (i.e., where former glaciation has been comparatively symmetrical, allowing glaciers to develop even on climatically unfavourable slopes). Conversely, where cirque floor altitudes and peak altitudes do not clearly co-vary (e.g., in the N. Sredinny Mountains-Barr and Spagnolo, 2014), this might indicate that glaciation has been marginal (with glaciers only able to develop, and erode cirques, on climatically favourable slopes), short lived, and perhaps characterised by cold-based (minimallyerosive) ice; or that former glaciers grew quickly, and then persisted, beyond cirque confines, meaning that the zone of maximum subglacial erosion was focused further downvalley, and for the most part of the glaciation(s) cirques themselves were occupied by coldbased, minimally erosive ice (leading to an overall increase in topographic relief). Alternatively, the absence of a clear buzzsaw signature might indicate that a region has undergone considerable post-glaciation uplift (able to outpace denudation via the glacial buzzsaw) or that considerable time has elapsed since deglaciation (Barr and Spagnolo, 2014).

8. Cirque dimensions are generally considered to reflect the intensity, duration and nature of glacial erosion and periglacial weathering. As a result, variability in cirque morphometry has been used to analyse the processes and mechanisms which have dominated cirque development. Specifically:

- Where cirques are particularly large, this might indicate that former cirque glaciers were dynamic and/or long-lasting-allowing considerable erosion to occur.

- The prevalence of comparatively shallow, but wide cirques might indicate that cirque development was dominated by periglacial (partly post-glacial) processes-allowing lateral expansion to outpace subglacial deepening and headwall erosion. Such conditions might indicate marginal and/or short-lived glaciation, with cirques infrequently occupied by glaciers.

- The prevalence of comparatively long, but shallow cirques might indicate that former valley glaciers dominated cirque development-allowing some headward erosion, but limiting subglacial deepening (as the zone of maximum subglacial erosion was located beyond cirque confines).

- The prevalence of comparatively symmetrical cirques, and/or where there is evidence for isometric cirque development, might indicate that small glaciers have dominated cirque development-allowing subglacial deepening, 
headwall erosion, and the subaerial (periglacial) widening to occur at comparable

rates.

Given the points listed above (and summarised in Table 7), it is apparent that, despite complex controls on their initiation and development, cirques provide a valuable and varied source of palaeoenvironmental information (if used judiciously), particularly in remote and inaccessible regions where other palaeoenvironmental proxies are limited or lacking.

Table 7. Summary of palaeoenvironmental information that can be derived from cirques

\begin{tabular}{|c|c|c|c|}
\hline Attribute & Factor & Section & Potential palaeoenvironmental inferences \\
\hline $\begin{array}{l}\text { Cirque } \\
\text { distribution }\end{array}$ & Cirque presence & 3.3. & $\begin{array}{l}\text { - Topoclimatic conditions once allowed the build of perennial snow and } \\
\text { ice to a thickness that enabled metamorphosis and the formation of } \\
\text { glacial ice. The glaciers that resulted were steep enough to undergo } \\
\text { rotational flow (i.e., } \alpha>7^{\circ} \text { ), and were dynamic and/or sufficiently } \\
\text { long-lasting to excavate their underlying bedrock. }\end{array}$ \\
\hline
\end{tabular}

Cirque absence

Cirque aspect

Aspect shows a strong poleward bias; aspect

4.3.1. shows a notable tendency towards the NNE or SSE directions (in the Northern and Southern Hemispheres, respectively); and/or Aspectrelated variations in cirque floor altitude are notable

Aspect shows a tendency towards nonpoleward directions altitudes

Cirque floor altitudes and peak altitudes are found to co-vary across a region

Cirque floor altitudes and peak altitudes don't clearly co-vary across a region

$\begin{array}{lll}\text { Cirque } & \text { Large cirques } & 6.3 .1 . \\ \text { morphometry } & & 6.3 .2 . \\ & \text { Shallow, but wide cirques } & 6.3 .1 . \\ & & 6.3 .2 .\end{array}$

prevalence of comparatively long, but shallow cirques
5.3.3.
- Topoclimatic conditions have not been conducive to the development of glaciers, or past glaciers were minimally erosive (at least at the valley heads), and/or the bedrock is notably resistant-meaning that glaciers were unable to generate cirques that are identifiable in the modern landscape.

- $\quad$ Cirque absence in a locations where they might be 'expected' might indicate palaeoclimatic gradients (exerting a control on former glacier distribution) which are no longer present.

- $\quad$ Former glaciers developed (and eroded cirques) under comparatively dry, and therefore cloud-free ablation season conditions, which allowed aspect-related variations in direct solar radiation to be maximised. The survival of these glaciers may have been promoted by restricted ablation (on shaded, pole-facing, slopes), allowing glaciers to persist even with minimal accumulation

- $\quad$ Cirque development occurred under marginal glacial conditions (perhaps driven by aridity), when glaciers were only able to develop, and erode cirques, on climatically favourable slopes, and/or where glaciers on climatically unfavourable slopes were only able to develop at comparatively high altitudes.

- $\quad$ Palaeo winds may not have been strong, or consistent enough to result in the preferential formation of glaciers on leeward slopes, or prevailing winds were blowing in a poleward direction.

- $\quad$ Cirque aspects indicate dominant palaeo wind directions (i.e., glacier growth, and cirque formation, may have occurred in the lee of dominant winds).

- $\quad$ Former glaciers may have experienced considerable mass loss through melting (in response to direct solar radiation on climatically lessfavourable slopes), and, if replenished by snowfall and redistributed snow and ice, may have been particularly dynamic (i.e., with high mass-flux).

- Reflect variations in ELA during former periods of glaciation. Thus, cirque floor altitudes provide information about dominant moisture sources, wind directions, and precipitation gradients during former periods of glaciation.
- Reflect the former presence of dynamic and/or long-lasting glaciers, which have eroded peaks and intervening ridges from all sides.

- Glaciation has been marginal (with glaciers only able to develop, and erode cirque, on climatically favourable slopes), short lived, perhaps characterised by cold-based ice; or former glaciers may have been extensive, meaning that the zone of maximum subglacial erosion was focused beyond cirque confines-leading to an overall increase in topographic relief.

- $\quad$ The region may have undergone considerable post-glaciation uplift (able to outpace denudation) or that considerable time has elapsed since deglaciation.

- $\quad$ Former glaciers were dynamic, long-lasting and/or occupied readily erodible bedrock

- Cirque development has been dominated by periglacial processesallowing lateral expansion to outpace subglacial deepening and headwall erosion. Such conditions might indicate marginal and/or short-lived glaciation, with cirques infrequently occupied by glaciers.

- $\quad$ Former valley glaciers have dominated cirque development-allowing some headward erosion, but limiting subglacial deepening (as the zone 
Prevalence of comparatively symmetrical cirques (i.e., equal in $\mathrm{L}, \mathrm{W}$ and $\mathrm{H}$ ), and/or evidence for isometric cirque development

\section{Acknowledgements}

We thank the reviewers, Ian Evans and Simon Carr, and particularly the editor lan Candy, for their extremely helpful corrections, comments and suggestions.

\section{References}

Abele, G., 1964: Die Fernpasstalung und ihre morphologischen Probleme. Tübinger Geogr. Studien, Ht 12.

Addison, K., 1981. The contribution of discontinuous rock-mass failure to glacial erosion. Ann. Glaciol. 2, 3-10.

Anders, A.M., Mitchell, S.G., Tomkin, J.H., 2010. Cirques, peaks, and precipitation patterns in the Swiss Alps: connections among climate, glacial erosion, and topography. Geology 38 (3), 239-242.

Anderson, L.W., 1978. Cirque glacier erosion rates and characteristics of Neoglacial tills, Pangnirtung Fiord area, Baffin Island, NWT, Canada. Arct. Alp. Res. 10 (4), 749-760.

Anderson, R.S., Molnar, P., Kessler, M.A., 2006. Features of glacial valley profiles simply explained. J. Geophys. Res. Earth Surface 111, F01004.

Andrews, J.T., 1965. The corries of the northern Nain-Okak section of Labrador. Geogr. Bull. 7 (2), 129-136.

Andrews, J.T., 1971. Quantitative analysis of the factors controlling the distribution of corrie glaciers in Okoa Bay, East Baffin Island: (with particular reference to global radiation), in: Morisawa, M., (Ed.), Quantitative Geo-morphology: some aspects and applications. Proceedings of the 2nd. Geomorphology Symposium, Binghamton, State University of New York, pp 223-241.

Andrews, J.T., Barry, R.G., Drapier, L., 1970. An inventory of the present and past glacierization of Home Bay and Okoa Bay, east Baffin Island, NWT, Canada, and some climatic and paleoclimatic considerations. J. Glaciol. 9, 337-362.

Andrews, J.T., Dugdale, R.E., 1971. Late Quaternary glacial and climatic history of northern Cumberland Peninsula, Baffin Island, NWT, Canada. Part V: Factors affecting corrie glacierization in Okoa Bay. Quat. Res. 1, 532-551.

Andrews, J.T., LeMasurier, W.E., 1973. Rates of Quaternary glacial erosion and corrie formation, Marie Byrd Land, Antarctica. Geology 1 (2), 75-80.

Andrews, J.T., Miller, G.H., 1972. Quaternary History of Northern Cumberland Peninsula, Baffin Island, N. W. T., Canada: Part IV: Maps of the Present Glaciation Limits and Lowest Equilibrium Line Altitude for Northand South Baffin Island. Arct. Alp. Res. 4 (1). 45-59.

Aniya, M., Welch, R., 1981. Morphometric analyses of Antarctic cirques from photogrammetric measurements. Geogr. Ann. Ser. A Phys. Geogr. 63 (1/2), 41-53.

Ardelean, F., Török-Oance, M., Urdea, P., Onaca, A., 2011. Application of object based image analysis for glacial cirques detection. Case study: the Jarcu Mountains (Southern Carpathians). Forum geografic. Studii și cercetări de geografie și protecția mediului 10 (1), 2026.

Ardelean, F., Drăguţ, L., Urdea, P., Török-Oance, M., 2013. Variations in landform definition: a quantitative assessment of differences between five maps of glacial cirques in the Jarcu Mountains (Southern Carpathians, Romania). Area 45 (3), 348-357.

Atwood, W.W., 1909. Glaciation of the Uinta and Wasatch Mountains. United States. Geological Survey. United States Geological Survey Professional Paper 61, Government Printing Office, Washington.

Augustinus, P.C., 1999. Reconstruction of the Bulgobac glacial system, Pieman River basin, western Tasmania. Australian Geographical Studies 37 (1), 2436.

Barr, I.D., Spagnolo, M., 2013. Palaeoglacial and palaeoclimatic conditions in the NW Pacific, as revealed by a morphometric analysis of cirques upon the Kamchatka Peninsula. Geomorphology 192, 15-29.

Barr, I.D., Spagnolo, M., 2014. Testing the efficacy of the glacial buzzsaw: insights from the Sredinny Mountains, Kamchatka. Geomorphology 206, 230-238.

Barr, I.D., Spagnolo, M., 2015. Understanding controls on cirque floor altitudes: insights from Kamchatka. Geomorphology 248, 1-13.

Bashenina, N.V., 1971. O roli blokovoy morfotektoniki v oledenenii sovetskikh Karpat. Izvestiya Vsesoyuznogo Geograficheskogo Obshchestva, 103 (2), 166-170.

Bathrellos, G.D., Skilodimou, H.D., Maroukian, H., 2014. The Spatial Distribution of Middle and Late Pleistocene Cirques in Greece. Geogr. Ann. Ser. A Phys. Geogr. 96 (3), 323-338.

Battey, M.H., 1960. Geological factors in the development of Veslgjuv-Botn and Vesl-Skautbotn, in: W.V. Lewis (Ed.), Norwegian Cirque Glaciers. Royal Geographical Society Research Series 4, pp. 5-10.

Benn, D.I., 1989. Debris transport by Loch Lomond Readvance glaciers in Northern Scotland: Basin form and the withinvalley asymmetry of lateral moraines. J. Quat. Sci. 4 (3), 243-254.

Benn, D.I., Evans, D.J.A., 2010. Glaciers and Glaciation. Hodder Education, London.

Benn, D.I., Lehmkuhl, F. 2000. Mass balance and equilibrium-line altitudes of glaciers in high-mountain environments. Quat. Int. 65, 15-29.

Bennett, M., 1990. The cwms of Snowdonia: a morphometric analysis. Department of Geography Queen Mary and Westfield College Research Papers in Geography 2.

Bogen, J., 1996. Erosion rates and sediment yields of glaciers. Ann. Glaciol. 22, 48-52.

Boulton, G.S., 1996. Theory of glacial erosion, transport and deposition as a consequence of subglacial sediment deformation. J. Glaciol. 42, 43-62. 
Brocklehurst, S.H., Whipple, K.X., 2007. Response of glacial landscapes to spatial variations in rock uplift rate. J. Geophys. Res. Earth Surface 112, F02035.

Brook, M.S., Kirkbride, M.P., Brock, B.W., 2006. Cirque development in a steadily uplifting range: rates of erosion and long-term morphometric change in alpine cirques in the Ben Ohau Range, New Zealand. Earth Surf. Process. Landf. 31 (9), 1167-1175.

Brown, R.B., 1905. Cirques: a review. Bull. Americ. Geograph. Soc. 37, 86-91.

Brown, V.H., Evans, D.J.A., Vieli, A., Evans, I.S., 2013. The Younger Dryas in the English Lake District: reconciling geomorphological evidence with numerical model outputs. Boreas 42 (4), 1022-1042.

Brozović, N., Burbank, D.W., Meigs, A.J., 1997. Climatic limits on landscape development in the northwestern Himalaya. Science 276 (5312), 571-574.

Champagnac, J.D., Molnar, P., Sue, C., Herman, F., 2012. Tectonics, climate, and mountain topography. J. Geophys. Res. Solid Earth 117, B02403.

Chen, A., Tian, M., Zhao, Z., Qian, F., Yao, H., 2014. Macroscopic and microscopic evidence of Quaternary glacial features and ESR dating in the Daweishan Mountain area, Hunan, eastern China. Quat. Int. 333, 62-68.

Clapperton, C.M., 1971. Evidence of cirque glaciation in the Falkland Islands. J. Glaciol. 10 (58), 121-125 .

Clark, R., 1972. Periglacial landforms and landscapes in the Falkland Islands. Biuletyn Peryglacjalny 21, 33-50.

Clough, R. McK., 1974. The morphology and evolution of the Lakeland corries. Unpublished M. Phil, dissertation in Geography, Queen Mary College, University of London, England.

Clough, R. McK., 1977. Some aspects of corrie initiation and evolution in the English Lake District. Proc. Cumb. Geol. Soc. 3, 209-232.

Coleman, C.G., Carr, S.J., Parker, A.G., 2009. Modelling topoclimatic controls on palaeoglaciers: implications for inferring palaeoclimate from geomorphic evidence. Quat. Sci. Rev. 28 (3), 249-259.

Cook, S.J., Swift, D.A., 2012. Subglacial basins: Their origin and importance in glacial systems and landscapes. Earth Sci. Rev. 115 (4), 332-372.

Damiani, A.V., Pannuzi, L., 1987. La glaciazione pleistocenica nell'Appennino Laziale-Abruzzese. III nota: opportunità di precisazioni terminologiche, metodologiche ed introduzione di parametric morfometrici. Bollettino della Societa Geologica Italiana 105 (1985-86), 75-96.

Darwin, C.R., 1842. Notes on the effects produced by the ancient glaciers of Caernarvonshire, and on the boulders transported by floating ice. London, Edinburgh and Dublin Philosophical Magazine and Journal of Science 21, 180-188.

Davies, J.L., 1967. Tasmanian landforms and Quaternary climates, in: Jennings J.N., Mabbutt, J.A., (Eds.), Landform Studies from Australia and New Guinea. Australian National University Press, Canberra, pp. 125.

Davies, T.R., Warburton, J., Dunning, S.A., Bubeck, A.A., 2013. A large landslide event in a post-glacial landscape: rethinking glacial legacy. Earth Surf. Process. Landf. 38 (11), 1261-1268.
Davis, P.T., 1999. Cirques of the Presidential Range, New Hampshire, and surrounding alpine areas in the northeastern United States. Géog. Phys. Quatern. 53 (1), 25-45.

DeGraff, J.V., 1979. Numerical Analysis of Cirques in the Bear River Range, North-central Utah. Modern Geology 7, 43-51.

Delmas, M., Gunnell, Y., Calvet, M., 2014. Environmental controls on alpine cirque size. Geomorphology 206, 318-329.

Delmas, M., Gunnell, Y., Calvet, M., 2015. A critical appraisal of allometric growth among alpine cirques based on multivariate statistics and spatial analysis. Geomorphology 228, 637-652.

de Martonne, E., 1900. Contribution à l'étude de la période glaciaire dans les Karpates méridionales. Bull. Soc. Geol. Fr. 28 (3), 275-319.

de Martonne, E., 1901. Sur la formation des cirques. Annales de Géographie 10, 10-16.

Derbyshire, E., 1963. Glaciation of the lake St. Clair district, WestCentral Tasmania. The Australian Geographer 9 (2), 97110.

Derbyshire, E., Evans, I.S., 1976. The climatic factor in cirque variation, in: Derbyshire, E. (Ed.), Geomorphology and Climate. John Wiley \& Sons, Chichester, pp. 447-494.

Dort, W., 1962. Glaciation of the Coer d'Alene District, Idaho. Geol. Soc. Am. Bull. 73 (7), 889-906.

Egholm, D.L., Nielsen, S.B., Pedersen, V.K., Lesemann, J.E., 2009. Glacial effects limiting mountain height. Nature 460 , 884-887.

Eisank, C., Drăguţ, L., Götz, J., Blaschke, T., 2010. Developing a semantic model of glacial landforms for object-based terrain classification - the example of glacial cirques, in: Addink, E.A., Van Coillie, F.M.B. (Eds.), GEOBIAGeographic Object-Based Image Analysis. ISPRS Vol.No. XXXVIII-4/C7, pp. 1682-1777.

Embleton, C., Hamann, C., 1988. A comparison of cirque forms between the Austrian Alps and the Highlands of Britain. Z.Geomorphol. Supp. 70, 75-93.

Embleton, C., King, C.A.M., 1975. Glacial Geomorphology. Halsted Press, New York.

Ergenzinger, P., 1967. Die eiszeitliche Vergletscherung des Bayerischen Waldes. Eiszeitalter und Gegenwart 18, 152-168.

Evans, I.S., 1969. The geomorphology and morphometry of glacial and nival areas, in: Chorley, R.J., (Ed.) Water, earth and man. A synthesis of hydrology, geomorphology and socio-economic geography. Methuen, London, pp. 369380.

Evans, I.S., 1974. The geomorphometry and asymmetry of glaciated mountains (with special reference to the Bridge River District, British Columbia). Unpublished Ph.D. Dissertation, University of Cambridge.

Evans, I.S., 1977. World-Wide Variations in the Direction and Concentration of Cirque and Glacier Aspects. Geogr. Ann. Ser. A Phys. Geogr. 59 (3/4), 151-175.

Evans, I.S., 1990. Climatic effects on glacier distribution across the southern Coast Mountains, B.C., Canada. Ann. Glaciol. 14, 58-64.

Evans, I.S., 1994. Lithological and structural effects on forms of glacial erosion: cirques and lake basins, in: Robinson, D.A., Williams, R.B.G. (Eds.), Rock Weathering and 
Landform Evolution. John Wiley \& Sons Ltd., Chichester, pp. 455-472.

Evans, I.S., 1999. Was the cirque glaciation of Wales timetransgressive, or not? Ann. Glaciol. 28, 33-39.

Evans, I.S., 2006a. Allometric development of glacial cirque form: geological, relief and regional effects on the cirques of Wales. Geomorphology 80 (3), 245-266.

Evans, I.S., 2006b. Local aspect asymmetry of mountain glaciation: a global survey of consistency of favoured directions for glacier numbers and altitudes. Geomorphology 73 (1), 166-184.

Evans, I.S., 2008. Glacial erosion processes and forms: Mountain glaciation and glacier geography, in: Burt, T.P., Chorley, R.J., Brunsden, D., Cox, N.J., Goudie, A.S. (Eds.), The history of the study of landforms or the development of geomorphology. Vol. 4: Quaternary and Recent Processes and Forms (1890-1965) and the Mid-Century revolutions. The Geological Society of London, pp. 413494.

Evans, I.S., 2009. Allometric development of glacial cirques: an application of specific geomorphometry. In: Proceeding of Geomorphology, Zurich, Switzerland, 31 August - 2 September.

Evans, I.S., 2010. Allometry, scaling and scale-specificity of cirques, landslides and other

landforms. Transactions of the Japanese Geomorphological Union 31, 133-153.

Evans, I.S., 2012. Geomorphometry and landform mapping: What is a landform? Geomorphology 137 (1), 94-106.

Evans, I.S., Cox, N.J., 1974. Geomorphometry and the operational definition of cirques. Area 6, 150-153.

Evans, I.S., Cox, N.J., 1995. The form of glacial cirques in the English Lake District, Cumbria. Z. Geomorphol. 39, 175202.

Evans, I.S, Cox, N.J., 2005. Global variations of local asymmetry in glacier altitude: separation of north-south and eastwest components. J. Glaciol. 51, 469-482.

Evans, I.S., Hall, A., Kleman, J., 2015. Glacial cirques and the relationship between equilibrium line altitudes and mountain range height. Forum Comment, Geology 43 (6), 366.

Evans, I.S., McClean, C.J., 1995. The land surface is not unifractal: variograms, cirque scale and allometry. Z.Geomorphol. Supp. 101, 127-147.

Federici, P.R., Spagnolo, M., 2004. Morphometric analysis on the size, shape and areal distribution of glacial cirques in the Maritime Alps (Western French-Italian Alps). Geogr. Ann. Ser. A Phys. Geogr. 86 (3), 235-248.

Fey, M., Korr, C., Maidana, N.I., Carrevedo, M.L., Corbella, H., Dietrich, S., Haberzettl, T., Kuhn, G., Lücke, A., Mayr, C., Ohlendorf, C., Paez, M.M., Quintana, F.A., Schäbitz, F., Zolitschka, B., 2009. Palaeoenvironmental changes during the last 1600 years inferred from the sediment record of a cirque lake in southern Patagonia (Laguna Las Vizcachas, Argentina). Palaeogeog. Palaeoclim. Palaeoecol. 281 (3), 363-375.

Flint, RF., 1957. Glacial and Pleistocene Geology. Wiley \& Sons, New York.

Foster, D., Brocklehurst, S.H., Gawthorpe, R.L., 2008. Small valley glaciers and the effectiveness of the glacial buzzsaw in the northern Basin and Range, USA. Geomorphology 102, 624-639.

Fränzle, O., 1959. Glaciale und periglaciale Formbildung in Östlichen Kastilischen Scheidegebirge (Zentral spanien). Bonner geogr. Abh., Ht. 26.

Galibert, M.G., 1962. Recherches sur les processus d'érosion glaciaire de la Haute Montagne

Alpine. Bulletin de l'Association des Géographes Français 303, 846.

Galloway, R.W., 1963. Glaciation in the Snowy Mountains: a reappraisal. Proceedings of the Linnean Society of New South Wales 88 (2), 180-198.

García-Ruiz, J.M., Gómez-Villar, A., Ortigosa, L., Martí-Bono, C., 2000. Morphometry of glacial cirques in the Central Spanish Pyrenees. Geogr. Ann. Ser. A Phys. Geogr. 82 (4), 433-442.

Gardner, J.S., 1987. Evidence for headwall weathering zones, Boundary Glacier, Canadian

Rocky Mountains. J. Glaciol. 33, 60-67.

Gastaldi, B., 1873. On the effects of glacier-erosion in Alpine valleys. Quarterly Journal of the Geological Society 29 (1-2), 396-401.

Gâștescu, P., 1971. Lacurile din România; Limnologie regională. București, Editura Academiei Republicii Socialiste România.

Graf, W.L., 1976. Cirques as glacier locations. Arct. Alp. Res. 8, 79-90.

Grout, M., 1979. Amount and rate of Holocene cirque erosion, Northern Sangre de Cristo Mountains, Colorado. Geol. Soc. Am. Abstracts with Programs 11 (6), 273.

Godard, A., 1965. Recherches de géomorphologie en Écosse du Nord-Ouest. Paris, Les Belles Lettres.

Godard, V., Bourles, D.L., Spinabella, F., Burbank, D.W., Bookhagen, B., Fisher, G.B., Moulin, A., and Leanni, L., 2014, Dominance of tectonics over climate in Himalayan denudation. Geology 42 (3), 243-246.

Goldthwait, R.P., 1970. Mountain glaciers of the Pre-sidential Range in New Hampshire. Arct. Alp. Res. 2 (2), 85-102.

Gómez-Villar, A., Santos-González, J., González-Gutiérrez, R.B., Redondo-Vega, J.M., 2015. Glacial Cirques in the Southern Side of the Cantabrian Mountain of Southwestern Europe. Geogr. Ann. Ser. A Phys. Geogr. In press.

Gordon, J.E., 1977. Morphometry of cirques in the Kintail-AffricCannich area of northwest Scotland. Geogr. Ann. Ser. A Phys. Geogr. 59, 177-194.

Gordon, J.E., 2001. The corries of the Cairngorm Mountains. Scott. Geogr. Mag. 117 (1), 49-62.

Hall, A.M., Kleman, J., 2014. Glacial and periglacial buzzsaws: fitting mechanisms to metaphors. Quat. Res. 81, 189192.

Hallet, B., Hunter, L., Bogen, J., 1996. Rates of erosion and sediment evacuation by glaciers:

a review of field data and their implications. Global and Planet. Change 12 (1), 213-235.

Harker, A., 1901, Ice erosion in the Cuillin Hills, Skye. Trans. Roy. Soc. Edin. 40 (2), 221-252.

Hassinen, S., 1998. A morpho-statistical study of cirques and cirque glaciers in the Senja-Kilpisjärvi area, northern Scandinavia. Norsk Geografisk Tidsskrift-Norwegian Journal of Geography 52 (1), 27-36. 
Hättestrand, C., Kolka, V., Johansen, N., 2008. Cirque infills in the Khibiny Mountains, Kola Peninsula, Russiapalaeoglaciological interpretations and modern analogues in East Antarctica. J. Quat. Sci. 23 (2), 165174.

Haynes, V.M., 1968. The influence of glacial erosion and rock structure on corries in Scotland. Geogr. Ann. Ser. A Phys. Geogr. 50, 221-234.

Haynes, V.M., 1995. Alpine valley heads on the Antarctic Peninsula. Boreas 24 (1), 81-94.

Haynes, V.M., 1998. The morphological development of alpine valley heads in the Antarctic

Peninsula. Earth Surf. Process. Landf. 23, 53-67.

Helland, A., 1877. On the ice-fjords of North Greenland and on the formation of fjords, lakes, and cirques in Norway and Greenland. J.Geol. Soc. Lon. 33, 142-176.

Hicks, D.M., McSaveney, M.J., Chinn, T.J.H., 1990. Sedimentation in proglacial Ivory Lake, Southern Alps, New Zealand. Arct. Alp. Res. 22 (1), 26-42.

Holmlund, P., Näslund, J.O., 1994. The glacially sculptured landscape in Dronning Maud Land, Antarctica, formed by wet-based mountain glaciation and not by the present ice sheet. Boreas 23 (2), 139-148.

Hooke, R. Le B., 1991. Positive feedbacks associated with erosion of glacial cirques and overdeepenings. Geol. Soc. Am. Bull. 103, 1104-1108.

Hovius, N., Stark, C.P., 2006. Landslide-driven erosion and topographic evolution of active mountain belts, in: Evans, S.G., Mugnozza, G.S., Strom, A., Hermanns, R.L., (Eds.) Landslides from massive rock slope failure. NATO Science Series 49, Springer Netherlands. pp. 573-590.

Hubbard, B., Souness, C., Brough, S., 2014. Glacier-like forms on Mars. The Cryosphere 8, 2047-2061.

Hughes, P.D., Gibbard, P.L., Woodward, J.C., 2007. Geological controls on Pleistocene glaciation and cirque form in Greece. Geomorphology 88 (3), 242-253.

Hughes, P.D., Woodward, J.C., Gibbard, P.L., Macklin, M.G., Gilmour, M.A., Smith, G.R., 2006. The glacial history of the Pindus Mountains, Greece. J. Geol. 114, 413-434.

Ivanovskiy, L.N., 1965. Rasprostraneniye, morfologiya i proiskhozhdeniye Karov Altaya. Sibirskiy Geograficheskiy Sbornik, Tom 4, 152-198.

Iverson, N.R., 1991. Potential effects of subglacial water-pressure fluctuations on quarrying. J. Glaciol. 37 (125), 27-36.

Jansson, P., Richardson, C., Jonsson, S., 1999. Assessment of requirements for cirque formation in northern Sweden. Ann. Glaciol. 28, 16-22.

Jarman, D., 2002. Rock slope failure and landscape evolution in the Caledonian Mountains, as exemplified in the Abisko area, northern Sweden.Geogr. Ann. Ser. A Phys. Geogr.84 (3-4), 213-224.

Jarman, D., Calvet, M., Corominas, J., Delmas, M., Gunnell, Y., 2014. Large-Scale Rock Slope Failures in the Eastern Pyrenees: Identifying a Sparse But Significant Population in Paraglacial and Parafluvial Contexts. Geogr. Ann. Ser. A Phys. Geogr.96 (3), 357-391.

Johnson, W.D., 1904. The profile of maturity in alpine glacial erosion. Journal of Geology 12, 569-578. Reprinted in Embleton, C. (Ed.), 1972, Glaciers and Glacial Erosion. Macmillan, London, pp. 70-78.
Kargel, J.S., Strom, R.G., 1992. Ancient glaciation on Mars. Geology 20 (1), 3-7.

King. C.A.M., Gage, M., 1961. Notes on the extent of glaciation in parts of West Kerry. Irish Geography 4 (3), 202-208.

Kleman, J., Stroeven, A.P., 1997. Preglacial surface remnants and Quaternary glacial regimes in northwestern Sweden. Geomorphology 19 (1), 35-54.

Kornilov, B. A., 1964. Issledovaniya po marshrutu ot Oymyakonskogo ploskogorya do poberezhya Okhotskogo moray, in: Grave N.A., et al (ed.) Promerzaniye zemnoy poverkhnosti i oledeneniye Khrebta Suntar-Khayata (Vostochnaya Yakutiya). Moskva, Izdatelstvo 'Nauka' (Rezultaty issledovaniy po programme Mezhdunarodnogo Geofizicheskogo Goda. Glyatsiologiya. IX razdel programmy MGG 14, pp. 106115.

Krrížek, M., Mida, P., 2013. The influence of aspect and altitude on the size, shape and spatial

distribution of glacial cirques in the High Tatras (Slovakia, Poland). Geomorphology 198, 57-68.

Křížek, M., Vočadlová, K., Engel, Z., 2012. Cirque overdeepening and their relationship to morphometry. Geomorphology 139, 495-505.

Larsen, E., Mangerud, J., 1981. Erosion Rate of a Younger Dryas Cirque Glacier at Krakenes, Western Norway. Ann. Glaciol. 2 (1), 153-158.

Lewis, C.A., 1970. The glaciation of the Brecknock Beacons. Brycheiniog (The Brecknock Society) 14, 97-120.

Lewis, W.V., 1938. A melt-water hypothesis of cirque formation. Geol. Mag. 75, 249-265.

Lewis, W.V., 1949. Glacial movement by rotational slipping. Geogr. Ann. Ser. A Phys. Geogr.31, 146-158.

Lewis, W.V., 1960. The problem of cirque erosion, in: Lewis, W.V. (Ed.), Norwegian Cirque Glaciers, Royal Geographical Society Research Series 4, London, pp. 97-100.

Linton, D.L., 1959. Morphological contrasts between eastern and western Scotland, in: Miller, R., Watson, J.W., (Eds.). Geographical Essays in Memory of Alan G. Ogilvie. Nelson, Edinburgh, pp. 16-45.

Linton, D.L., 1963. The forms of glacial erosion. Trans.Inst. Brit. Geogr. 33, 1-28.

Locke, W.W.,1990. Late Pleistocene glaciers and the climate of western Montana, USA. Arct. Alp. Res. 22 (1), 1-13.

Löffler, E., 1972. Pleistocene glaciation in Papua and New Guinea. Zeitsch. für Geomorphology., Supplementband 13, 3258.

MacGregor, K.R., Anderson, R.S., Anderson, S.P., Waddington, E.D., 2000. Numerical simulations of glacial-valley longitudinal profile evolution. Geology 28 (11), 10311034.

MacGregor, K.R., Anderson, R.S., Waddington, E.D., 2009. Numerical modelling of glacial erosion and headwall processes in alpine valleys. Geomorphology 103, 189204.

Marinescu, E., 2007. The morphometry of the glacial cirques within the Gilort Basin. Analele Universităţii din Craiova. Seria Geografie 10, 5-12.

McDougall, D., 2013. Glaciation style and the geomorphological record: evidence for Younger Dryas glaciers in the eastern Lake District, northwest England. Quat. Sci. Rev. 73, 48-58. 
McLaren, P., Hills, L.V., 1973. Cirque analysis as a method of predicting the extent of a Pleistocene ice advance. Can. J. Earth Sci. 10 (8), 1211-1225.

Meierding, T.C., 1982. Late Pleistocene glacial equilibrium-line altitudes in the Colorado Front Range: a comparison of methods. Quat. Res. 18 (3), 289-310.

Mills, H.H., 1979. Some implications of sediment studies for glacial erosion on Mount Rainier, Washington. Northwest Science 53 (3), 190-199.

Mîndrescu, M., Evans, I.S., Cox, N.J., 2010. Climatic implications of cirque distribution in the Romanian Carpathians: palaeowind directions during glacial periods. J. Quat. Sci. $25(6), 875-888$.

Mîndrescu, M., Evans, I.S., 2014. Cirque form and development in Romania: allometry and the buzzsaw hypothesis. Geomorphology 208, 117-136.

Mitchell, S.G., Humphries, E.E., 2015. Glacial cirques and the relationship between equilibrium line altitudes and mountain range height. Geology 43 (1), 35-38.

Mitchell, S.G., Montgomery, D.R., 2006. Influence of a glacial buzzsaw on the height and morphology of the Cascade Range in central Washington State, USA. Quat. Res. 65 (1), 96-107.

Moller, J.J., Sollid, J.L., 1973. Geomorfologisk Kart over LofotenVesterålen. Norsk Geografisl Tidsskrift 27 (3), 195-205.

Mutch, A.R., 1963. Sheet 23 (Oamaru), Geological Map of New Zealand 1:250,000, 1st Edition. Wellington, New Zealand, Department of Scientific and Industrial Research.

Nelson, F.E., 1998. Cryoplanation terrace orientation in Alaska. Geogr. Ann. Ser. A Phys. Geogr.80 (2), 135-151.

Nelson, F.E.N., Jackson, L.E., Jr., 2003. Cirque forms and alpine glaciation during the Pleistocene, west-central Yukon, in: Emond, D.S., Lewis, L.L., (Eds.), Yukon Exploration and Geology 2, Exploration and Geological Services Division, Yukon Region, Indian and Northern Affairs Canada, pp. 183-198.

Niculescu, G., 1965. Muntii Godeanu: studiu geomor-fologic. București, Editura Academiei Republicii Populare Romîne.

Oberbeck, G., 1964. Ergebnisse natur- und kulturgeographischer Untersuchungen auf den Färöern. Beitrage zu einer Landerkunde. Jahrb. der Geogr. Ges. zu Hannover für die Jahre 1960 bis 1962, pp 13-150.

Olyphant, G.A., 1977. Topoclimate and the depth of cirque erosion. Geogr. Ann. Ser. A Phys. Geogr.59, 209-213.

Olyphant, G.A., 1981. Allometry and cirque evolution. Geol. Soc. Am. Bull. 92 (9), 679-685.

Oskin, M., Burbank, D.W., 2005. Alpine landscape evolution dominated by cirque retreat. Geology 33, 933-936.

$\varnothing$ strem, G., Haakensen, N., Eriksson, T., 1981. The glaciation level in southern Alaska. Geogr. Ann. Ser. A Phys. Geogr.63, 251-260.

Pelto, M.S., 1992. Equilibrium line altitude variations with latitude, today and during the Late Wisconsin. Palaeogeog. palaeoclim. palaeoecol. 95 (1), 41-46.

Peterson, J.A., Robinson G., 1969. Trend surface mapping of cirque floor levels. Nature 222, 75-76.

Péwé, T.L., Burbank, L., Mayo, L.R., 1967: Multiple glaciation of the Yukon-Tanana upland, Alaska. United States
Geological Survey. Miscellaneous Geologic Investigations Map 507, 1 sheet.

Pippan, T., 1967: Comparative glacio-morphological research in Alpine, Hercynian and Caledonian mountains of Europe, in: Sporck, J.A., (Ed.) Mdlangés de géographie offerts a M. Omer Tulippe, Vol. 1, Gembloux, Belgique, J. Duculot. pp 87-104.

Porter, S.C., 1964. Composite Pleistocene snow line of Olympic Mountains and Cascade Range, Washington. Geol. Soc. Am. Bull. 75 (5), 477-482.

Porter, S.C., 1989. Some geological implications of average Quaternary glacial conditions. Quat. Res. 32 (3), 245261.

Principato, S.M., Lee, J.F., 2014. GIS analysis of cirques on Vestfirðir, northwest Iceland: implications for palaeoclimate. Boreas 43, 807-817.

Reheis, M.J., 1975. Source, transportation and deposition of debris on Arapaho glacier, Front Range, Colorado, USA. J. Glaciol. 14 (7), 407-420.

Richter, D., 2006. Morphometric Analysis of Cirques in Fiordland. Unpublished Diploma, Dresden University of Technology, New Zealand.

Rose, K.C., Ferraccioli, F., Jamieson, S.S., Bell, R.E., Corr, H., Creyts, T.C., Braaten, D., Jordan, T.A., Fretwell, P.T., Damaske, D., 2013. Early east Antarctic Ice Sheet growth recorded in the landscape of the Gamburtsev Subglacial Mountains. Earth Planet. Sci. Lett. 375, 1-12.

Rudberg, S. 1952. Some observations on the geology and morphology of the Pältsa area. Särtryck ur Botaniska Notiser Supplement 3 (2), 14-44.

Rudberg, S., 1954. Västerbottens Berggrundsmorfologi. Geografica, Skrifter från Upsala Univ. Geogr. Inst., 25.

Rudberg, S., 1992. Multiple Glaciation in Scandinavia: Seen in Gross Morphology or Not? Geogr. Ann. Ser. A Phys. Geogr.74, 231-243.

Ruiz-Fernández, J., Pobleta-Piedrabuena, M.A., Serrano-Muela, M.P., Martí-Bono, C., García- Ruiz, J.M., 2009. Morphometry of glacial cirques in the Cantabrian Range (northwest Spain). Z. Geomorphol. 53, 47-68.

Sale, C., 1970. Cirque distribution in Great Britain: a statistical analysis of variations in elevation, aspect and density. Unpublished M.Sc. dissertation, Department of Geography, University College, London.

Salisbury, R.D., 1901. Glacial work in the western mountains in 1901. J. Geol. 9 (8), 718-731.

Sanders, J.W., Cuffey, K.M., Moore, J.R., MacGregor, K.R., Kavanaugh, J.L., 2012. Periglacial weathering and headwall erosion in cirque glacier bergschrunds. Geology 40 (9), 779-782.

Sanders, J.W., Cuffey, K.M., MacGregor, K.R., Collins, B.D., 2013. The sediment budget of an alpine cirque. Geol. Soc. Am. Bull. 125, 229-248.

Sauchyn, D.J., Cruden, D.M., Hu, X.Q., 1998. Structural control of the morphometry of open rock basins, Kananaskis region, Canadian Rocky Mountains. Geomorphology 22 (3), 313-324.

Sawicki, L. von., 1911, Die glazialen Züge der Rodnaer Alpen und Marmaroscher Karpaten. Mitt. der k.k. Geogr. Ges. zu Wien, Bd. 54, Ht. 10 and 11, 510-571. 
Scherler, D., 2014. Climatic limits to headwall retreat in the Khumbu Himalaya, eastern Nepal. Geology 42 (11), 1019-1022.

Scherler, D., Bookhagen, B., Strecker, M.R., 2011. Hillslopeglacier coupling: The interplay of topography and glacial dynamics in High Asia. J. Geophys. Res. Earth Surface 116, F02019.

Schmitz, H., 1969. Glazialmorphologische Untersuchungen im Bergland Nordwestspaniens (Gali-cien/León). Kolner Geogr. Arb., Ht. 23.

Schmidt-Thomé, P., 1973. Neue, niedrig gelegene Zeu-gen einer würm eiszeitlichen Vergletscherung im Nordteil der Iberischen Halbinsel (Prov. Vizcaya und Orense in Nordspanien: Minho-Distrikt in Nordportugal). Eiszeitalter und Gegenwart Bd. 23/24, 384-389.

Seddon, B., 1957. The late-glacial cwm glaciers in Wales. J. Glaciol. 3, 94-99.

Seif, A., Ebrahimi, B., 2014. Combined use of GIS and experimental functions for the morphometric study of glacial cirques, Zardkuh Mountain, Iran. Quat. Int. 353, 236-249.

Seijmonsbergen, A.C., Anders, N.S., Gabriner, R., Bouten, W., 2014. On the transferability of rule sets for mapping cirques using Object-based feature extraction. SouthEastern European Journal of Earth Observation and Geomatics 3 (2), 131-134.

Shakesby, R.A., Matthews, J.A., 1996. Glacial activity and paraglacial landsliding in the Devensian Lateglacial: evidence from Craig Cerrig-gleisiad and Fan Dringarth, Fforest Fawr (Brecon Beacons), South Wales. Geological Journal 31 (2), 143-157.

Sharp, R.P., 1960. Pleistocene glaciation of the Trinity Alps of Northern California. Am. J. Sci. 258, 305-340.

Sharp, R.P., Allen, C.R. Meier, M.F., 1959. Am. J. Sci. 257 (2), 8194.

Sissons, J.B., 1967. The evolution of Scotland's scenery. Oliver and Boyd, Edinburgh.

Soyez, D., 1974. Studien zur geomorphologie und zum Letztglazialen Eisrückzug in den Gebirgen Siid Lapplands, Schweden. Geogr. Ann. Ser. A Phys. Geogr.56, 1-71.

Spencer, K., 1959. Corrie aspect in the English Lake District. Don (Journal of the Sheffield University Geographical Society) 3, 6-9.

Steffanová, P., Mentlík, P., 2007. Comparison of morphometric characteristics of cirques in the Bohemian Forest. Silva Gabreta 13 (3), 191-204.

Stern, T.A., Baxter, A.K., Barrett, P.J., 2005. Isostatic rebound due to glacial erosion within the Transantarctic Mountains. Geology 33 (3), 221-224.

Sugden, D.E., 1969. The age and form of corries in the Cairngorms. Scott. Geogr. Mag. 85, 34-46.

Temple, P. H., 1965. Some aspects of cirque distribution in the west-central Lake District, northern England. Geogr. Ann. Ser. A Phys. Geogr.47, 185-193.

Thomson, S.N., Brandon, M.T., Tomkin, J.H., Reiners, P.W., Vásquez, C., Wilson, N.J., 2010. Glaciation as a destructive and constructive control on mountain building. Nature 467 (7313), 313-317.

Thorn, C.E., 1976. Quantitative evaluation of nivation in the Colorado Front Range. Geol. Soc. Am. Bull. 87, 11691178.
Thorn, C.E., 1988. Nivation: a geomorphic chimera, in: Clark, M.J. (Ed.), Advances in Periglacial Geomorphology, John Wiley, Chichester, 3-31.

Trenhaile, A.S., 1976. Cirque morphometry in the Canadian Cordillera. Ann. Assoc. Am. Geogr. 66, 451-462.

Turnbull, J.M., Davies, R.H., 2006. A mass movement origin for cirques. Earth Surf. Process. Landf. 31, 1129-1148.

Tyndall, J., 1862. On the conformation of the Alps. Philosophical Magazine 24 (160), 169-173.

Unwin, D. J., 1973: The distribution and orientation of corries in northern Snowdonia, Wales. Trans.Inst. Brit. Geogr. 58, 85-97.

Urdea, P., 2001. Glaciar relief and pleistocene glaciation in Retezat mountains (Transylvanians Alps, Romania). Geographica Pannonica 5, 4-7.

Valla, P.G., Shuster, D.L., van der Beek, P.A., 2011. Significant increase in relief of the European Alps during midPleistocene glaciations. Nat. Geosci. 4 (10), 688-692.

Vilborg, L., 1984. The cirque forms of central Sweden. Geogr. Ann. Ser. A Phys. Geogr. 66, 41-77.

Walder J.S, Hallet, B., 1986. The physical basis of frost weathering: toward a more fundamental and unified perspective. Arct. Alp. Res. 18, 27-32.

Ward, D., Anderson, R.S., Haeussler, P.J., 2012. Scaling the Teflon Peaks: rock type and the generation of extreme relief in the glaciated western Alaska Range. J. Geophys. Res. Earth Surface 117, F01031.

White, W.A., 1970. Erosion of cirques. J. Geol. 78, 123-126.

Williams, L.D., 1975. The variation of corrie elevation and equilibrium line altitude with aspect in eastern Baffin Island, NWT, Canada. Arct. Alp. Res. 7 (2), 169-181.

Wojciechowski, K.H., Wilgat, T., 1972. Mapa geologicznohydrograficzna dorzecza górnej Rio Aconcagua. Przeglad Geograficzny 14 (4), 635-648, plus 4 maps.

Zienert, A., 1967. Vogesen und Schwarzwald-Kare. Eiszeitalter und Gegenwart, Bd. 18, 51-57. 